\title{
Stille Reactions Catalytic in Tin: A Sn-F Route for Intermolecular and Intramolecular Couplings
}

\author{
William P. Gallagher and Robert E. Maleczka, Jr. \\ Department of Chemistry, Michigan State University, 540 Chemistry, East Lansing, MI 48824 \\ maleczka@cem.msu.edu
}

\section{Supporting Information \\ Table of Contents}

S2 Materials and Methods

S2-S3 Experimental Procedures for Scheme 2

S3-S4 Experimental Procedures for Scheme 3

S4-S9 Experimental Procedures for Table 1

S9-S10 Experimental Procedures for the Preparation of 10

S11-S12 Experimental Procedures for Preparation of 8 and 5

S12-S14 Experimental Procedures for Scheme 4

S14-S16 Experimental Procedures for Scheme 5 (Hydrostannation portion)

S16-S17 Control Experiment (Alternate preparation of 28)

S17-S18 Control Experiment (Alternate Preparation of 27)

S18-S21 Survey of Ligand Combinations and Conditions with a table (Scheme 5, a-h)

S22-S23 Experimental Procedures for Scheme 5 (entries I - L)

S24 Experimental Procedures for Table 2 
S24-S25 Control Experiment (Hydrostannation of alkyne 7)

S25-S27 Experimental Procedures for Scheme 7

S28-S29 Control Experiment (Procedures for the use of $\mathrm{Me}_{3} \mathrm{SnF}, \mathrm{Me}_{3} \mathrm{SnH}$ and vinylstannane $\mathbf{3 4}$ as the source of tin)

S30-S95 Copies of ${ }^{1} \mathrm{H}$ and ${ }^{13} \mathrm{C}$ Spectra

S96-S97 References and Notes

\section{Materials and Methods}

All air or moisture sensitive reactions were carried out in oven- or flame-dried glassware under a nitrogen atmosphere unless otherwise noted. All commercial reagents were used without purification. All solvents were reagent grade. Diethyl ether and THF were freshly distilled from sodium/benzophenone under nitrogen. Except as otherwise noted, all reactions were magnetically stirred and monitored by thin-layer chromatography with $0.25-\mathrm{mm}$ precoated silica gel plates or capillary GC with a fused silica column. Flash chromatography was performed with

silica gel $60 \AA$ (particle size 230-400 mesh ASTM). Yields refer to chromatographically and spectroscopically pure compounds unless otherwise stated. The reported melting points are uncorrected. Chemical shifts for ${ }^{1} \mathrm{H}$ NMR and ${ }^{13} \mathrm{C}$ NMR are reported in parts per million (ppm) relative to $\mathrm{CDCl}_{3}\left(\delta=7.24 \mathrm{ppm}\right.$ for ${ }^{1} \mathrm{H}$ NMR or $\delta=77.0 \mathrm{ppm}$ for $\left.{ }^{13} \mathrm{C} \mathrm{NMR}\right)$. GC/MS were performed with a fused silica column ( $30 \mathrm{~m}$ by $0.25 \mathrm{~mm}$ i.d.).

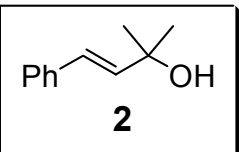

Initial Tin Catalyzed Stille Reaction with $\mathrm{Bu}_{3} \mathrm{SnH}$ : The "Sn-F" Approach. Procedure for the preparation of $(E)$-2-methyl-4-phenylbut-3-en-2-ol (2)

(Scheme 2). Tri-2-furylphosphine (2.3 mg, $0.01 \mathrm{mmol})$ was added to a solution of $\mathrm{Pd}_{2} \mathrm{dba}_{3}(3.7$ $\mathrm{mg}, 0.004 \mathrm{mmol})$ in THF $(5 \mathrm{~mL})$. After stirring at room temperature for $15 \mathrm{~min}$, 2-methyl-3- 
butyn-2-ol ( $0.1 \mathrm{~mL}, 1 \mathrm{mmol})$, iodobenzene $(0.17 \mathrm{~mL}, 1.5 \mathrm{mmol}), \mathrm{Bu}_{3} \mathrm{SnCl}(16 \mu \mathrm{L}, 0.06 \mathrm{mmol})$, PMHS $(0.09 \mathrm{~mL}, 1.5 \mathrm{mmol})$ and aq. $\mathrm{KF}\left(0.1743 \mathrm{~g}, 3 \mathrm{mmol} ; 1 \mathrm{~mL} \mathrm{H} \mathrm{H}_{2} \mathrm{O}\right)$ were added to the solution. The solution was allowed to reflux for $48 \mathrm{~h}$. The organics were separated, washed with brine, dried $\left(\mathrm{MgSO}_{4}\right)$ and concentrated. The resulting residue was purified by flash chromatography [silica gel; 90/10 pentane/ EtOAc] to afford (E)-2-methyl-4-phenylbut-3-en-2-ol (2) $(34 \mathrm{mg}, 21 \%)^{1}$ as a clear oil. ${ }^{1} \mathrm{H}$ NMR $\left(300 \mathrm{MHz}, \mathrm{CDCl}_{3}\right) \delta 1.42(\mathrm{~s}, 6 \mathrm{H}), 1.69(\mathrm{br} \mathrm{s}, 1 \mathrm{H})$, $6.35(\mathrm{~d}, J=15.9 \mathrm{~Hz}, 1 \mathrm{H}), 6.58(\mathrm{~d}, J=15.9 \mathrm{~Hz}, 1 \mathrm{H}), 7.18-7.43(\mathrm{~m}, 5 \mathrm{H}) ;{ }^{13} \mathrm{C} \mathrm{NMR}(75 \mathrm{MHz}$, $\left.\mathrm{CDCl}_{3}\right) \delta 25.0,66.2,121.5,121.6,122.6,123.7,132.1,132.7$.

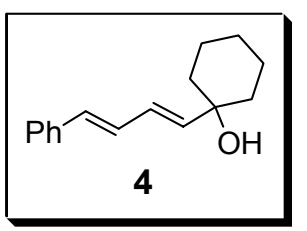

Representative procedure for the tin loading experiments. Preparation of 1-((1E,3E)-4-phenylbuta-1,3-dienyl)cyclohexanol (4), use of $4 \mathrm{~mol} \%$ $\mathrm{Me}_{3} \mathrm{SnCl}$ (Scheme 3). Following the general procedure below using $\mathrm{Me}_{3} \mathrm{SnCl}(0.04 \mathrm{~mL}$ of a $1 \mathrm{M}$ solution in THF, $0.04 \mathrm{mmol})$, 1-ethynyl-cyclohexanol (3) (124 mg, $1 \mathrm{mmol})$ and $E$ - $\beta$-bromostyrene $(275 \mathrm{mg}, 1.5 \mathrm{mmol})$ after column chromatography [silica gel; 90:10 hexane/EtOAc] 1-(4-phenyl-buta-1,3-dienyl)-cyclohexanol (4) (144 mg, 63\%) as an oil. IR $\left(\mathrm{CHCl}_{3}\right) 3594,2938,2859,2402,1703,1597,1491,1451,1350,1125,992,909 \mathrm{~cm}^{-1} ;{ }^{1} \mathrm{H}$ NMR $\left(300 \mathrm{MHz}, \mathrm{CDCl}_{3}\right) \delta 1.21-1.77(\mathrm{~m}, 10 \mathrm{H}), 5.92(\mathrm{~d}, J=15.4 \mathrm{~Hz}, 1 \mathrm{H}), 6.42(\mathrm{dd}, J=15.4$, $10.4 \mathrm{~Hz}, 1 \mathrm{H}), 6.53$ (d, $J=15.4 \mathrm{~Hz}, 1 \mathrm{H}), 6.75$ (dd, $J=15.4,10.4 \mathrm{~Hz}, 1 \mathrm{H}), 7.19-7.38$ (m, $5 \mathrm{H})$;

${ }^{13} \mathrm{C}$ NMR $\left(75 \mathrm{MHz}, \mathrm{CDCl}_{3}\right) \delta 22.0,25.4,37.8,71.6,126.2,127.4,127.6,128.5,128.8,132.0$, 137.3, 141.7; HRMS (EI) $m / z 228.1519$ [(M) calcd. for $\mathrm{C}_{16} \mathrm{H}_{20} \mathrm{O}$ 228.1514].

Preparation of 1-((1E,3E)-4-phenylbuta-1,3-dienyl)cyclohexanol (4), use of $2 \mathrm{~mol} \%$ $\mathrm{Me}_{3} \mathrm{SnCl}$ (Scheme 3). Following the general procedure below using $\mathrm{Me}_{3} \mathrm{SnCl}(0.02 \mathrm{~mL}$ of a 1 M solution in THF, $0.02 \mathrm{mmol})$, 1-ethynyl-cyclohexanol (3) $(124 \mathrm{mg}, 1 \mathrm{mmol})$ and $E-\beta-$ bromostyrene $(275 \mathrm{mg}, 1.5 \mathrm{mmol})$ after column chromatography [silica gel; 90:10 
hexane/EtOAc] 1-(4-phenyl-buta-1,3-dienyl)-cyclohexanol (4) (89 $\mathrm{mg}, 39 \%)$ as an oil. For spectroscopic data see above.

Preparation of 1-((1E,3E)-4-phenylbuta-1,3-dienyl)cyclohexanol (4), use of 1 mol \% $\mathrm{Me}_{3} \mathrm{SnCl}$ (Scheme 3). Following the general procedure below using $\mathrm{Me}_{3} \mathrm{SnCl}(0.01 \mathrm{~mL}$ of a 1 M solution in THF, $0.01 \mathrm{mmol})$, 1-ethynyl-cyclohexanol (3) (124 mg, $1 \mathrm{mmol})$ and $E-\beta-$ bromostyrene (275 mg, $1.5 \mathrm{mmol})$ after column chromatography [silica gel; 90:10 hexane/EtOAc] 1-(4-phenyl-buta-1,3-dienyl)-cyclohexanol (4) (43 mg, 19\%) as an oil. For spectroscopic data see above.

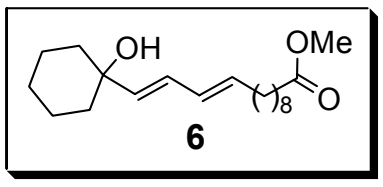

Representative procedure for the tandem one pot hydrostannation/Stille coupling with $6 \mathrm{~mol} \% \mathrm{Me}_{3} \mathrm{SnCl}$ using the "Sn-F" route. Preparation of 13-(1-hydroxy-cyclohexyl)-trideca-10,12-dienoic acid methyl ester (6) (Table 1, entry 1). Tri-2-furylphosphine (9.3 $\mathrm{mg}, 0.04 \mathrm{mmol})$ was added to a solution of $\mathrm{Pd}_{2} \mathrm{bda}_{3}(9.2 \mathrm{mg}, 0.01 \mathrm{mmol})$ in $\mathrm{Et}_{2} \mathrm{O}(5 \mathrm{~mL})$. After stirring at room temperature for $15 \mathrm{~min}$, (E)-11-iodo-undec-10-enoic acid methyl ester (5, see below for preparation) (486.3 $\mathrm{mg}, 1.5$ mmol), $\mathrm{Me}_{3} \mathrm{SnCl}(0.06 \mathrm{~mL}, 0.06 \mathrm{mmol}$; $1 \mathrm{M}$ solution in THF), aq. $\mathrm{KF}(0.1743 \mathrm{~g}, 3 \mathrm{mmol} ; 1 \mathrm{~mL}$ $\left.\mathrm{H}_{2} \mathrm{O}\right)$, TBAF $(0.8 \mu \mathrm{L}$ of a $1 \mathrm{M}$ solution in THF, $0.008 \mathrm{mmol})$ and $\mathrm{PdCl}_{2}\left(\mathrm{PPh}_{3}\right)_{2}(7.0 \mathrm{mg}, 0.01$ mmol) were all added to the solution. The solution was heated to reflux and then a solution of 1ethynyl-cyclohexanol (3) (124.2 mg, $1.0 \mathrm{mmol})$ and PMHS (0.09 mL, $1.5 \mathrm{mmol})$ in $\mathrm{Et}_{2} \mathrm{O}(4 \mathrm{~mL})$ was added via a syringe pump over $11 \mathrm{hrs}$. The phases were separated and the organics washed with brine, dried over $\mathrm{MgSO}_{4}$, filtered and concentrated. The residue was purified by flash chromatography [silica gel; 90:10 hexane/EtOAc] 13-(1-hydroxy-cyclohexyl)-trideca-10,12dienoic acid methyl ester (6) (235 mg, 73\%) as an oil. IR(neat) $3356,1774 \mathrm{~cm}^{-1} ;{ }^{1} \mathrm{H}$ NMR (300 $\left.\mathrm{MHz}, \mathrm{CDCl}_{3}\right) \delta 1.21-1.38(\mathrm{~m}, 11 \mathrm{H}), 1.42-1.68(\mathrm{~m}, 12 \mathrm{H}), 2.03(\mathrm{q}, J=7.51 \mathrm{~Hz}, 2 \mathrm{H}), 2.26(\mathrm{t}, J=$ 
$7.29 \mathrm{~Hz}, 2 \mathrm{H}), 3.70(\mathrm{~s}, 3 \mathrm{H}), 5.65(\mathrm{~m}, 2 \mathrm{H}), 5.99(\mathrm{dd}, J=10.38,15.02 \mathrm{~Hz}, 1 \mathrm{H}) ; 6.19(\mathrm{dd}, J=$ $10.38,15.46 \mathrm{~Hz}, 1 \mathrm{H}) ;{ }^{13} \mathrm{C}\left(75 \mathrm{MHz}, \mathrm{CDCl}_{3}\right) \delta 22.1,24.9,25.5,29.1,29.1,29.2,29.2,29.2,32.5$,

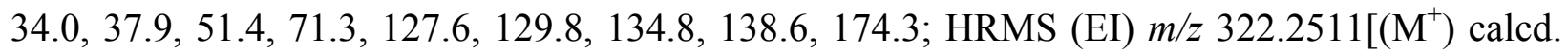
for $\mathrm{C}_{20} \mathrm{H}_{34} \mathrm{O}_{3}$ 322.2508].

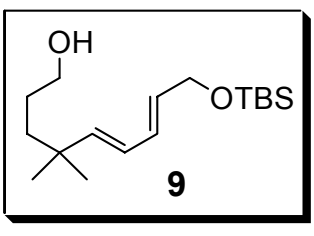

Preparation of 9-(tert-butyl-dimethyl-silanyloxy)-4,4-dimethyl-nona5,7-dien-1-ol (9) (Table 1, entry 2). Applying the above conditions to 4,4dimethyl-hex-5-yn-1-ol (32) (0.1262 g, 1 mmol) and (E)-(3-iodo-allyloxy)tert-butyl-dimethyl-silane (8) (0.4470 g, $1.5 \mathrm{mmol})$ afforded after column chromatography [silica gel; 80:20 hexane/EtOAc] 9-(tert-butyl-dimethyl-silanyloxy)-4,4-dimethyl-nona-5,7-dien-1-ol (9) $(63 \mathrm{mg}, 43 \%)$ as an oil. IR (neat) $3348 \mathrm{~cm}^{-1} ;{ }^{1} \mathrm{H} \mathrm{NMR}\left(500 \mathrm{MHz}, \mathrm{CDCl}_{3}\right) \delta 0.06(\mathrm{~s}, 6 \mathrm{H})$, 0.90 (s, 9 H), 1.00 (s, 6 H), 1.30-1.35 (m, 2 H), 1.43-1.52 (m, 2 H), 1.55 (br s, 1 H), 3.57 (t, $J=$ $6.52 \mathrm{~Hz}, 2 \mathrm{H}), 4.18$ (dd, $J=1.44,5.30 \mathrm{~Hz}, 2 \mathrm{H}), 5.59$ (d, $J=15.02 \mathrm{~Hz}, 1 \mathrm{H}), 5.65$ (dt, $J=5.30$, $15.24 \mathrm{~Hz}, 1 \mathrm{H}), 5.94(\mathrm{dd}, J=10.38,15.57 \mathrm{~Hz}, 1 \mathrm{H}), 6.17(\mathrm{dd}, J=10.38,15.24,1 \mathrm{H}) ;{ }^{13} \mathrm{C}(125$ $\left.\mathrm{MHz}, \mathrm{CDCl}_{3}\right) \delta$-5.2, 18.4, 25.9, 27.2, 28.1, 35.7, 38.9, 63.5, 63.6, 125.9, 130.3, 130.5, 143.8; HRMS (EI) m/z 298.2331 [( $\left.\mathrm{M}^{+}\right)$calcd. for $\mathrm{C}_{17} \mathrm{H}_{34} \mathrm{O}_{2} \mathrm{Si}$ 298.2328].

Preparation of 9-(tert-butyl-dimethyl-silanyloxy)-4,4-dimethyl-nona-5,7-dien-1-ol (9) (Table 1, entry 3). Applying the above conditions to 4,4-dimethyl-hex-5-yn-1-ol (32) (0.1262 g, 1 $\mathrm{mmol}$ ) and (E)-(3-bromo-allyloxy)-tert-butyl-dimethyl-silane (10) (0.3754 g, $1.5 \mathrm{mmol})$ afforded after column chromatography [silica gel; 80:20 hexane/EtOAc] afforded 9-(tert-butyl-dimethylsilanyloxy)-4,4-dimethyl-nona-5,7-dien-1-ol (9) (105 mg, 72\%) as an oil.

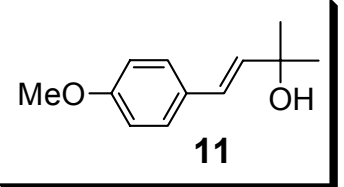

Preparation of 4-(4-methoxy-phenyl)-2-methyl-but-3-en-2-ol (11)

(Table 1, entry 4). Applying the above conditions to 2-methyl-but-3-yn2-ol (1) $(0.10 \mathrm{~mL}, 1.0 \mathrm{mmol})$ and $p$-iodoanisole $(351.1 \mathrm{mg}, 1.5 \mathrm{mmol})$, 
afforded after column chromatography [silica gel; 90:10 hexane/EtOAc] 4-(4-methoxy-phenyl)2-methyl-but-3-en-2-ol (11) (198mg, 78\%) as an oil. ${ }^{2}$

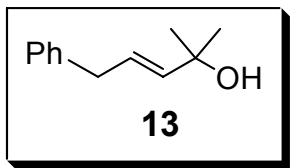

Preparation of 2-methyl-5-phenyl-pent-3-en-2-ol (13) (Table 1, entry 6). Applying the above conditions to 2-methyl-but-3-yn-2-ol (1) $(0.10 \mathrm{~mL}, 1.0$ mmol) and benzyl bromide $(0.18 \mathrm{~mL}, 1.5 \mathrm{mmol})$ afforded after column chromatography [silica gel; 90:10 hexane/EtOAc] 2-methyl-5-phenyl-pent-3-en-2-ol (13) (149 mg, 85\%) as an oil. ${ }^{3}$

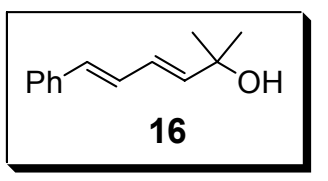

Preparation of 2-methyl-6-phenyl-hexa-3,5-dien-2-ol (16) (Table 1, entry

9). Applying the above conditions to 2-methyl-but-3-yn-2-ol (1) $(0.10 \mathrm{~mL}, 1$

$\mathrm{mmol}$ ) and (E)- $\beta$-bromostyrene (274.5 $\mathrm{mg}, 1.5 \mathrm{mmol})$, afforded after column chromatography [silica gel, 90:10 hexane/EtOAc] 2-methyl-6-phenyl-hexa-3,5-dien-2-ol (16) (165 mg, 88\%) as an oil. IR $\left(\mathrm{CHCl}_{3}\right) 3598,3451 \mathrm{~cm}^{-1} ;{ }^{1} \mathrm{H}$ NMR $\left(300 \mathrm{MHz}, \mathrm{CDCl}_{3}\right) \delta 1.31(\mathrm{~s}, 6 \mathrm{H}), 5.86(\mathrm{~d}, J=$ 15.4 Hz, $1 \mathrm{H}$ ), 6.38 (ddd, $J=15.4,10.4,0.6 \mathrm{~Hz}, 1 \mathrm{H}), 6.53$ (d, $J=15.7 \mathrm{~Hz}, 1 \mathrm{H}), 6.76$ (ddd, $J=$ 15.7, 10.4, 0.6 Hz, $1 \mathrm{H}), 7.16-7.39(\mathrm{~m}, 5 \mathrm{H}) ;{ }^{13} \mathrm{C} \mathrm{NMR}\left(75 \mathrm{MHz}, \mathrm{CDCl}_{3}\right) \delta$ 29.8, 77.0, 126.2, 127.3, 127.8, 128.5, 128.6, 131.9, 137.2, 140.8; HRMS (EI) $m / z 188.1204\left[(\mathrm{M})^{+}\right.$calcd for $\mathrm{C}_{13} \mathrm{H}_{16} \mathrm{O}$ 188.1201].

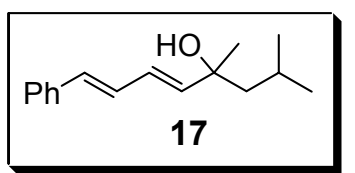

Preparation of 2,4-dimethyl-8-phenyl-octa-5,7-dien-4-ol (17) (Table 1, entry 10). Applying the above conditions to 3,5-dimethyl-hex-1-yn-3-ol $(0.15 \mathrm{~mL}, 1.0 \mathrm{mmol})$ and $(E)-\beta$-bromostyrene $(274.5 \mathrm{mg}, 1.5 \mathrm{mmol})$, afforded after column chromatography [silica gel; 90:10 hexane/EtOAc] 2,4-dimethyl-8-phenyl-octa-5,7-dien-4-ol (17) (205 mg, 89\%) as an oil. IR $\left(\mathrm{CHCl}_{3}\right) 3594,2955 \mathrm{~cm}^{-1} ;{ }^{1} \mathrm{H} \mathrm{NMR}\left(300 \mathrm{MHz}, \mathrm{CDCl}_{3}\right) \delta 0.92(\mathrm{~d}, J$ $=4.7 \mathrm{~Hz}, 3 \mathrm{H}), 0.94(\mathrm{~d}, J=4.4 \mathrm{~Hz}, 3 \mathrm{H}), 1.33(\mathrm{~s}, 3 \mathrm{H}), 1.50(\mathrm{~d}, J=6.0 \mathrm{~Hz}, 2 \mathrm{H}), 1.76(\mathrm{~m}, 1 \mathrm{H})$, $5.88(\mathrm{~d}, J=15.4 \mathrm{~Hz}, 1 \mathrm{H}), 6.39(\mathrm{dd}, J=15.4,10.4 \mathrm{~Hz}, 1 \mathrm{H}), 6.53(\mathrm{~d}, J=15.7 \mathrm{~Hz}, 1 \mathrm{H}), 6.76(\mathrm{dd}$, $J=15.7,10.4 \mathrm{~Hz}, 1 \mathrm{H}), 7.22-7.39(\mathrm{~m}, 5 \mathrm{H}) ;{ }^{13} \mathrm{C} \mathrm{NMR}\left(75 \mathrm{MHz}, \mathrm{CDCl}_{3}\right) \delta 24.4,24.6,29.1,51.4$, 
73.6, 126.2, 127.2, 127.3, 128.5, 128.6, 131.8, 137.3, 141.6; HRMS (EI) $m / z 212.1570$ [(M $\left.\mathrm{H}_{2} \mathrm{O}\right)^{+}$calcd. for $\mathrm{C}_{16} \mathrm{H}_{20} 212.1565$.

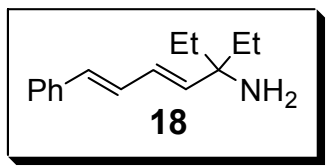

\section{Preparation of 1,1-diethyl-5-phenyl-penta-2,4-dienylamine (18) (Table}

1, entry 11). Applying the above conditions to 1,1-diethyl-prop-2ynylamine $(0.10 \mathrm{~mL}, 1.0 \mathrm{mmol})$ and $(E)-\beta$-bromostyrene $(274.5 \mathrm{mg}, 1.5 \mathrm{mmol})$, afforded after column chromatography [silica gel; 60:40 hexane/EtOAc] 1,1-diethyl-5-phenyl-penta-2,4dienylamine (18) (163 mg, 82\%) as an oil. IR $\left(\mathrm{CHCl}_{3}\right) 3180,2934 \mathrm{~cm}^{-1} ;{ }^{1} \mathrm{H}$ NMR $(300 \mathrm{MHz}$, $\left.\mathrm{CDCl}_{3}\right) \delta 0.84(\mathrm{t}, J=7.4 \mathrm{~Hz}, 6 \mathrm{H}), 1.33(\mathrm{br}, 2 \mathrm{H}), 1.48(\mathrm{q}, J=7.4 \mathrm{~Hz}, 4 \mathrm{H}), 5.74(\mathrm{~d}, J=15.4 \mathrm{~Hz}$ $1 \mathrm{H}), 6.28(\mathrm{dd}, J=15.4,10.4 \mathrm{~Hz}, 1 \mathrm{H}), 6.49(\mathrm{~d}, J=15.7 \mathrm{~Hz}, 1 \mathrm{H}), 6.78(\mathrm{dd}, J=15.6,10.3 \mathrm{~Hz}, 1$ H), 7.15-7.38 (m, $5 \mathrm{H}) ;{ }^{13} \mathrm{C}$ NMR $\left(75 \mathrm{MHz}, \mathrm{CDCl}_{3}\right) \delta 8.1,34.0,56.3,126.1,127.1,128.1,128.6$, 129.1, 130.9, 137.5, 142.4; HRMS (EI) $m / z 198.1411\left(\mathrm{M}-\mathrm{NH}_{3}\right)^{+}$calcd. for $\mathrm{C}_{15} \mathrm{H}_{18} 198.1409$.

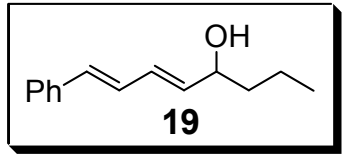

Preparation of 8-phenyl-octa-5,7-dien-4-ol (19) (Table 1, entry 12). Applying the above conditions to hex-1-yn-3-ol $(0.12 \mathrm{~mL}, 1.0 \mathrm{mmol})$ and (E)- $\beta$-bromostyrene $(274.5 \mathrm{mg}, 1.5 \mathrm{mmol})$ afforded after column chromatography [silica gel; 90:10 hexane/EtOAc] 8-phenyl-octa-5,7-dien-4-ol (19) (117 mg, 60\%) as an oil. IR (neat) 3352 $\mathrm{cm}^{-1} ;{ }^{1} \mathrm{H}$ NMR $\left(300 \mathrm{MHz}, \mathrm{CDCl}_{3}\right) \delta 0.98(\mathrm{t}, J=7.2 \mathrm{~Hz}, 3 \mathrm{H}), 1.34-1.72(\mathrm{~m}, 4 \mathrm{H}), 1.81(\mathrm{br} \mathrm{s}, 1$ H), $4.24(\mathrm{q}, J=6.5 \mathrm{~Hz}, 1 \mathrm{H}), 5.85(\mathrm{dd}, J=6.9,15.6 \mathrm{~Hz}, 1 \mathrm{H}), 6.41(\mathrm{dd}, J=10.4,15.3 \mathrm{~Hz}, 1 \mathrm{H})$, $6.57(\mathrm{~d}, J=15.7 \mathrm{~Hz}, 1 \mathrm{H}), 6.80(\mathrm{dd}, J=10.4,15.6 \mathrm{~Hz}, 1 \mathrm{H}), 7.21-7.49(\mathrm{~m}, 5 \mathrm{H}){ }^{13} \mathrm{C}$ NMR $(75$ $\left.\mathrm{MHz}, \mathrm{CDCl}_{3}\right) \delta 13.9,18.5,39.5,72.5,126.3,127.5,128.3,128.6,130.5,132.5,136.8,137.1$ HRMS (EI) $\mathrm{m} / \mathrm{z} 202.1349\left[\left(\mathrm{M}^{+}\right)\right.$calcd. for $\left.\mathrm{C}_{14} \mathrm{H}_{18} \mathrm{O} 202.1358\right]$.

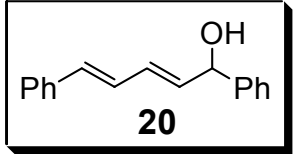

Preparation of 1,5-diphenyl-penta-2,4-dien-1-ol (20) (Table 1, entry 13). Applying the above conditions to 1-phenyl-prop-2-yn-1-ol $(0.13 \mathrm{~mL}, 1.0$ $\mathrm{mmol})$ and $(E)$ - $\beta$-bromostyrene $(274.5 \mathrm{mg}, 1.5 \mathrm{mmol})$ afforded after column chromatography 
[silica gel; 90:10 hexane/EtOAc] 1,5-diphenyl-penta-2,4-dien-1-ol (20) (137 mg, 68\%) as an oil. ${ }^{1} \mathrm{H}$ NMR $\left(300 \mathrm{MHz}, \mathrm{CDCl}_{3}\right) \delta 5.34(\mathrm{~d}, J=7.1 \mathrm{~Hz}, 1 \mathrm{H}), 6.03(\mathrm{dd}, J=7.1,15.1 \mathrm{~Hz}, 1 \mathrm{H}), 6.50$ (dd, $J=10.4,15.1 \mathrm{~Hz}, 1 \mathrm{H}), 6.60(\mathrm{~d}, J=15.9 \mathrm{~Hz}, 1 \mathrm{H}), 6.81(\mathrm{dd}, J=10.4,15.5 \mathrm{~Hz}, 1 \mathrm{H}), 7.11-$ $7.47(\mathrm{~m}, 10 \mathrm{H}) ;{ }^{13} \mathrm{C}$ NMR $\left(75 \mathrm{MHz}, \mathrm{CDCl}_{3}\right) \delta 74.9,126.3,126.4,127.6,127.7,128.2,128.6$, $130.9,133.2,135.5,137.0$; whose spectroscopic data was consistent with those reported earlier. ${ }^{4}$ Preparation of 6-phenyl-hexa-3,5-dien-1-ol (21) (Table 1, entry 14): Applying the above

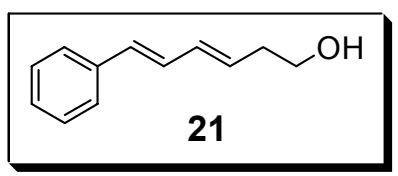
conditions to 3-butyn-1-ol $(0.08 \mathrm{ml}, 1.0 \mathrm{mmol})$, and $(E)-\beta-$ bromostyrene $(1.5 \mathrm{mmol}, 274.5 \mathrm{mg})$ in diethyl ether $(4 \mathrm{~mL})$ afford after column chromatography [silica gel; 80:20 pentane/EtOAc, 1\% Et ${ }_{3} \mathrm{~N}$ ] 6-phenyl-hexa-3,5-dien-1ol (30) $(60 \mathrm{mg}, 34 \%)$ as a white solid $\left(\mathrm{mp}=63-64{ }^{\circ} \mathrm{C}\right) . \quad \mathrm{IR}\left(\mathrm{CHCl}_{3}\right) 3435 \mathrm{~cm}^{-1} ;{ }^{1} \mathrm{H}$ NMR $(300$ $\left.\mathrm{MHz}, \mathrm{CDCl}_{3}\right) \delta 2.45(\mathrm{q}, J=7.2 \mathrm{~Hz}, 2 \mathrm{H}) 3.75(\mathrm{t}, J=6.6 \mathrm{~Hz}, 2 \mathrm{H}), 5.82(\mathrm{dt}, J=7.2,15.4 \mathrm{~Hz}, 1$ H), $6.35(\mathrm{dd}, J=10.4,15.4 \mathrm{~Hz}, 1 \mathrm{H}), 6.51(\mathrm{~d}, J=15.9 \mathrm{~Hz}, 1 \mathrm{H}), 6.79(\mathrm{dd}, J=10.4,15.9 \mathrm{~Hz}, 1$ H), 7.17-7.53 (m, $5 \mathrm{H}) ;{ }^{13} \mathrm{C}$ NMR $\left(75 \mathrm{MHz}, \mathrm{CDCl}_{3}\right) \delta 36.2,65.8,126.2,127.3,128.5,128.7$, 130.7, 131.2, 133.4, 137.3; HRMS (EI) $m / z$ 174.1039 [( $\left(\mathrm{M}^{+}\right)$calcd. for $\mathrm{C}_{12} \mathrm{H}_{14} \mathrm{O}$ 174.1045].

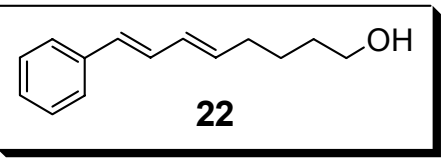

Preparation of 8-phenyl-octa-5,7-dien-1-ol (22) (Table 1, entry 15). Applying the above conditions to 6-bromo-hex-5-yn-1-ol ${ }^{5}$ $(0.13 \mathrm{~mL}, 1.0 \mathrm{mmol})$ and $(E)-\beta$-bromostyrene $(274.5 \mathrm{mg}, 1.5 \mathrm{mmol})$ afforded after column chromatography [silica gel; 80:20 hexane/EtOAc] 8-phenyl-octa-5,7-dien-1-ol (22) (123 mg, $61 \%)$ as a white solid. $\left(\mathrm{mp}=38.6{ }^{\circ} \mathrm{C}\right):{ }^{1} \mathrm{H} \operatorname{NMR}\left(500 \mathrm{MHz}, \mathrm{CDCl}_{3}\right) \delta 1.51(\mathrm{~m}, 2 \mathrm{H}), 1.61(\mathrm{~m}, 2$ H), 1.73 (br s, $1 \mathrm{H}), 2.19$ (q, $J=7.9 \mathrm{~Hz}, 2 \mathrm{H}), 3.65$ (t, $J=6.6 \mathrm{~Hz}, 2 \mathrm{H}), 5.83(\mathrm{dt}, J=7.5,15.5 \mathrm{~Hz}$ $1 \mathrm{H}), 6.23(\mathrm{dd}, J=10.4,15.9 \mathrm{~Hz} 1 \mathrm{H}), 6.46(\mathrm{~d}, J=15.9 \mathrm{~Hz}, 1 \mathrm{H}), 6.76(\mathrm{dd}, J=10.2,15.7 \mathrm{~Hz} 1$ $\mathrm{H})$, 7.14-7.46 (m, $5 \mathrm{H}) ;{ }^{13} \mathrm{C} \mathrm{NMR}\left(125 \mathrm{MHz}, \mathrm{CDCl}_{3}\right) \delta 137.5,135.2,130.9,130.2,129.3,128.5$, 
$127.1,126.1,62.7,32.5,32.2,25.3$. Spectroscopic data was consistent with those reported earlier. $^{6}$

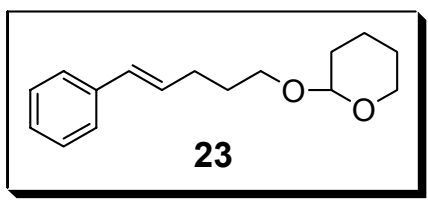

Preparation of 2-((E)-5-phenylpent-4-enyloxy)-tetrahydro-2Hpyran (23) (Table 1, entry 16). Applying the above conditions to

2-(5-bromopent-4-ynyloxy)-tetrahydro-2H-pyran ${ }^{5}(246 \mathrm{mg}, 1.0 \mathrm{mmol})$ and iodobenzene $(0.15$ $\mathrm{mL}, 1.5 \mathrm{mmol})$ afforded after column chromatography [silica gel; 80:20 hexane/EtOAc] 2-((E)5-phenylpent-4-enyloxy)-tetrahydro-2H-pyran (23) (128 mg, 52\%) as an oil. ${ }^{1} \mathrm{H}$ NMR (300 $\left.\mathrm{MHz}, \mathrm{CDCl}_{3}\right) \delta 1.49-1.89(\mathrm{~m}, 8 \mathrm{H}), 2.31(\mathrm{dt}, J=7.1,7.1 \mathrm{~Hz}, 2 \mathrm{H}), 3.41(\mathrm{dt}, J=9.6,6.5 \mathrm{~Hz}, 1 \mathrm{H})$, $3.5(\mathrm{~m}, 1 \mathrm{H}), 3.74(\mathrm{dt}, J=6.8,9.6 \mathrm{~Hz}, 1 \mathrm{H}), 3.85(\mathrm{~m}, 1 \mathrm{H}), 4.60(\mathrm{t}, J=3.5 \mathrm{~Hz}, 1 \mathrm{H}), 6.24(\mathrm{dt}, J=$ $6.615 .8 \mathrm{~Hz}, 1 \mathrm{H}), 6.41(\mathrm{~d}, J=15.8 \mathrm{~Hz}, 1 \mathrm{H}), 7.15-7.40(\mathrm{~m}, 5 \mathrm{H}) ;{ }^{13} \mathrm{C} \mathrm{NMR}\left(75 \mathrm{MHz}, \mathrm{CDCl}_{3}\right) \delta$ $19.6,25.4,29.3,29.4,30.7,62.3,66.9,98.8,125.9,126.8,128.4,130.1,130.3,137.7$. Spectroscopic data was consistent with those reported earlier. ${ }^{7}$

$\mathrm{Bu}_{3} \mathrm{Sn} \curvearrowright \mathrm{OH}_{\mathrm{OH}}$ Preparation of vinyl halides 8 and 10. Procedure for the preparation of 3-tributylstannanyl-prop-2-en-1-ol (Table 1). To $50 \mathrm{~mL}$ of THF was added $\mathrm{PdCl}_{2}\left(\mathrm{PPh}_{3}\right)_{2}$ (0.0702 g, $10 \mathrm{mmol})$, propargyl alcohol $(0.582 \mathrm{~mL}, 10 \mathrm{mmol}), \mathrm{Bu}_{3} \mathrm{SnCl}(3.25 \mathrm{~mL}, 12 \mathrm{mmol}), \mathrm{KF}$ (1.743 g, $30 \mathrm{mmol} ; 33 \mathrm{~mL} \mathrm{H} \mathrm{H}_{2}$ ), PMHS (0.9 mL, $15 \mathrm{mmol}$ ), and TBAF (2 drops of a $1 \mathrm{M}$ solution in THF, ca. $0.8 \mathrm{~mol} \%$ ). This mixture was then stirred for 1 hour. The reaction was then separated and the aqueous phase extracted with $\mathrm{Et}_{2} \mathrm{O}(2 \mathrm{x})$. The combined organics were then washed with Brine, dried over $\mathrm{MgSO}_{4}$, filtered, and concentrated. The resulting residue was purified by column chromatography [silica gel; 90:10 hexane/EtOAc, $1 \% \mathrm{NEt}_{3}$ ] to afford $(E)-3-$ tributylstannanyl-prop-2-en-1-ol ${ }^{8}(2.25 \mathrm{~g}, 65 \%)$ as a clear oil.

\begin{tabular}{|l|l}
$\mathrm{Bu}_{3} \mathrm{Sn} \curvearrowright$ & PTBS \\
\hline
\end{tabular} stannanyl-allyloxy)-silane (Table 1). $\mathrm{TBSCl}(1.86 \mathrm{~g}, 12.32 \mathrm{mmol})$ was added to a cooled (0 
$\left.{ }^{\circ} \mathrm{C}\right)$ solution of afford $(E)$-3-tributylstannanyl-prop-2-en-1-ol (4.50 g, $\left.13 \mathrm{mmol}\right)$, imidazole (1.10 g, $15.6 \mathrm{mmol})$, DMAP $(0.16 \mathrm{~g}, 1.3 \mathrm{mmol})$ in $\mathrm{CH}_{2} \mathrm{Cl}_{2}(25 \mathrm{~mL})$. The mixture was stirred until complete by TLC ( $\sim 40 \mathrm{~min})$. When complete the reaction was washed with brine, dried over $\mathrm{MgSO}_{4}$, filtered and concentrated. The resulting residue was purified by column chromatography [silica gel; hexane, $\left.1 \% \mathrm{NEt}_{3}\right]$ to afford (E)-tert-butyl-dimethyl-(3tributylstannanyl-allyloxy)-silane $(5.70 \mathrm{~g}, 95 \%)$ as clear liquid. ${ }^{9}$

$\mathrm{Br} \sim$ OTBS

10
Procedure for the preparation of (3-bromo-allyloxy)-tert-butyl-dimethyl-

silane (10) (Table 1). $N$-Bromosuccinimide (1.83 g, $10.24 \mathrm{mmol})$ was added

to a cold solution of (E)-tert-butyl-dimethyl-(3-tributylstannanyl-allyloxy)-silane (4.50 g, 9.75 mmol) in dry $\mathrm{CH}_{2} \mathrm{Cl}_{2}(50 \mathrm{~mL})$. When the reaction was complete (TLC, $1 \mathrm{hr}$ ), the reaction was quenched by the addition of sat. aq. $\mathrm{Na}_{2} \mathrm{~S}_{2} \mathrm{O}_{3}(25 \mathrm{~mL}) . \mathrm{CH}_{2} \mathrm{Cl}_{2}$ was added and the aqueous phase extracted with $\mathrm{CH}_{2} \mathrm{Cl}_{2}(3 \mathrm{X})$. The combined organics were washed with brine, dried over $\mathrm{Na}_{2} \mathrm{SO}_{4}$, filtered, and concentrated. The resulting residue was purified by column chromatography [silica gel; hexanes] to afford (E)-(3-bromo-allyloxy)-tert-butyl-dimethylsilane $^{10}$ (10) (2.43 g, 99\%) as a clear liquid. IR (neat) 2957, $2858 \mathrm{~cm}^{-1} ;{ }^{1} \mathrm{H}$ NMR (300 MHz, $\left.\mathrm{CDCl}_{3}\right) \delta 0.09(\mathrm{~s}, 6 \mathrm{H}), 0.92(\mathrm{~s}, 9 \mathrm{H}), 4.14(\mathrm{~m}, 2 \mathrm{H}), 6.30(\mathrm{~m}, 2 \mathrm{H}) ;{ }^{13} \mathrm{C}\left(75 \mathrm{MHz}, \mathrm{CDCl}_{3}\right) \delta-5.4$, 18.3, 25.8, 63.3, 106.1, 136.7; HRMS (EI) $\mathrm{m} / \mathrm{z} 250.0387\left[\left(\mathrm{M}^{+}\right)\right.$calcd. for $\mathrm{C}_{9} \mathrm{H}_{19} \mathrm{BrOSi}$ 250.0389].

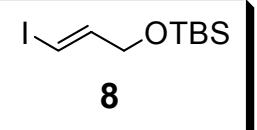

(E)-tert-butyl-dimethyl-(3-tributylstannanyl-allyloxy)-silane $(5.7 \mathrm{~g}, 12.4 \mathrm{mmol})$ in $\operatorname{dry~} \mathrm{CH}_{2} \mathrm{Cl}_{2}$ $(20 \mathrm{~mL})$. When the reaction was complete (TLC, $1 \mathrm{hr}$ ), the reaction was quenched by the addition of sat. aq. $\mathrm{Na}_{2} \mathrm{~S}_{2} \mathrm{O}_{3}(25 \mathrm{~mL}) . \mathrm{CH}_{2} \mathrm{Cl}_{2}$ was added and the aqueous phase extracted with 
$\mathrm{CH}_{2} \mathrm{Cl}_{2}(3 \mathrm{X})$. The combined organics were washed with Brine, dried over $\mathrm{Na}_{2} \mathrm{SO}_{4}$, filtered and concentrated. The resulting residue was purified by column chromatography [silica gel; hexanes] to afford (E)-(3-iodo-allyloxy)-tert-butyl-dimethyl-silane (8) $(0.32 \mathrm{~g}, 90 \%)$ as a clear liquid. ${ }^{11}$

IV $\mathrm{Y}_{8}^{\mathrm{CO}_{2} \mathrm{Me}}$

5

Preparation $^{12}$ of $(E)$-11-iodo-undec-10-enoic acid methyl ester (5). Methyl 10-undecenoate $(10.0 \mathrm{~g}, 50.42 \mathrm{mmol})$ was dissolved in a 2:1 $\mathrm{CH}_{2} \mathrm{Cl}_{2} / \mathrm{MeOH}$

solution $(200 \mathrm{~mL})$ with $1 \mathrm{~mL}$ of $\mathrm{NEt}_{3}$ added. The solution was purged with $\mathrm{N}_{2}$ for $15 \mathrm{~min}$. and then cooled to $-78{ }^{\circ} \mathrm{C}$. $\mathrm{O}_{3}$ was then bubbled through the solution until a blue color persisted $(\sim 1.5 \mathrm{~h})$. At this time, $\mathrm{N}_{2}$ was bubbled through the solution until the blue color disappeared. Dimethyl sulfide (15 mL, $202 \mathrm{mmol}$ ) was added dropwise and the solution was allowed to warm to room temperature overnight $(\sim 8 \mathrm{~h})$. The solvent was then concentrated and the resulting residue was purified by column chromatography [silica gel; 80:20 hexanes/EtOAc] to afford 10oxo-decanoic acid methyl ester (8.96 g, 90\%) as a clear liquid. Under an Ar atmosphere, TMSCl $(15.3 \mathrm{~mL}, 120 \mathrm{mmol})$ was added to a suspension of $\mathrm{CrCl}_{3}(0.6334 \mathrm{~g}, 4 \mathrm{mmol}), \mathrm{Zn}(7.84 \mathrm{~g}, 120$ $\mathrm{mmol})$, and $\mathrm{NaI}(3.0 \mathrm{~g}, 20 \mathrm{mmol})$ in dioxane $(100 \mathrm{~mL})$ at $25^{\circ} \mathrm{C}$. After the reaction was stirred for $40 \mathrm{~min}$, a solution of 10-oxo-decanoic acid methyl ester (4.01 g, $20 \mathrm{mmol})$ and $\mathrm{CHI}_{3}(15.75$ g, $40 \mathrm{mmol})$ in dioxane $(50 \mathrm{~mL})$ was added at $25^{\circ} \mathrm{C}$ via a syringe pump over 24 hours. After the addition the mixture became very thick. The reaction was quenched by the addition of water. The reaction was then extracted with hexanes $(5 \mathrm{X})$. The combined organics were washed with brine, dried over $\mathrm{MgSO}_{4}$, filtered, and concentrated. The resulting residue was purified by column chromatography [silica gel; 100:0 to 95:5 hexanes/EtOAc] to afford (E)-11-iodo-undec-

10-enoic acid methyl ester $(\mathbf{5})^{13}(12.14 \mathrm{~g}, 63 \%)$ as a peach colored liquid. ${ }^{1} \mathrm{H}$ NMR $(300 \mathrm{MHz}$, $\left.\mathrm{CDCl}_{3}\right) \delta$ 1.14-1.40 (m, $\left.10 \mathrm{H}\right), 1.45-1.62(\mathrm{~m}, 2 \mathrm{H}), 1.98(\mathrm{q}, J=6.94 \mathrm{~Hz}, 2 \mathrm{H}), 2.24(\mathrm{t}, \mathrm{J}=7.42$ 
$\mathrm{Hz}, 2 \mathrm{H}), 3.60$ (s, $3 \mathrm{H}), 5.92(\mathrm{dt}, J=1.40,14.34 \mathrm{~Hz}, 1 \mathrm{H}), 6.44(\mathrm{dt}, J=7.14,14.34 \mathrm{~Hz}, 1 \mathrm{H}) ;{ }^{13} \mathrm{C}$ $\left(75 \mathrm{MHz}, \mathrm{CDCl}_{3}\right) \delta 24.8,28.3,28.8,29.0,29.1,29.1,34.2,35.9,51.3,74.4,146.6,174.4$.

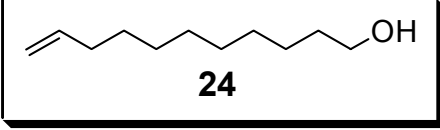

Procedure for the reduction of Ethyl undecylenate. Preparation of undec-10-en-1-ol (24) (Scheme 4). Ethyl undecylenate (25

mmol, $5.31 \mathrm{~g})$ was dissolved in $\mathrm{CH}_{2} \mathrm{Cl}_{2}(150 \mathrm{ml})$ and cooled to $-78{ }^{\circ} \mathrm{C}$ and flushed with $\mathrm{N}_{2}$. DIBAL (62.5 mmol, $62.5 \mathrm{~mL}$ of a $1 \mathrm{M}$ in THF) was added dropwise via an addition funnel and the mixture was then stirred for $3 \mathrm{hrs}$ at $-78^{\circ} \mathrm{C}$. The reaction was quenched by the addition of Rochelle's Salt (300 mL, sat aq.) and then allowed to warm to room temperature for $\sim 3 \mathrm{hrs}$. The phases are then separated and the aqueous phase was then extracted with $\mathrm{CH}_{2} \mathrm{Cl}_{2}(3 \mathrm{X})$. Organics were then combined, dried over $\mathrm{MgSO}_{4}$, filtered, and concentrated. The resulting residue was the purified by column chromatography [silica gel; 80:20 hexane/EtOAc] to afford $4.30 \mathrm{~g} \mathrm{(96 \% )}$ of undec-10-en-1-ol (24) (compared with commercial material).

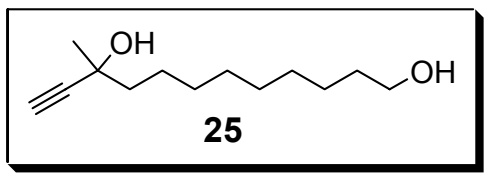

Preparation of 10-methyl-dodec-11-yne-1,10-diol (25) (Scheme 4). Using Uemura's ${ }^{14}$ method, pyridine (3.53 mmol, $0.29 \mathrm{~mL}$ ) was added to a mixture of $\mathrm{Pd}(\mathrm{OAc})_{2}(0.89 \mathrm{mmol}, 0.1978 \mathrm{~g})$ and toluene $(88 \mathrm{~mL})$ in a 3 neck flask equipped with an $\mathrm{O}_{2}$ balloon. $\mathrm{O}_{2}$ was introduced into the flask and 2-propanol $(17.62 \mathrm{~mL})$ was added and the mixture heated to $60{ }^{\circ} \mathrm{C}$ with an oil bath. After the reaction had been left for $5 \mathrm{~min}$ at $60{ }^{\circ} \mathrm{C}$, undec-10-en-1-ol (24) $(17.62 \mathrm{mmol}, 3.00 \mathrm{~g})$ in 2-propanol (71 $\left.\mathrm{mL}, 4 \mathrm{~mL} / 1 \mathrm{mmol}\right)$ and the reaction was stirred for 25 hours at $60{ }^{\circ} \mathrm{C}$ under $\mathrm{O}_{2}$. When complete, the reaction was concentrated and the resulting residue was purified by column chromatography [silica gel; 75:25 hexane/EtOAc] to afford 11-hydroxyundecan-2-one $(3.05 \mathrm{~g}, 85 \%)$ as a white solid (mp $\left.39{ }^{\circ} \mathrm{C}\right) .{ }^{14}$

To a $0{ }^{\circ} \mathrm{C}$ solution of ethynylmagnesium bromide $(37.66 \mathrm{mmol}, 76 \mathrm{~mL}$ of a $1 \mathrm{M}$ THF solution) was added 11-hydroxyundecan-2-one (16.37 mmol, $3.05 \mathrm{~g})$ in $150 \mathrm{~mL}$ of THF. This 
mixture was stirred for 1 hour after the addition and then was quenched by the addition of $100 \mathrm{ml}$ of sat. aq. $\mathrm{NH}_{4} \mathrm{Cl}$. The phases were separated and the aqueous phase was extracted with $\mathrm{Et}_{2} \mathrm{O}$. The organics were combined, dried over $\mathrm{MgSO}_{4}$, filtered, and concentrated. The resulting residue was purified by column chromatography [silica gel; 50:50 hexane/EtOAc] to afford 10methyl-dodec-11-yne-1,10-diol (25) (2.94 g, 85\%) as a thick yellow oil. IR (neat) $3304 \mathrm{~cm}^{-1} ;{ }^{1} \mathrm{H}$ NMR (300 MHz, CDCl 3$) \delta 1.20-1.68(\mathrm{~m}, 19 \mathrm{H}), 2.41(\mathrm{~s}, 1 \mathrm{H}), 2.54(\mathrm{br} \mathrm{s}, 2 \mathrm{H}), 3.60(\mathrm{t}, J=6.7$ $\mathrm{Hz}, 2 \mathrm{H}),{ }^{13} \mathrm{C} \mathrm{NMR}\left(75 \mathrm{MHz}, \mathrm{CDCl}_{3}\right) \delta 24.4,25.6,29.2,29.3,29.4,29.6,32.6,43.4,62.7,67.9$, 71.0, 87.8; HRMS (EI) $m / z 212.1771\left[\left(\mathrm{M}^{+}\right)\right.$calcd. for $\left.\mathrm{C}_{13} \mathrm{H}_{24} \mathrm{O}_{2} 212.1776\right]$.

Procedure for the DCC coupling. Preparation of 2-iodo-benzoic acid 10-hydroxy-10methyl-dodec-11-ynyl ester (26) (Scheme 4). To $285 \mathrm{~mL}$ of $\mathrm{CH}_{2} \mathrm{Cl}_{2}$ was added 2-iodobenzoic acid (7.44 g, 30 mmol), 10-methyl-dodec-11-yne-1,10-diol (25) (5.31 g, 25 mmol), DCC (30 mL of $1 \mathrm{M}$ solution in $\left.\mathrm{CH}_{2} \mathrm{Cl}_{2}, 30 \mathrm{mmol}\right)$ and then DMAP $(0.61 \mathrm{~g}, 5 \mathrm{mmol})$. This mixture was stirred for $8 \mathrm{~h}$ at room temperature. The reaction was then filtered through a bed a celite and then the celite cake was washed with $\mathrm{CH}_{2} \mathrm{Cl}_{2}(3 \mathrm{X})$. The filtrate was concentrated and purified by column chromatography [silica gel; 85:15 hexane/EtOAc] to afford 2-iodo-benzoic acid 10-hydroxy-10methyl-dodec-11-ynyl ester (26) (9.64 g, 88\%) as an oil and diester adduct (26-b) (170 mg, 1.5 \%) as an oil.

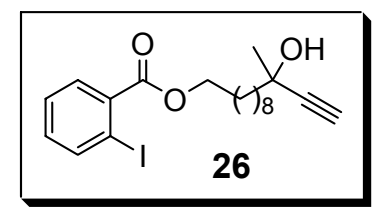

Data for the mono ester (26): IR (neat) 3443, 3302, $1726 \mathrm{~cm}^{-1} ;{ }^{1} \mathrm{H}$ NMR $\left(300 \mathrm{MHz}, \mathrm{CDCl}_{3}\right) \delta 1.15-1.56(\mathrm{~m}, 15 \mathrm{H}), 1.60-1.72(\mathrm{~m}, 2 \mathrm{H}), 1.73-1.86$ (m, $2 \mathrm{H}), 2.08$ (br s, $1 \mathrm{H}), 2.44$ (s, $1 \mathrm{H}), 4.34$ (t, $J=6.5 \mathrm{~Hz}, 2 \mathrm{H}), 7.15$ (td, $J=1.7,8.0 \mathrm{~Hz}, 1 \mathrm{H}), 7.41(\mathrm{td}, J=1.3,8.5 \mathrm{~Hz}, 1 \mathrm{H}), 7.79(\mathrm{dd}, J=1.2,7.4 \mathrm{~Hz}, 1 \mathrm{H}), 7.99(\mathrm{~d}, J=$ $8.0 \mathrm{~Hz}, 1 \mathrm{H}) ;{ }^{13} \mathrm{C}\left(75 \mathrm{MHz}, \mathrm{CDCl}_{3}\right) \delta 24.5,25.9,28.5,29.1,29.3,29.4,29.6,29.7,43.4,65.8$, 
67.9, 71.2, 87.7, 93.9, 127.8, 130.8, 132.4, 135.4, 141.1, 166.6; HRMS (EI) $m / z 442.1010\left[\left(\mathrm{M}^{+}\right)\right.$ calcd. for $\left.\mathrm{C}_{20} \mathrm{H}_{27} \mathrm{IO}_{3} 442.1005\right]$.

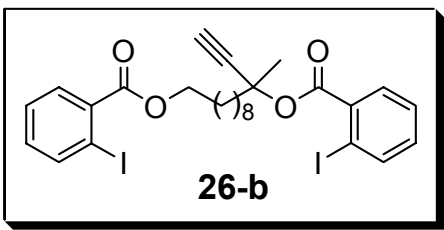

Data for diester (26-b): IR (neat) 3300, $1734 \mathrm{~cm}^{-1} ;{ }^{1} \mathrm{H}$ NMR (300 $\left.\mathrm{MHz}, \mathrm{CDCl}_{3}\right) \delta 1.18-1.66(\mathrm{~m}, 12 \mathrm{H}), 1.70-1.89(\mathrm{~m}, 5 \mathrm{H}), 1.90-2.20$ $(\mathrm{m}, 2 \mathrm{H}), 2.65(\mathrm{~s}, 1 \mathrm{H}), 4.34(\mathrm{t}, J=6.5 \mathrm{~Hz}, 2 \mathrm{H}), 7.08-7.20(\mathrm{~m}, 2 \mathrm{H})$, 7.35-7.45 (m, $2 \mathrm{H}), 7.72-7.83(\mathrm{~m}, 2 \mathrm{H}), 7.94-8.03(\mathrm{~m}, 2 \mathrm{H}) ;{ }^{13} \mathrm{C}\left(75 \mathrm{MHz}, \mathrm{CDCl}_{3}\right) \delta 24.1,26.0$, $26.4,28.5,29.1,29.3,29.4,41.3,65.8,73.9,76.7,83.5,93.7,93.9,127.8,127.8,130.7,130.8$, 132.3, 132.4, 135.4, 135.8, 141.1, 141.2, 164.8, 166.6; HRMS (EI) $m / z 672.0224\left[\left(\mathrm{M}^{+}\right)\right.$calcd. for $\left.\mathrm{C}_{27} \mathrm{H}_{30} \mathrm{I}_{2} \mathrm{O}_{4} 672.0234\right]$.
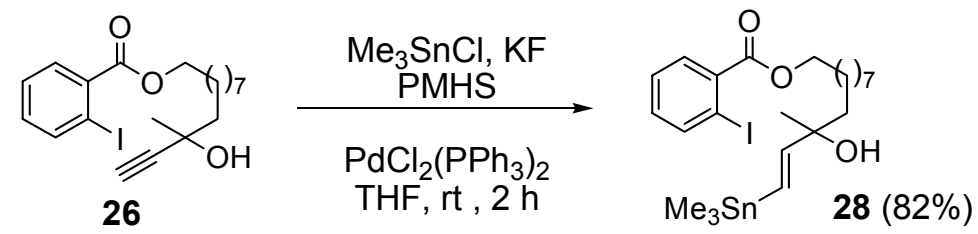

Procedure for the KF/PMHS hydrostannation of an alkyne in the presence of an aryl iodide. Preparation of 2-iodo-benzoic acid 10-hydroxy-10-methyl-12-trimethyl stannanyl-dodec-11enyl ester (28) (Scheme 5). To $10 \mathrm{~mL}$ of THF were added $\mathrm{Me}_{3} \mathrm{SnCl}(1.2 \mathrm{~mL}$ of a $1 \mathrm{M} \mathrm{THF}$ solution, $1.2 \mathrm{mmol}), \mathrm{KF}$ (175 mg, $3.0 \mathrm{mmol}), 1 \mathrm{~mL}$ of water, PMHS (0.08 mL, $1.2 \mathrm{mmol})$, $\mathrm{PdCl}_{2}\left(\mathrm{PPh}_{3}\right)_{2}(7.0 \mathrm{mg}, 0.01 \mathrm{mmol})$ and 2-iodo-benzoic acid 10-hydroxy-10-methyl-dodec-11ynyl ester (26) (442 mg, $1.0 \mathrm{mmol}$ ). This mixture was stirred at room temperature for $2 \mathrm{~h}$. The mixture was then washed with water and separated. The combined organics were dried $\left(\mathrm{MgSO}_{4}\right)$, filtered, and concentrated. The resulting residue was purified by column chromatography [silica gel; 90:10 hexane/EtOAc, 1\% TEA] to afford 2-iodo-benzoic acid 10hydroxy-10-methyl-12-trimethylstannanyl-dodec-11-enyl ester (28) (500 mg, 82\%) as an oil. IR 
(neat) $3387 \mathrm{~cm}^{-1} ;{ }^{1} \mathrm{H}$ NMR $\left(300 \mathrm{MHz}, \mathrm{CDCl}_{3}\right) \delta 0.14(\mathrm{~m}, 9 \mathrm{H}), 1.20-1.60(\mathrm{~m}, 18 \mathrm{H}), 1.79(\mathrm{~m}, 2$ H), $4.34(\mathrm{t}, J=6.7 \mathrm{~Hz}, 2 \mathrm{H}), 6.03(\mathrm{~d}, J=19.3 \mathrm{~Hz}, 1 \mathrm{H}), 6.17(\mathrm{~d}, J=19.0 \mathrm{~Hz}, 1 \mathrm{H}), 7.15(\mathrm{tt}, J=$ 1.7, 7.9, $1 \mathrm{H}), 7.41(\mathrm{tt}, J=1.2,7.6,1 \mathrm{H}), 7.79(\mathrm{dt}, J=1.4,7.8,1 \mathrm{H}), 7.99(\mathrm{dt}, J=1.2,7.9,1 \mathrm{H})$; ${ }^{13} \mathrm{C}$ NMR $\left(75 \mathrm{MHz}, \mathrm{CDCl}_{3}\right) \delta$-9.6, 23.8, 25.9, 27.6, 28.5, 29.2, 29.4, 29.4, 29.9, 42.2, 65.8, 74.4, 93.9, 124.1, 127.8, 130.8, 132.4, 135.5, 141.2, 154.2, 166.6; HRMS (EI) $m / z 593.0563\left[\left(\mathrm{M}^{+}-\mathrm{CH}_{3}\right)\right.$ calcd. for $\left.\mathrm{C}_{22} \mathrm{H}_{34} \mathrm{IO}_{3} \mathrm{Sn}\right] 593.0579$.
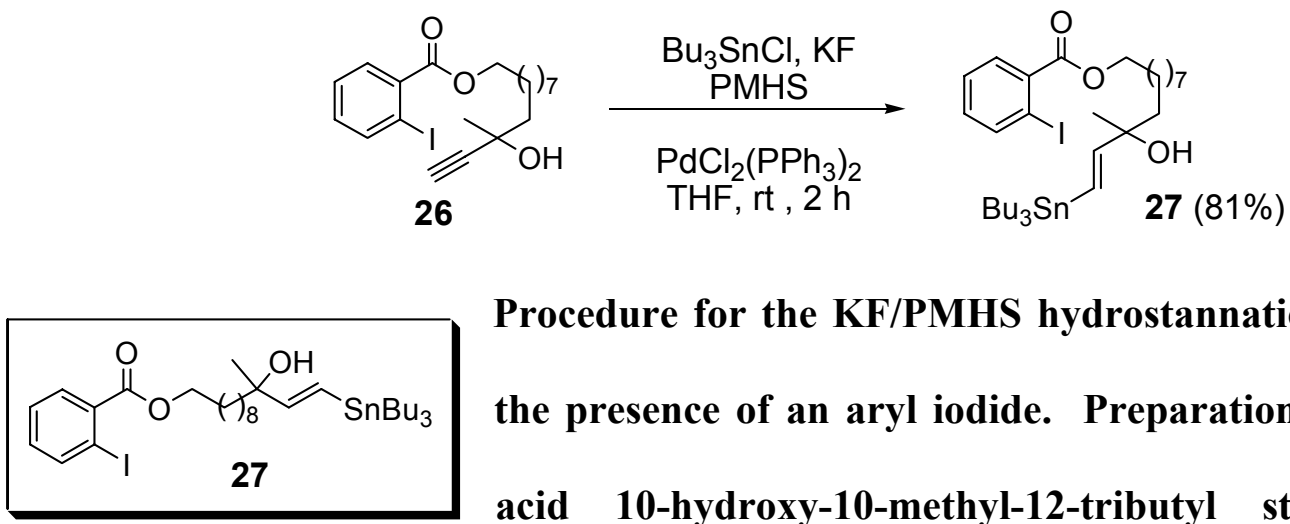

Procedure for the KF/PMHS hydrostannation of an alkyne in the presence of an aryl iodide. Preparation of 2-iodo-benzoic acid 10-hydroxy-10-methyl-12-tributyl stannanyl-dodec-11-

enyl ester (27) (Scheme 5). Applying the same conditions as for the trimethylvinylstannane (28), except that $\mathrm{Bu}_{3} \mathrm{SnCl}$ was used, produced, after column chromatography [silica gel; column chromatography [silica gel; 95:5 hexane/EtOAc, 1\% TEA] 2-iodo-benzoic acid 10-hydroxy-10methyl-12-tributylstannanyl-dodec-11-enyl ester (1.32 g, 65\%) as an oil. IR (neat) $3447 \mathrm{~cm}^{-1} ;{ }^{1} \mathrm{H}$ NMR (300 MHz, $\left.\mathrm{CDCl}_{3}\right) \delta 0.88(\mathrm{t}, J=7.2 \mathrm{~Hz}, 9 \mathrm{H}), 1.20-1.62(\mathrm{~m}, 36 \mathrm{H}), 1.77(\mathrm{~m}, 2 \mathrm{H}), 4.33(\mathrm{t}$, $J=6.7 \mathrm{~Hz}, 2 \mathrm{H}), 6.05(\mathrm{~m}, 2 \mathrm{H}), 7.13(\mathrm{td}, J=1.8,7.8 \mathrm{~Hz}, 1 \mathrm{H}), 7.39(\mathrm{td}, J=1.1,7.6 \mathrm{~Hz}, 1 \mathrm{H})$, $7.78(\mathrm{dd}, J=1.6,7.7 \mathrm{~Hz}, 1 \mathrm{H}), 7.98(\mathrm{dd}, J=1.1,8.0 \mathrm{~Hz}, 1 \mathrm{H}) ;{ }^{13} \mathrm{C} \mathrm{NMR}\left(75 \mathrm{MHz}, \mathrm{CDCl}_{3}\right) \delta 9.4$, $13.7,23.9,25.9,27.2,27.8,28.5,29.0,29.2,29.4,29.5,29.9,42.2,65.7,74.6,93.9,122.9,127.8$, 130.7, 132.4, 135.4, 141.1, 154.7, 166.5; HRMS (EI) $m / z$ 677.1502 [(M $\left.{ }^{+}\right)$calcd. for $\mathrm{C}_{32} \mathrm{H}_{55} \mathrm{IO}_{3} \mathrm{Sn}$ 677.1519]. 


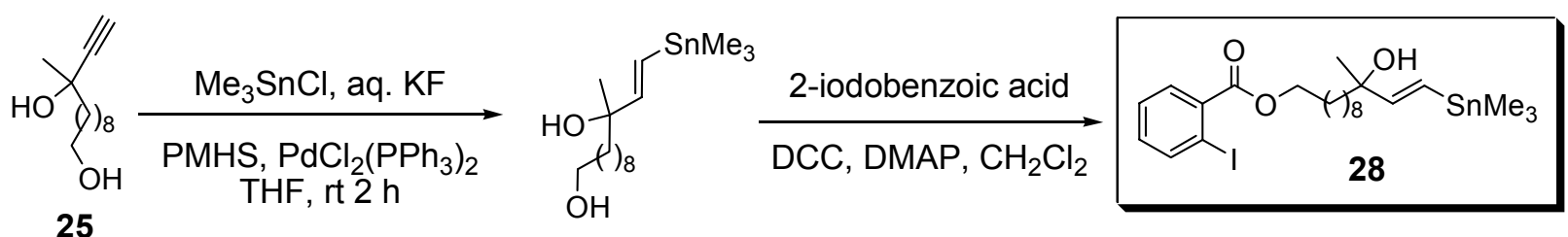

Procedure for the KF/PMHS hydrostannation of an alkyne. Preparation of 10-methyl-12trimethylstannanyl-dodec-11-ene-1,10-diol (Control Experiment). Apply the above conditions to 10-methyl-dodec-11-yne-1,10-diol (25) (2.06 g, $9.7 \mathrm{mmol})$ afforded after column chromatography [silica gel; 50:50 hexane/EtOAc, 1\% TEA] 10-methyl-12-trimethylstannanyldodec-11-ene-1,10-diol (3.13 g, 86\%) as a thick waxy oil.

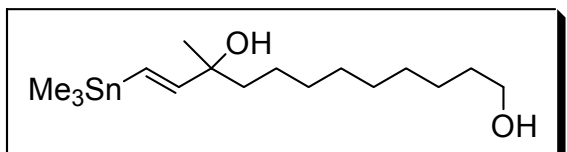

IR (neat) $3304 \mathrm{~cm}^{-1} ;{ }^{1} \mathrm{H}$ NMR $\left(300 \mathrm{MHz}, \mathrm{CDCl}_{3}\right) \delta 0.11(\mathrm{~s}, 9$ H), 1.20-1.40 (m, $17 \mathrm{H}), 1.43-1.61(\mathrm{~m}, 2 \mathrm{H}), 1.64(\mathrm{br} \mathrm{s}, 2 \mathrm{H})$,

$3.63(\mathrm{t}, J=6.5 \mathrm{~Hz}, 2 \mathrm{H}), 6.02(\mathrm{~d}, J=19.3 \mathrm{~Hz}, 1 \mathrm{H}), 6.15(\mathrm{~d}, J=19.3 \mathrm{~Hz}, 1 \mathrm{H}) ;{ }^{13} \mathrm{C}$ NMR $(75$ $\left.\mathrm{MHz}, \mathrm{CDCl}_{3}\right) \delta-9.5,23.8,25.7,27.5,29.3,29.4,29.5,30.0,32.7,42.2,63.0,74.4,124.1,154.2$ HRMS (EI) $m / z 363.1344\left[(\mathrm{M}-\mathrm{Me})^{+}\right.$calcd. for $\left.\mathrm{C}_{15} \mathrm{H}_{31} \mathrm{O}_{2} \mathrm{Sn} 363.1346\right]$.

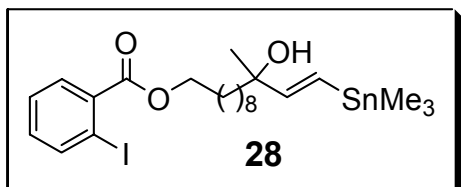

Procedure for a DCC mediated coupling. Preparation of 2iodo-benzoic acid 10-hydroxy-10-methyl-12trimethylstannanyl-dodec-11-enyl ester (Control Experiment).

2-Iodobenzoic acid (1.56 g, $6.31 \mathrm{mmol})$, 10-methyl-12-trimethylstannanyl-dodec-11-ene-1,10diol $(2.50 \mathrm{~g}, 6.63 \mathrm{mmol}), \mathrm{DCC}\left(6.63 \mathrm{~mL}\right.$ of a $1 \mathrm{M}$ solution in $\left.\mathrm{CH}_{2} \mathrm{Cl}_{2}, 6.63 \mathrm{mmol}\right)$, DMAP (154 $\mathrm{mg}, 1.26 \mathrm{mmol})$ were added to dry $\mathrm{CH}_{2} \mathrm{Cl}_{2}(65 \mathrm{~mL})$ at room temperature. The mixture was allowed to stir until complete by TLC $(5 \mathrm{~h})$. Once complete the reaction was filtered through a plug of celite and the filtrate was concentrated. The resulting residue was purified by column chromatography [silica gel; 90:10 hexane/EtOAc] to afford 2-iodo-benzoic acid 10-hydroxy-10- 
methyl-12-trimethylstannanyl-dodec-11-enyl ester (28) $(2.46 \mathrm{~g}, 64 \%)$ as an oil. For spectroscopic data see above.
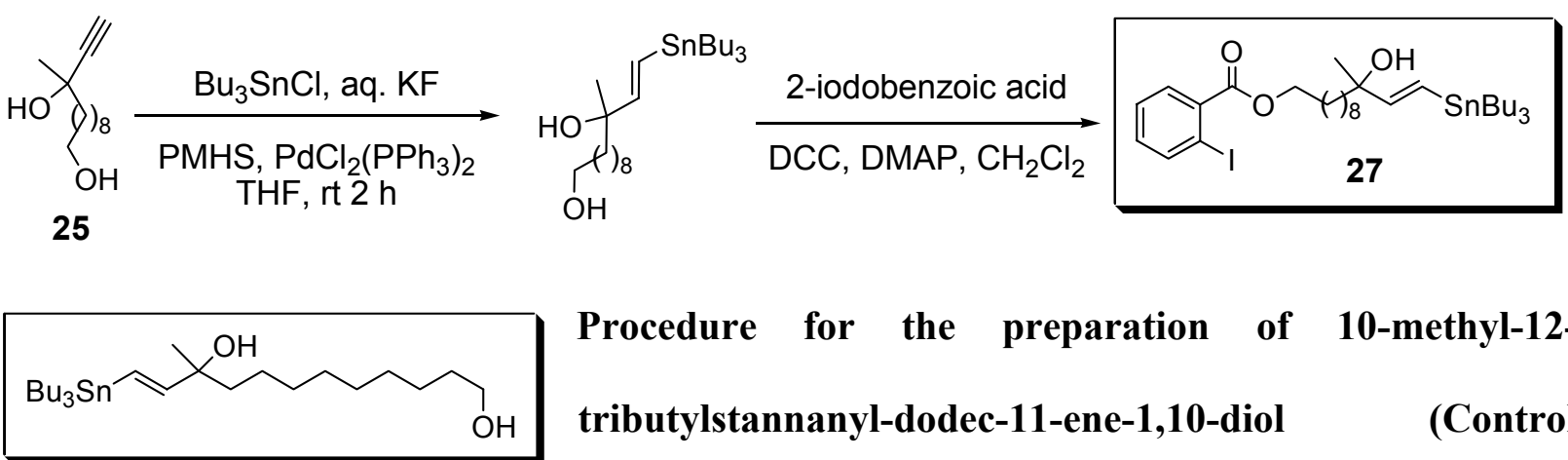

Procedure for the preparation of 10-methyl-12tributylstannanyl-dodec-11-ene-1,10-diol

(Control

experiment). $\mathrm{PdCl}_{2}\left(\mathrm{PPh}_{3}\right)_{2}(174 \mathrm{mg}, 0.19 \mathrm{mmol})$ was added to a flask containing THF (150 mL). 10-methyl-dodec-11-yne-1,10-diol (25) (4.0 g, $18.84 \mathrm{mmol}), \mathrm{Bu}_{3} \mathrm{SnCl}$ (6.10 mL, 22.61 $\mathrm{mmol}), \mathrm{KF}(3.28 \mathrm{~g}, 56.52 \mathrm{mmol}), \mathrm{H}_{2} \mathrm{O}(10 \mathrm{~mL})$ and PMHS (2.54 mL, $\left.28.26 \mathrm{mmol}\right)$ were added successively. This mixture was stirred at room temperature for $2 \mathrm{~h}$. The reaction was then diluted with Ether and washed with brine. The aqueous phase was extracted with Ether and the combined organics were dried $\left(\mathrm{MgSO}_{4}\right)$, filtered, and concentrated. The resulting residue was purified by column chromatography [silica gel; 75:25 hexane/EtOAc, 1\% TEA] to afford 10methyl-12-tributylstannanyl-dodec-11(E)-ene-1,10-diol (8.64 g, 91\%) as an oil. IR (neat) 3447 $\mathrm{cm}^{-1} ;{ }^{1} \mathrm{H}$ NMR $\left(500 \mathrm{MHz}, \mathrm{CDCl}_{3}\right) \delta$ 0.80-0.95 (m, $\left.15 \mathrm{H}\right), 1.20-1.40$ (m, $\left.23 \mathrm{H}\right), 1.43-1.60(\mathrm{~m}, 10$ H), $3.62(\mathrm{q}, J=6.7 \mathrm{~Hz}, 2 \mathrm{H}), 6.00(\mathrm{~d}, J=19.2 \mathrm{~Hz}, 1 \mathrm{H}), 6.06(\mathrm{~d}, J=19.2 \mathrm{~Hz}, 1 \mathrm{H}) ;{ }^{13} \mathrm{C}$ NMR $(75$ $\left.\mathrm{MHz}, \mathrm{CDCl}_{3}\right) \delta 9.5,13.7,23.9,25.7,27.2,27.8,29.1,29.4,29.5,30.0,32.8,42.3,63.0,74.6$, 123.0, 154.8; HRMS (EI) $m / z$ 504.2991 [( $\left.\mathrm{M}^{+}\right)$, calcd. for $\mathrm{C}_{25} \mathrm{H}_{52} \mathrm{O}_{2} \mathrm{Sn}$ 504.2989]. 


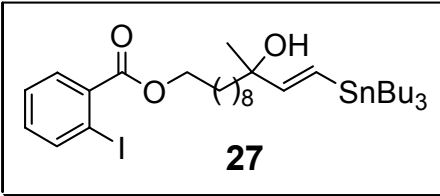

Procedure for the preparation of 2-iodo-benzoic acid 10hydroxy-10-methyl-12-tributylstannanyl-dodec-11-enyl ester (Control experiment). 2-Iodobenzoic acid (40) (714 mg, 2.88 mmol), 10-methyl-12-tributylstannanyl-dodec-11(E)-ene-1,10-diol (1.52 g, $3.02 \mathrm{mmol})$, DCC (3.02 $\mathrm{mL}$ of a 1M THF solution, $3.02 \mathrm{mmol}$ ) and DMAP (73 $\mathrm{mg}, 0.60 \mathrm{mmol}$ ) were dissolved in $\mathrm{CH}_{2} \mathrm{Cl}_{2}(33 \mathrm{~mL})$. This mixture was stirred at $25^{\circ} \mathrm{C}$ for $5 \mathrm{~h}$. Once the reaction was complete it was filtered through a plug of celite and the plug washed with $\mathrm{CH}_{2} \mathrm{Cl}_{2}$. The filtrate was concentrated and the resulting residue was purified by column chromatography [silica gel; 95:5 hexane/EtOAc, 1\% TEA] to afford 2-iodo-benzoic acid 10-hydroxy-10-methyl-12tributylstannanyl-dodec-11-enyl ester (27) $(1.32 \mathrm{~g}, 65 \%)$ as a clear oil. See above for spectroscopic data.

Survey of Catalyst/Ligand Combinations and Conditions (Scheme 5, a-h)

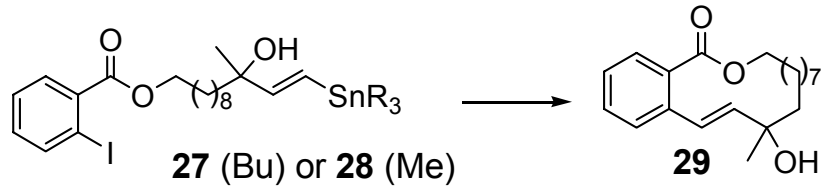

\begin{tabular}{cccccc}
\hline Entry & $\mathrm{R}$ & Catalyst & Solvent & Temp/time & Isolated Yield \\
\hline 1 & $\mathrm{Bu}$ & $\mathrm{Pd}_{2} \mathrm{dba}_{3} / \mathrm{AsPh}_{3}(1: 4)$ & $\operatorname{NMP}(0.005 \mathrm{M})$ & $60{ }^{\circ} \mathrm{C} / 22 \mathrm{~h}$ & $60 \%$ \\
2 & $\mathrm{Bu}$ & $\mathrm{Pd}_{2} \mathrm{dba}_{3} / \mathrm{AsPh}_{3}(1: 4)$ & $\operatorname{THF}(0.005 \mathrm{M})$ & $70{ }^{\circ} \mathrm{C} / 28 \mathrm{~h}$ & $52 \%$ \\
3 & $\mathrm{Bu}$ & $\mathrm{Pd}_{2} \mathrm{dba}_{3} / \mathrm{TFP}(1: 4)$ & $\operatorname{NMP}(0.005 \mathrm{M})$ & $60{ }^{\circ} \mathrm{C} / 24 \mathrm{~h}$ & $61 \%$ \\
4 & $\mathrm{Bu}$ & $\mathrm{Pd}_{2} \mathrm{dba}_{3} / \mathrm{TFP}(1: 4)$ & $\operatorname{THF}(0.005 \mathrm{M})$ & $70^{\circ} \mathrm{C} / 27 \mathrm{~h}$ & $63 \%$ \\
5 & $\mathrm{Me}$ & $\mathrm{Pd}_{2} \mathrm{dba}_{3} / \mathrm{AsPh}_{3}(1: 4)$ & $\operatorname{NMP}(0.005 \mathrm{M})$ & $60{ }^{\circ} \mathrm{C} / 14 \mathrm{~h}$ & $72 \%$ \\
6 & $\mathrm{Me}$ & $\mathrm{Pd}_{2} \mathrm{dba}_{3} / \mathrm{AsPh}_{3}(1: 4)$ & $\operatorname{THF}(0.005 \mathrm{M})$ & $70^{\circ} \mathrm{C} / 15 \mathrm{~h}$ & $63 \%$ \\
7 & $\mathrm{Me}$ & $\mathrm{Pd}_{2} \mathrm{dba}_{3} / \mathrm{TFP}(1: 4)$ & $\operatorname{NMP}(0.005 \mathrm{M})$ & $60^{\circ} \mathrm{C} / 10 \mathrm{~h}$ & $74 \%$ \\
8 & $\mathrm{Me}$ & $\mathrm{Pd}_{2} \mathrm{dba}_{3} / \mathrm{TFP}(1: 4)$ & $\operatorname{THF}(0.005 \mathrm{M})$ & $70^{\circ} \mathrm{C} / 12 \mathrm{~h}$ & $73 \%$ \\
\hline
\end{tabular}

General procedure for the intramolecular Stille coupling control. Preparation of 16-hydroxy-16-methyl-7,8,9,10,11,12,13,14,15,16- 
decahydro-6-oxa-benzocyclohexadecen-5-one (29) (entry 1). To $100 \mathrm{~mL}$ of degassed (Ar) NMP (0.005 M) was added $\mathrm{Pd}_{2} \mathrm{dba}_{3}(14 \mathrm{mg}, 0.015 \mathrm{mmol})$ and $\mathrm{AsPh}_{3}(19 \mathrm{mg}, 0.06 \mathrm{mmol})$. This mixture was stirred for $10 \mathrm{~min}$ while Ar was bubbled through the solution. 2-Iodo-benzoic acid 10-hydroxy-10-methyl-12-tributylstannanyl-dodec-11-enyl ester (27) (354 mg, $0.5 \mathrm{mmol}$ ) was added in one portion. The mixture was then heated at $\sim 60^{\circ} \mathrm{C}$ for $22 \mathrm{~h}$. The reaction was then cooled to room temperature and diluted with $\mathrm{Et}_{2} \mathrm{O}$. After washing with water and separation, the aqueous phase was extracted with $\mathrm{Et}_{2} \mathrm{O}(3 \mathrm{x})$. The combined organics were dried $\left(\mathrm{MgSO}_{4}\right)$, filtered, and concentrated. The resulting residue was purified by column chromatography [silica gel; 80:20 hexane/EtOAc] to afford 16-hydroxy-16-methyl-7,8,9,10,11,12,13,14,15,16decahydro-6-oxa-benzocyclohexadecen-5-one (29) (90 mg, $60 \%$ ) as an oil. IR (neat) $3487 \mathrm{~cm}^{-1}$; ${ }^{1} \mathrm{H}$ NMR $\left(300 \mathrm{MHz}, \mathrm{CDCl}_{3}\right) \delta 1.21-1.51(\mathrm{~m}, 15 \mathrm{H}), 1.65-1.91(\mathrm{~m}, 5 \mathrm{H}), 4.47(\mathrm{t}, J=4.9 \mathrm{~Hz}, 2 \mathrm{H})$, $6.12(\mathrm{~d}, J=16.2 \mathrm{~Hz}, 1 \mathrm{H}), 7.23-7.37(\mathrm{~m}, 2 \mathrm{H}), 7.45(\mathrm{t}, J=8.8 \mathrm{~Hz}, 1 \mathrm{H}), 7.56(\mathrm{~d}, J=7.7 \mathrm{~Hz}, 1 \mathrm{H})$, $7.78(\mathrm{~d}, J=8.9 \mathrm{~Hz}, 1 \mathrm{H}) ;{ }^{13} \mathrm{C} \mathrm{NMR}\left(75 \mathrm{MHz}, \mathrm{CDCl}_{3}\right) \delta 23.5,24.3,26.4,26.8,26.9,27.7,28.4$, $29.1,41.6,63.8,73.7,126.1,126.9,129.8,129.9,131.5,137.9,139.4,168.2 ;$ HRMS (EI) $m / z$ 316.2038 [(M+) calcd. for $\left.\mathrm{C}_{20} \mathrm{H}_{28} \mathrm{O}_{3} 316.2038\right]$.

Intramolecular Stille coupling control. Use of tributylstannane with $\mathrm{AsPh}_{3}$ and THF. Preparation of 16-hydroxy-16-methyl-7,8,9,10,11,12,13,14,15,16-decahydro-6-oxabenzocyclohexadecen-5-one (29) (entry 2). Applying the above conditions using 2-iodobenzoic acid 10-hydroxy-10-methyl-12-tributylstannanyl-dodec-11-enyl ester (27) (354 mg, 0.5 $\mathrm{mmol})$ and $\mathrm{AsPh}_{3}(19 \mathrm{mg}, .06 \mathrm{mmol})$ in $\mathrm{THF}(0.005 \mathrm{M})$ at $70{ }^{\circ} \mathrm{C}$ for $28 \mathrm{~h}$ after column chromatography [silica gel; 80:20 hexane/EtOAc] afforded 16-hydroxy-16-methyl7,8,9,10,11,12,13,14,15,16-decahydro-6-oxa-benzocyclohexadecen-5-one (29) (79 mg, 52\%) as an oil. For spectroscopic data see above. 
Intramolecular Stille coupling control. Use of tributylstannane with TFP and NMP. Preparation of 16-hydroxy-16-methyl-7,8,9,10,11,12,13,14,15,16-decahydro-6-oxabenzocyclohexadecen-5-one (29) (entry 3). Applying the above conditions using 2-iodobenzoic acid 10-hydroxy-10-methyl-12-tributylstannanyl-dodec-11-enyl ester (27) (354 mg, $0.48 \mathrm{mmol})$ and TFP $(14 \mathrm{mg}, 0.06 \mathrm{mmol})$ in NMP $(0.005 \mathrm{M})$ at $60{ }^{\circ} \mathrm{C}$ for $24 \mathrm{~h}$ after column chromatography [silica gel; 80:20 hexane/EtOAc] afforded 16-hydroxy-16-methyl7,8,9,10,11,12,13,14,15,16-decahydro-6-oxa-benzocyclohexadecen-5-one (29) (92 mg, $61 \%)$ as an oil. For spectroscopic data see above.

Intramolecular Stille coupling control. Use of tributylstannane with TFP and THF. Preparation of 16-hydroxy-16-methyl-7,8,9,10,11,12,13,14,15,16-decahydro-6-oxabenzocyclohexadecen-5-one (29) (entry 4). Applying the above conditions using 2-iodobenzoic acid 10-hydroxy-10-methyl-12-tributylstannanyl-dodec-11-enyl ester (27) (367 mg, $0.24 \mathrm{mmol})$ and TFP (14 mg, $0.06 \mathrm{mmol})$ in THF $(0.005 \mathrm{M})$ at $70{ }^{\circ} \mathrm{C}$ for $27 \mathrm{~h}$ after column chromatography [silica gel; 80:20 hexane/EtOAc] afforded 16-hydroxy-16-methyl7,8,9,10,11,12,13,14,15,16-decahydro-6-oxa-benzocyclohexadecen-5-one (29) (99 mg, 63 \%) as an oil. For spectroscopic data see above.

Intramolecular Stille coupling control. Use of trimethylstannane with $\mathrm{AsPh}_{3}$ and NMP. Preparation of 16-hydroxy-16-methyl-7,8,9,10,11,12,13,14,15,16-decahydro-6-oxabenzocyclohexadecen-5-one (29) (entry 5). Applying the above conditions using 2-iodobenzoic acid 10-hydroxy-10-methyl-12-trimethylstannanyl-dodec-11-enyl ester (28) (304 mg, $0.5 \mathrm{mmol})$ and $\mathrm{AsPh}_{3}(19 \mathrm{mg}, 0.06 \mathrm{mmol})$ in $\mathrm{NMP}(0.005 \mathrm{M})$ at $60{ }^{\circ} \mathrm{C}$ for $14 \mathrm{~h}$ after column chromatography [silica gel; 80:20 hexane/EtOAc] afforded 16-hydroxy-16-methyl- 
7,8,9,10,11,12,13,14,15,16-decahydro-6-oxa-benzocyclohexadecen-5-one (29) (114 mg, 72 \%) as an oil. For spectroscopic data see above.

Intramolecular Stille coupling control. Use of trimethylstannane with $\mathrm{AsPh}_{3}$ and THF. Preparation of 16-hydroxy-16-methyl-7,8,9,10,11,12,13,14,15,16-decahydro-6-oxabenzocyclohexadecen-5-one (29) (entry 6). Applying the above conditions using 2-iodobenzoic acid 10-hydroxy-10-methyl-12-trimethylstannanyl-dodec-11-enyl ester (28) (304 mg, $0.5 \mathrm{mmol})$ and $\mathrm{AsPh}_{3}(19 \mathrm{mg}, 0.06 \mathrm{mmol})$ in $\mathrm{THF}(0.005 \mathrm{M})$ at $70{ }^{\circ} \mathrm{C}$ for $15 \mathrm{~h}$ after column chromatography [silica gel; 80:20 hexane/EtOAc] afforded 16-hydroxy-16-methyl7,8,9,10,11,12,13,14,15,16-decahydro-6-oxa-benzocyclohexadecen-5-one (29) (100 mg, 63 \%) as an oil. For spectroscopic data see above.

Intramolecular Stille coupling control. Use of trimethylstannane with TFP and NMP. Preparation of 16-hydroxy-16-methyl-7,8,9,10,11,12,13,14,15,16-decahydro-6-oxabenzocyclohexadecen-5-one (44) (entry 7). Applying the above conditions using 2-iodobenzoic acid 10-hydroxy-10-methyl-12-trimethylstannanyl-dodec-11-enyl ester (28) (304 mg, $0.5 \mathrm{mmol})$ and TFP $(14 \mathrm{mg}, 0.06 \mathrm{mmol})$ in NMP $(0.005 \mathrm{M})$ at $60{ }^{\circ} \mathrm{C}$ for $10 \mathrm{~h}$ after column chromatography [silica gel; 80:20 hexane/EtOAc] afforded 16-hydroxy-16-methyl7,8,9,10,11,12,13,14,15,16-decahydro-6-oxa-benzocyclohexadecen-5-one (29) (117 mg, 74 \%) as an oil. For spectroscopic data see above.

Intramolecular Stille coupling control. Use of trimethylstannane with TFP and THF. Preparation of 16-hydroxy-16-methyl-7,8,9,10,11,12,13,14,15,16-decahydro-6-oxabenzocyclohexadecen-5-one (44) (entry 8). Applying the above conditions using 2-iodobenzoic acid 10-hydroxy-10-methyl-12-trimethylstannanyl-dodec-11-enyl ester (28) (304 mg, $0.5 \mathrm{mmol})$ and TFP $(14 \mathrm{mg}, 0.06 \mathrm{mmol})$ in THF $(0.005 \mathrm{M})$ at $70{ }^{\circ} \mathrm{C}$ for $12 \mathrm{~h}$ after column 
chromatography [silica gel; 80:20 hexane/EtOAc] afforded 16-hydroxy-16-methyl7,8,9,10,11,12,13,14,15,16-decahydro-6-oxa-benzocyclohexadecen-5-one (29) (115 mg, 73 \%) as an oil. For spectroscopic data see above.

Representative procedure for a one-pot hydrostannation/intra-molecular Stille. Use of the "Sn-F" route with everything added at once under high dilution. Preparation of 16hydroxy-16-methyl-7,8,9,10,11,12,13,14,15,16-decahydro-6-oxa-benzocyclo-hexadecen-5one (29) (Scheme 5, entry i). $\operatorname{Pd}_{2} \mathrm{dba}_{3}(27 \mathrm{mg}, 0.03 \mathrm{mmol})$ and TFP $(28 \mathrm{mg}, .12 \mathrm{mmol})$ were added to degassed THF $(200 \mathrm{~mL})$. At this time $\mathrm{Me}_{3} \mathrm{SnCl}(0.05 \mathrm{~mL}$ of a $1 \mathrm{M}$ solution in THF, $0.05 \mathrm{mmol})$, KF (87 mg, $1.5 \mathrm{mmol})$, water $(1 \mathrm{~mL})$, PMHS (0.09 mL, $1.5 \mathrm{mmol})$ and 2-iodobenzoic acid 10-hydroxy-10-methyl-dodec-11-ynyl ester (26) $(431 \mathrm{mg}, 1.0 \mathrm{mmol})$ were all added. This mixture was stirred for $14 \mathrm{~h}$ at $70{ }^{\circ} \mathrm{C}$. The reaction was then diluted with $\mathrm{Et}_{2} \mathrm{O}$ and washed with water. After separation of the phases, the aqueous phase was extracted with $\mathrm{Et}_{2} \mathrm{O}$. The combined organics were dried $\left(\mathrm{MgSO}_{4}\right)$, filtered, and concentrated. The resulting residue was purified by column chromatography [silica gel; 80:20 hexane/EtOAc] to afford 16-hydroxy16-methyl-7,8,9,10,11,12,13, 14,15,16-decahydro-6-oxa-benzocyclohexadecen-5-one (29) (70 $\mathrm{mg}, 23 \%)$ as an oil. For spectroscopic data see above.

Representative procedure for a one-pot hydrostannation/intra-molecular Stille. Use of syringe pump addition. Preparation of 16-hydroxy-16-methyl-7,8,9,10,11,12,13,14,15,16decahydro-6-oxa-benzocyclohexadecen -5-one (29) (Scheme 5, entry j). Applying the conditions noted above except that 2-iodo-benzoic acid 10-hydroxy-10-methyl-dodec-11-ynyl ester (26) (431 mg, $1.0 \mathrm{mmol})$ was added via syringe pump over $8 \mathrm{~h}$ at $70{ }^{\circ} \mathrm{C}$. After column chromatography [silica gel; 80:20 hexane/EtOAc] 16-hydroxy-16-methyl- 
7,8,9,10,11,12,13,14,15,16-decahydro-6-oxa-benzocyclohexadecen-5-one (29) (93 mg, 29\%) was obtained as an oil. For spectroscopic data see above.

Representative procedure for a one-pot hydrostannation/intra-molecular Stille. Use of the "Sn-F" route in conjunction with the "Sn-O" route with everything added at once under high dilution. Preparation of 16-hydroxy-16-methyl-7,8,9,10,11,12,13,14,15,16-decahydro6-oxa-benzocyclohexadecen-5-one (29) (Scheme 5, entry k). $\mathrm{Pd}_{2} \mathrm{dba}_{3}(27 \mathrm{mg}, 0.03 \mathrm{mmol}$ ) and TFP (28 mg, .12 mmol) were added to degassed THF (200 mL). At this time $\mathrm{Me}_{3} \mathrm{SnF}(9.1 \mathrm{mg}$, $0.05 \mathrm{mmol}), \mathrm{Na}_{2} \mathrm{CO}_{3}(159 \mathrm{mg}, 1.5 \mathrm{mmol})$, water $(1 \mathrm{~mL})$, PMHS $(0.09 \mathrm{~mL}, 1.5 \mathrm{mmol})$ and 2iodo-benzoic acid 10-hydroxy-10-methyl-dodec-11-ynyl ester (26) (431 mg, $1.0 \mathrm{mmol})$ were all added. This mixture was stirred for $12 \mathrm{~h}$ at $70{ }^{\circ} \mathrm{C}$. The reaction was then diluted with $\mathrm{Et}_{2} \mathrm{O}$ and washed with water. After separation of the phases, the aqueous phase was extracted with $\mathrm{Et}_{2} \mathrm{O}$. The combined organics were dried $\left(\mathrm{MgSO}_{4}\right)$, filtered, and concentrated. The resulting residue was purified by column chromatography [silica gel; 80:20 Hexane/EtOAc] to afford 16-hydroxy16-methyl-7,8,9,10,11,12,13,14,15,16-decahydro-6-oxa-benzocyclohexadecen-5-one (29) (130 $\mathrm{mg}, 41 \%)$ as an oil. For spectroscopic data see above.

Representative procedure for a one-pot hydrostannation/intramolecular Stille. Use of the "Sn-F" route in conjunction with the "Sn-O" route with syringe pump addition. Preparation of 16-hydroxy-16-methyl-7,8,9,10,11,12,13,14,15,16-decahydro-6-oxa-benzocyclohexa decen-5-one (29) (Scheme 5, entry l). Applying the conditions noted above except that 2-iodo-benzoic acid 10-hydroxy-10-methyl-dodec-11-ynyl ester (26) (431 mg, $1.0 \mathrm{mmol})$ was added via syringe pump over $8 \mathrm{~h}$ at $70{ }^{\circ} \mathrm{C}$. After column chromatography [silica gel; 80:20 hexane/EtOAc] 16-hydroxy-16-methyl-7,8,9,10,11,12,13,14,15,16-decahydro-6-oxa-benzocyclohexadecen-5-one (44) (150 mg, 47\%) was obtained as an oil. For spectroscopic data see above. 


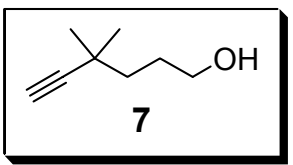

\section{Representative Procedure for the preparation of 4,4-dimethyl-hex-5-yn-}

1-ol (7) (Table 2, entry 1). Isopropyl acetylene (33) (7.51 mL, $73.4 \mathrm{mmol})$

was added to $50 \mathrm{~mL}$ of dry $\mathrm{Et}_{2} \mathrm{O}$ in a flame dried $500 \mathrm{~mL}$ round bottom flask under $\mathrm{N}_{2}$ and the solution was cooled to $0{ }^{\circ} \mathrm{C} . n$-BuLi $(92 \mathrm{~mL}$ of $1.6 \mathrm{M}$ solution in hexanes, $147 \mathrm{mmol})$ was then added dropwise via an addition funnel. When the addition was complete the solution had a clear yellow appearance. Upon addition of $N, N, N^{\prime}, N^{\prime}$-tetramethylethylenediamine $(11.65 \mathrm{~mL}, 77.1$ mmol) in one portion, the solution turned to a thick white slurry within minutes. This solution was then placed in a $60{ }^{\circ} \mathrm{C}$ oil bath and gently refluxed for 15 hours to produce a deep red solution (the dianion). The dianion solution was then allowed to cool to room temperature and then cooled to $-78^{\circ} \mathrm{C}$. Oxetane $(4.75 \mathrm{~mL}, 73.4 \mathrm{mmol})$ was then added followed by addition of $\mathrm{BF}_{3} \cdot \mathrm{OEt}_{2}(9.31 \mathrm{~mL}, 73.4 \mathrm{mmol})$ via a syringe pump over 6 hours. The solution was then warmed to room temperature and diluted with $1 \mathrm{M} \mathrm{HCl}$ and stirred for 30 minutes. The mixture was then diluted with $\mathrm{Et}_{2} \mathrm{O}$ and the phases separated. The aqueous phase was extracted with $\mathrm{Et}_{2} \mathrm{O}(3 \mathrm{x})$ and the combined organics were washed with brine, dried over $\mathrm{MgSO}_{4}$, filtered and concentrated. The resulting residue was purified by column chromatography [silica gel; 90:10 to 80:20 hexane/EtOAc] to afford 4,4-dimethyl-hex-5-yn-1-ol ${ }^{15}$ (7) $(2.58 \mathrm{~g}, 35 \%)$ as a pale yellow oil. ${ }^{1} \mathrm{H}$ NMR (300 MHz, $\left.\mathrm{CDCl}_{3}\right) \oint 1.24$ (s, $\left.6 \mathrm{H}\right), 1.43-1.53$ (m, $\left.2 \mathrm{H}\right), 1.69-1.83$ (m, $\left.3 \mathrm{H}\right), 2.11$ (s, $1 \mathrm{H}), 3.70(\mathrm{t}, J=6.46 \mathrm{~Hz}, 2 \mathrm{H}) ;{ }^{13} \mathrm{C}\left(75 \mathrm{MHz}, \mathrm{CDCl}_{3}\right) \delta .28 .7,29.1,30.7,39.3,63.2,67.9,91.6$.

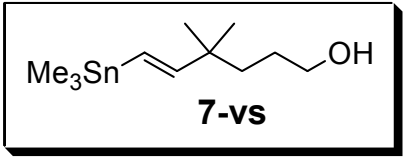

Procedure for the palladium catalyzed hydrostannation of 4,4dimethyl-hex-5-yn-1-ol Preparation of 4,4-dimethyl-6trimethylstannanyl-hex-5-en-1-ol (7-vs) (Control Experiment). To $50 \mathrm{~mL}$ of THF was added $\mathrm{PdCl}_{2}\left(\mathrm{PPh}_{3}\right)_{2}(0.029 \mathrm{~g}, 0.041 \mathrm{mmol})$, 4,4-dimethyl-hex-5-yn-1-ol (7) (0.5213 g, $\left.4.13 \mathrm{mmol}\right)$, $\mathrm{Me}_{3} \mathrm{SnCl}(5 \mathrm{~mL}$ of a $1 \mathrm{M}$ solution in THF, $4.96 \mathrm{mmol}), \mathrm{KF}\left(.7199 \mathrm{~g}, 12.4 \mathrm{mmol} ; 3 \mathrm{~mL} \mathrm{H} \mathrm{H}_{2} \mathrm{O}\right)$, 
PMHS $(0.37 \mathrm{~mL}, 6.2 \mathrm{mmol})$ and TBAF ( 1 drop of a $1 \mathrm{M}$ solution in THF, ca. $0.8 \mathrm{~mol} \%)$. This mixture was then stirred for 1 hour. The reaction was then separated and the aqueous phase extracted with $\mathrm{Et}_{2} \mathrm{O}(2 \mathrm{x})$. The combined organics were then washed with brine, dried over $\mathrm{MgSO}_{4}$, filtered, and concentrated. The resulting residue was purified by column chromatography [silica gel; 90:10 hexane/EtOAc, $1 \% \mathrm{NEt}_{3}$ ] to afford 4,4-dimethyl-6trimethylstannanyl-hex-5-en-1-ol (7-vs) (1.05 g, 88\%) as a light yellow oil. IR (neat) $3327 \mathrm{~cm}^{-1}$; ${ }^{1} \mathrm{H}$ NMR (300 MHz, $\left.\mathrm{CDCl}_{3}\right) \delta 0.11(\mathrm{~m}, 9 \mathrm{H}), 0.99(\mathrm{~s}, 6 \mathrm{H}), 1.28-1.36(\mathrm{~m}, 2 \mathrm{H}), 1.42-1.56(\mathrm{~m}, 3$ $\mathrm{H}), 3.61(\mathrm{~m}, 2 \mathrm{H}), 5.87(\mathrm{~m}, 2 \mathrm{H}) ;{ }^{13} \mathrm{C}\left(75 \mathrm{MHz}, \mathrm{CDCl}_{3}\right) \delta-9.6,26.6,28.0,38.3,38.5,63.7,122.9$, 157.7; HRMS (EI) m/z $277.0613\left[\left(\mathrm{M}^{+}-\mathrm{CH}_{3}\right)\right.$ calcd. for $\left.\mathrm{C}_{10} \mathrm{H}_{21} \mathrm{OSn} 277.0616\right]$.
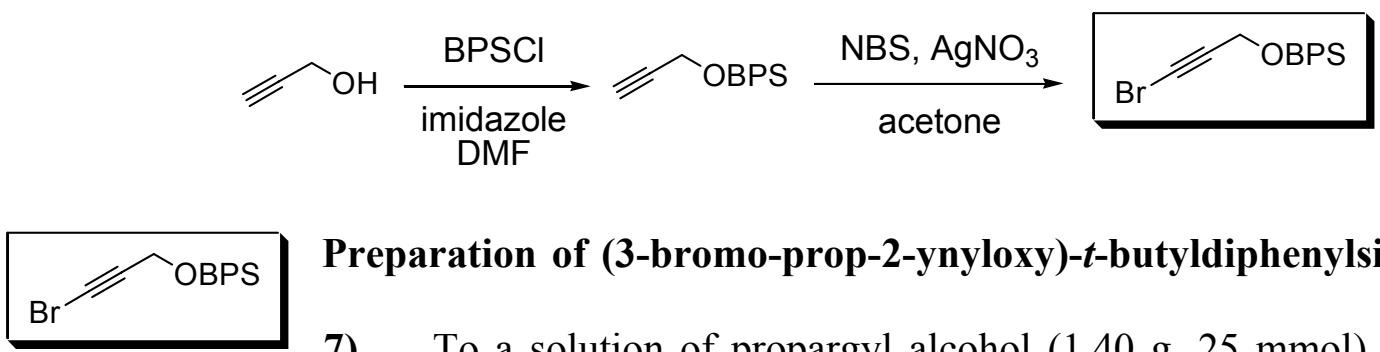

\section{Preparation of (3-bromo-prop-2-ynyloxy)-t-butyldiphenylsilane (Scheme}

7). To a solution of propargyl alcohol (1.40 g, $25 \mathrm{mmol})$ and imidazole (3.74 g, $55 \mathrm{mmol})$ in DMF (25 mL) was added BPSCl (7.15 mL, $27.5 \mathrm{mmol})$ dropwise at room temperature and stirred for $5 \mathrm{~h}$. The reaction was then partitioned between sat. aq. $\mathrm{NH}_{4} \mathrm{Cl}(100$ $\mathrm{mL})$ and hexane $(100 \mathrm{~mL})$ and the aqueous phase extracted with hexane $(2 \mathrm{x})$. The combined organics were washed with brine, dried over $\mathrm{MgSO}_{4}$, filtered, and concentrated. The resulting residue was purified by column chromatography [silica gel; 95:5 hexane/EtOAc] to afford $t$ butyl-diphenyl-prop-2-ynyloxy-silane (7.36 g, 100\%). The silylated propargyl alcohol was then dissolved in $75 \mathrm{~mL}$ of dry acetone. $N$-Bromosuccinimide (4.90 g, $27.5 \mathrm{mmol})$ and $\mathrm{AgNO}_{3}(375$ $\mathrm{mg}, 2.2 \mathrm{mmol}$ ) were added and the reaction was allowed to stir for 8 hours. The reaction was then diluted with ether and washed with $\mathrm{H}_{2} \mathrm{O}$. The aqueous phase was extracted with ether. The combined organics were washed with brine, dried over $\mathrm{MgSO}_{4}$, filtered, and concentrated. The 
resulting residue was then purified by column chromatography [silica, 95:5 hexane/EtOAc] to afford (3-bromo-prop-2-ynyloxy)-t-butyldiphenylsilane (7.93 g, 85\%) as a yellow oil. IR (neat) 3071, $2221 \mathrm{~cm}^{-1}$; ${ }^{1} \mathrm{H}$ NMR $\left(300 \mathrm{MHz}, \mathrm{CDCl}_{3}\right) \delta 1.11(\mathrm{~s}, 9 \mathrm{H}), 4.38(\mathrm{~s}, 2 \mathrm{H}), 7.40-7.50(\mathrm{~m}, 6 \mathrm{H})$,

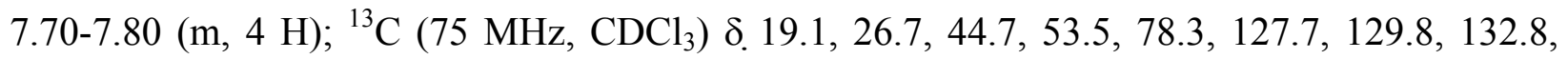
135.6; HRMS (EI) $\mathrm{m} / \mathrm{z} 314.9851$ [(M-t-Bu) ${ }^{+}$calcd for $\left.\mathrm{C}_{15} \mathrm{H}_{12} \mathrm{BrOSi} 314.9841\right]$.

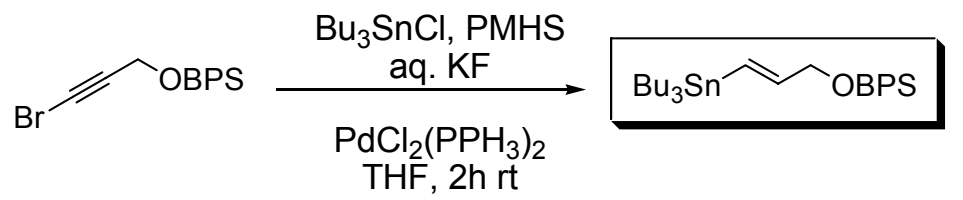

$\mathrm{Bu}_{3} \mathrm{Sn}_{\mathrm{OBPS}}$ Preparation of $\boldsymbol{t}$-butyl-diphenyl-(3-tributylstannanyl-allyloxy)-silane (Scheme 7). To $100 \mathrm{~mL}$ of THF was added (3-bromo-prop-2-ynyloxy)-t-butyl-diphenyl-silane (7.55 g, $20.2 \mathrm{mmol}), \mathrm{Bu}_{3} \mathrm{SnCl}(6.60 \mathrm{ml}, 24.3 \mathrm{mmol}), \mathrm{KF}$ (3.55 g, $\left.61 \mathrm{mmol}\right), \mathrm{H}_{2} \mathrm{O}(6 \mathrm{~mL})$, PMHS (1.82 mL, $30.3 \mathrm{mmol}$ ), TBAF (1 drop of a $1 \mathrm{M}$ solution in THF, ca. $0.8 \mathrm{~mol} \%$ ), and $\mathrm{PdCl}_{2}\left(\mathrm{PPh}_{3}\right)_{2}$. The reaction was stirred at room temperature until complete by TLC ( 2 hours). Once complete, the reaction was diluted with ether. The phases were separated and the aqueous phase extracted with ether. The combined organics were washed with brine, dried over $\mathrm{MgSO}_{4}$, filtered, and concentrated. The resulting residue was purified by column chromatography [silica gel, hexane, $\left.1 \% \mathrm{NEt}_{3}\right]$ to afford $(E)$-t-butyl-diphenyl-(3-tributylstannanyl-allyloxy)-silane (8.27 g, 70\%) as a clear oil. IR (neat) 2956, $1112 \mathrm{~cm}^{-1} ;{ }^{1} \mathrm{H}$ NMR (500 MHz, $\left.\mathrm{CDCl}_{3}\right) \delta 0.94(\mathrm{~m}, 15 \mathrm{H})$, $1.12(\mathrm{~s}, 9 \mathrm{H}), 1.37$ (m, $6 \mathrm{H}), 1.56(\mathrm{~m}, 6 \mathrm{H}), 4.30(\mathrm{dd}, J=1.8,4.2 \mathrm{~Hz}, 2 \mathrm{H}), 6.02-6.43(\mathrm{~m}, 2 \mathrm{H})$, 7.38-7.48 (m, $6 \mathrm{H})$, 7.71-7.77 (m, $4 \mathrm{H}) ;{ }^{13} \mathrm{C}\left(125 \mathrm{MHz}, \mathrm{CDCl}_{3}\right)$ 8 9.4, 13.7, 19.3, 26.9, 27.2, 29.1, 67.2, 126.9, 127.5, 129.5, 133.9, 135.6, 146.7; HRMS (EI) m/z 529.1950 [(M-Bu) ${ }^{+}$calcd. for $\mathrm{C}_{27} \mathrm{H}_{41} \mathrm{OSiSn}$ 529.1953]. 
$\mathrm{Br} \curvearrowright$ OBPS

32

\section{Preparation of (3-bromo-allyloxy)-t-butyl-diphenyl-silane (32) (Scheme}

7). $\mathrm{N}$-Bromosuccinimide $(3.07 \mathrm{~g}, 17.23 \mathrm{mmol})$ was added to a cold solution

of (E)-t-butyl-diphenyl-(3-tributylstannanyl-allyloxy)-silane $(9.61 \mathrm{~g}, 16.41 \mathrm{mmol})$ in $\operatorname{dry~} \mathrm{CH}_{2} \mathrm{Cl}_{2}$ $(100 \mathrm{~mL})$. Upon completion (TLC, $1 \mathrm{hr})$, the reaction was quenched by the addition of sat. aq. $\mathrm{Na}_{2} \mathrm{~S}_{2} \mathrm{O}_{3}(25 \mathrm{~mL}) . \mathrm{CH}_{2} \mathrm{Cl}_{2}$ was added and the aqueous phase extracted with $\mathrm{CH}_{2} \mathrm{Cl}_{2}(3 \mathrm{X})$. The combined organics were washed with brine, dried over $\mathrm{Na}_{2} \mathrm{SO}_{4}$, filtered, and concentrated. The resulting residue was purified by column chromatography [silica gel; hexanes] to afford $(E)-(3-$ bromo-allyloxy)-t-butyl-diphenyl-silane (32) (6.01 g, 97\%) as a clear liquid. IR 2959, 2857 , $1112 \mathrm{~cm}^{-1} ;{ }^{1} \mathrm{H}$ NMR $\left(300 \mathrm{MHz}, \mathrm{CDCl}_{3}\right) \delta 1.10(\mathrm{~s}, 9 \mathrm{H}), 4.17(\mathrm{~m}, 2 \mathrm{H}), 6.30(\mathrm{~m}, 1 \mathrm{H}), 6.38(\mathrm{~m}, 1$ $\mathrm{H}), 7.44(\mathrm{~m}, 6 \mathrm{H}), 7.70(\mathrm{~m}, 4 \mathrm{H}) ;{ }^{13} \mathrm{C}\left(75 \mathrm{MHz}, \mathrm{CDCl}_{3}\right) \delta 19.2,26.8,64.0,105.9,127.8,129.8$, 133.1, 135.5, 136.3; HRMS (EI) m/z 316.9998 [(M-Bu) ${ }^{+}$calcd. for $\left.\mathrm{C}_{15} \mathrm{H}_{14} \mathrm{BrOSi} 316.9997\right]$.

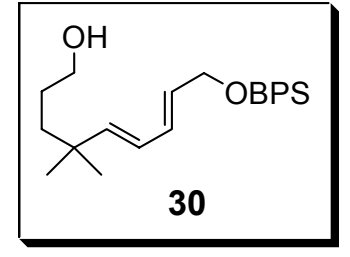

Preparation of 9-(t-butyldiphenylsilanyloxy)-4,4-dimethyl-nona-5,7dien-1-ol (30) (Scheme 7). Applying the above "Sn-F" one-pot catalytic Stille conditions to 4,4-dimethyl-hex-5-yn-1-ol (7) (126.2 mg, $1 \mathrm{mmol})$ and (E)-(3-bromo-allyloxy)-t-butyl-diphenyl-silane (32) $(563.1 \mathrm{mg}, 1.5 \mathrm{mmol})$ afforded after column chromatography [silica gel; 80:20 hexane/EtOAc] 9-(t-butyl-diphenyl-silanyloxy)-4,4dimethyl-nona-5,7-dien-1-ol (30) (336 mg, 80\%) as an oil. IR (neat) 3352, $3071 \mathrm{~cm}^{-1} ;{ }^{1} \mathrm{H}$ NMR $\left(500 \mathrm{MHz}, \mathrm{CDCl}_{3}\right) \delta 1.04(\mathrm{~s}, 6 \mathrm{H}), 1.08(\mathrm{~s}, 9 \mathrm{H}), 1.37(\mathrm{~m}, 3 \mathrm{H}), 1.51(\mathrm{~m}, 2 \mathrm{H}), 3.61(\mathrm{t}, J=6.4$ $\mathrm{Hz}, 2 \mathrm{H}), 4.25(\mathrm{dd}, J=1.1,5.1 \mathrm{~Hz}, 2 \mathrm{H}), 5.61(\mathrm{~d}, J=15.5 \mathrm{~Hz}, 1 \mathrm{H}), 5.70(\mathrm{dt}, J=5.1,15.2 \mathrm{~Hz}, 1$ H), $5.98(\mathrm{dd}, J=10.4,15.5 \mathrm{~Hz}, 1 \mathrm{H}), 6.24(\mathrm{dd}, J=10.4,15.2,1 \mathrm{H}), 7.36-7.45$ (m, $6 \mathrm{H}), 7.68-$ $7.72(\mathrm{~m}, 4 \mathrm{H}) ;{ }^{13} \mathrm{C}\left(125 \mathrm{MHz}, \mathrm{CDCl}_{3}\right) \delta 19.2,26.8,27.1,28.0,35.7,38.9,63.5,64.2,126.0$, 127.6, 129.5, 129.9, 130.5, 133.7, 135.5, 143.7; HRMS (EI) m/z $365.1923\left[(\mathrm{M}-\mathrm{Bu}-t)^{+}\right.$calcd. for $\left.\mathrm{C}_{23} \mathrm{H}_{29} \mathrm{O}_{2} \mathrm{Si} 365.1937\right]$. 


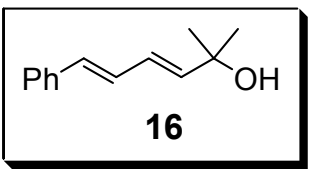

Representative procedure for the use of $\mathrm{Me}_{3} \mathrm{SnF}$ as the tin source. Preparation of 2-methyl-6-phenyl-hexa-3,5-dien-2-ol (16) (Control

Experiment). Tri-2-furylphosphine $(9.3 \mathrm{mg}, 0.04 \mathrm{mmol})$ was added to a solution of $\mathrm{Pd}_{2} \mathrm{bda}_{3}$ $(9.2 \mathrm{mg}, 0.01 \mathrm{mmol})$ in $\mathrm{Et}_{2} \mathrm{O}(5 \mathrm{~mL})$. After stirring at room temperature for $15 \mathrm{~min},(E)-\beta-$ bromostyrene (274.5 mg, $1.5 \mathrm{mmol}), \mathrm{Me}_{3} \mathrm{SnF}(11 \mathrm{mg}, 0.06 \mathrm{mmol})$, aq. KF (0.1743 g, $3 \mathrm{mmol}$; 1 $\mathrm{mL} \mathrm{H}_{2} \mathrm{O}$ ), TBAF (1 drop of a $1 \mathrm{M}$ solution in THF, ca. $0.8 \mathrm{~mol} \%$ ) and $\mathrm{PdCl}_{2}\left(\mathrm{PPh}_{3}\right)_{2}(7.0 \mathrm{mg}$, $0.01 \mathrm{mmol}$ ) were all added to the solution. The solution was heated to reflux and then a solution of 2-methyl-but-3-yn-2-ol (1) $(0.10 \mathrm{~mL}, 1 \mathrm{mmol})$ and PMHS $(0.09 \mathrm{~mL}, 1.5 \mathrm{mmol})$ in $\mathrm{Et}_{2} \mathrm{O}$ $(4 \mathrm{~mL})$ was added via a syringe pump over $11 \mathrm{hrs}$. The phases were separated and the organics washed with brine, dried over $\mathrm{MgSO}_{4}$, filtered, and concentrated. The resulting residue was purified by column chromatography [silica gel, 90:10 hexane/EtOAc] to afford 2-methyl-6phenyl-hexa-3,5-dien-2-ol (16) (152 $\mathrm{mg}, 81 \%)$ as an oil. For spectroscopic data see above.

Preparation of $\mathrm{Me}_{3} \mathrm{SnH}$. A solution of $\mathrm{Me}_{3} \mathrm{SnCl}(36.87 \mathrm{~mL}$ of a $1 \mathrm{M}$ solution in THF, 36.87 $\mathrm{mmol}), \mathrm{KF}(4.71 \mathrm{~g}, 81.11 \mathrm{mmol}), \mathrm{H}_{2} \mathrm{O}(5-10 \mathrm{~mL})$ and PMHS $(2.43 \mathrm{~mL}, 40.56 \mathrm{mmol})$ were added to a flask containing THF $(50 \mathrm{~mL})$. This mixture was then allowed to stir at room temperature until the initially formed $\mathrm{Me}_{3} \mathrm{SnF}$ precipitate disappeared. After 4-5 hours the reaction was complete, and the layers were separated. $\mathrm{Me}_{3} \mathrm{SnH}$ was distilled as a $2.74 \mathrm{M}$ solution in THF.

Representative procedure for the use of $6 \mathrm{~mol} \% \mathrm{Me}_{3} \mathrm{SnH}$ as the tin source. Preparation of 2-methyl-6-phenyl-hexa-3,5-dien-2-ol (16) (Control Experiment). Following the above procedure outlined for Table $1, \mathrm{Me}_{3} \mathrm{SnH}(0.11 \mathrm{~mL}$ of a $2.74 \mathrm{M}$ solution in THF, $0.30 \mathrm{mmol}),(E)-$ $\beta$-bromostyrene (1.37 g, $7.5 \mathrm{mmol})$ and 2-methyl-but-3-yn-2-ol (1) $(0.50 \mathrm{~mL}, 5 \mathrm{mmol})$ after column chromatography [silica gel, 90:10 hexane/EtOAc] 2-methyl-6-phenyl-hexa-3,5-dien-2-ol (16) (846 mg, 90\%) was afforded as an oil. For spectroscopic data see above. 


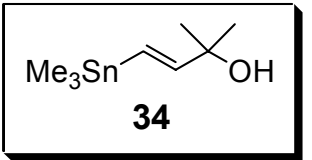

Preparation of $E$ )-2-methyl-4-(trimethylstannyl)but-3-en-2-ol (34). A flask containing THF $(50 \mathrm{~mL})$ was charged with $\mathrm{Me}_{3} \mathrm{SnCl}(18 \mathrm{~mL}, 18$ mmol; 1M solution in THF), 2-methyl-3-butyn-2-ol (1) $(2.43 \mathrm{~mL}, 15 \mathrm{mmol}), \mathrm{KF}$ (36 mmol), water $(5 \mathrm{~mL})$ and $\mathrm{PdCl}_{2}\left(\mathrm{PPh}_{3}\right)_{2}(126 \mathrm{mg}, 0.18 \mathrm{mmol})$ and TBAF (1 drop of a $1 \mathrm{M}$ solution in THF, ca. $0.8 \mathrm{~mol} \%$ ). After stirring at $25{ }^{\circ} \mathrm{C}$ for $2 \mathrm{~h}$, column chromatography [silica; 70:30 hexane/Ether, 1\% TEA] afforded (E)-2-methyl-4-(trimethylstannyl)-3-buten-2-ol (34) (3.17 g, 85\%) as a yellow oil. IR (neat): $3362 \mathrm{~cm}^{-1} ;{ }^{1} \mathrm{H}$ NMR $\left(300 \mathrm{MHz}, \mathrm{CDCl}_{3}\right) \oint 0.10(\mathrm{~s}, 9 \mathrm{H}), 1.27$ (s, $6 \mathrm{H}), 1.64$ (br s, $1 \mathrm{H}), 6.1(\mathrm{~m}, 2 \mathrm{H}) ;{ }^{13} \mathrm{C} \mathrm{NMR}\left(75 \mathrm{MHz}, \mathrm{CDCl}_{3}\right) \delta$ 154.9, 123.4, 72.2, 30.0, -9.3; HRMS (EI) $m / z 235.1037\left[\left(\mathrm{M}^{+}-\mathrm{CH}_{3}\right)\right.$ calcd for $\left.\mathrm{C}_{7} \mathrm{H}_{15} \mathrm{O}^{116} \mathrm{Sn} 235.1046\right]$.

Representative procedure for the use of $6 \mathrm{~mol} \%(E)-2-m e t h y l-4-($ trimethylstannyl)but-3en-2-ol as the tin source. Preparation of 2-methyl-6-phenyl-hexa-3,5-dien-2-ol (16) (Control Experiment). Following the above procedure outlined for Table 1, (E)-2-methyl-4(trimethylstannyl)but-3-en-2-ol (34) (15.0 mg, $0.06 \mathrm{mmol}),(E)-\beta$-bromostyrene (275 mg, 1.5 mmol) and 2-methyl-but-3-yn-2-ol (1) $(0.094 \mathrm{~mL}, 0.94 \mathrm{mmol})$ after column chromatography [silica gel, 90:10 hexane/EtOAc] 2-methyl-6-phenyl-hexa-3,5-dien-2-ol (16) (181 mg, 96\%) was afforded as an oil. For spectroscopic data see above. 


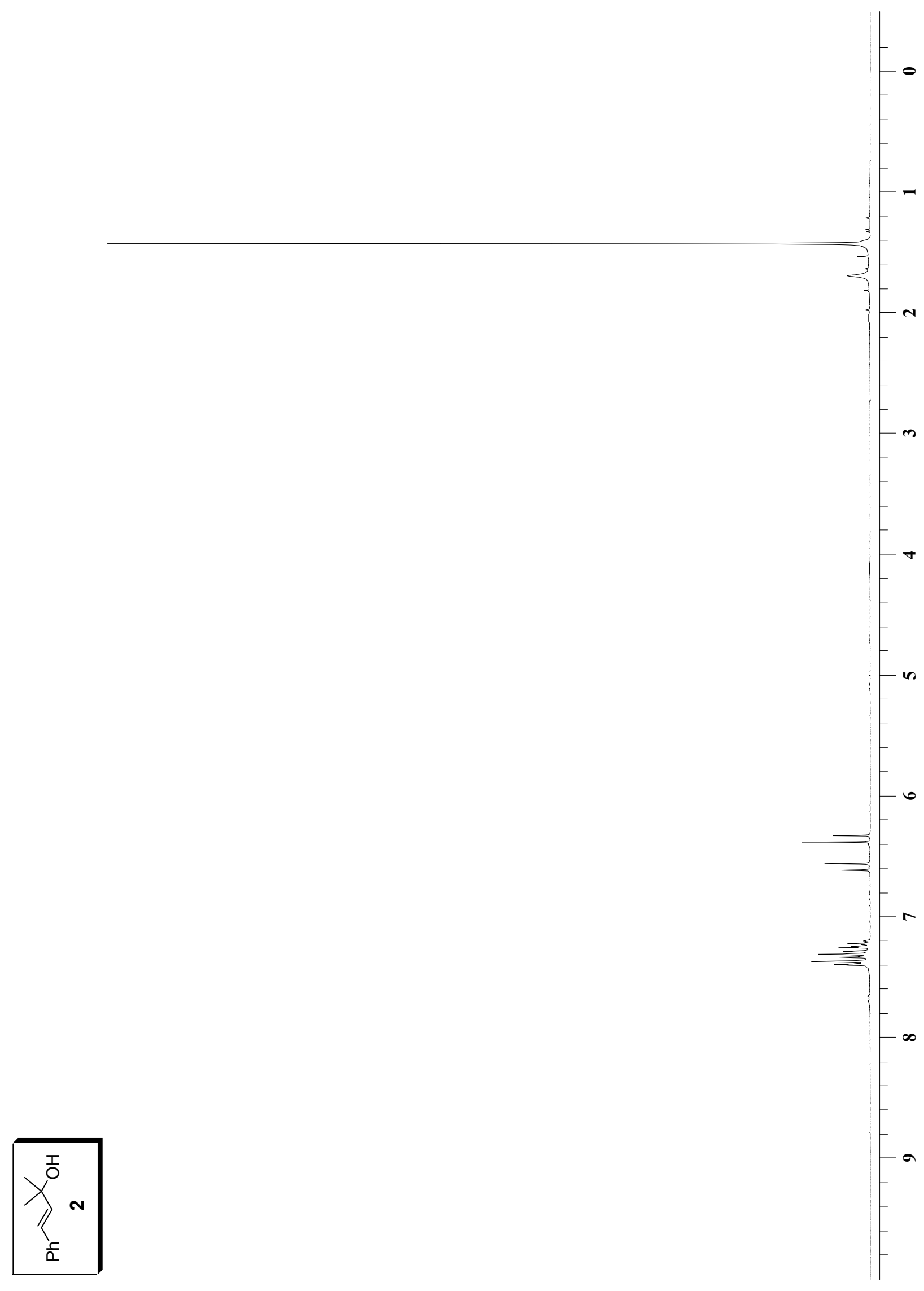




$$
.1
$$




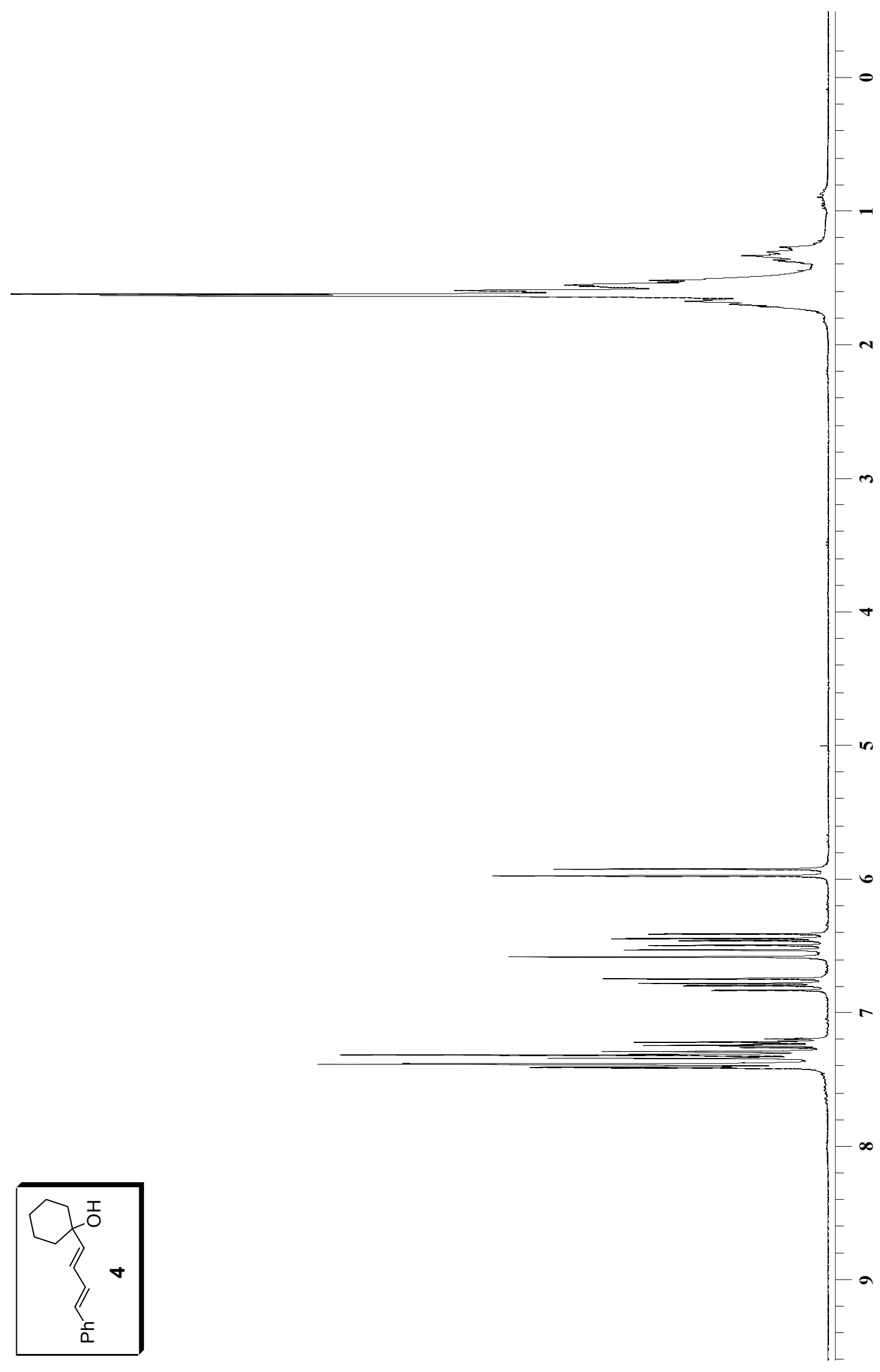




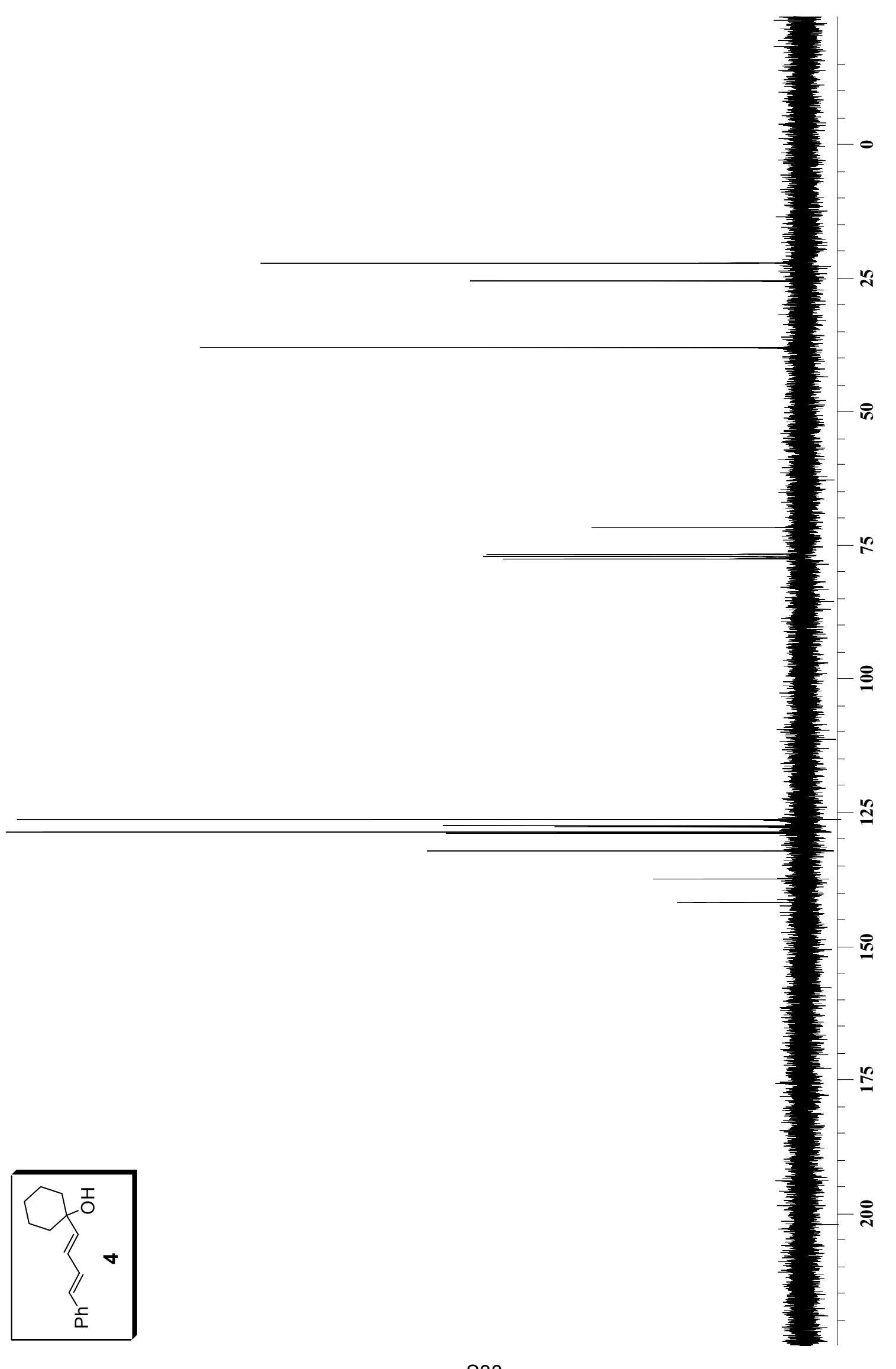




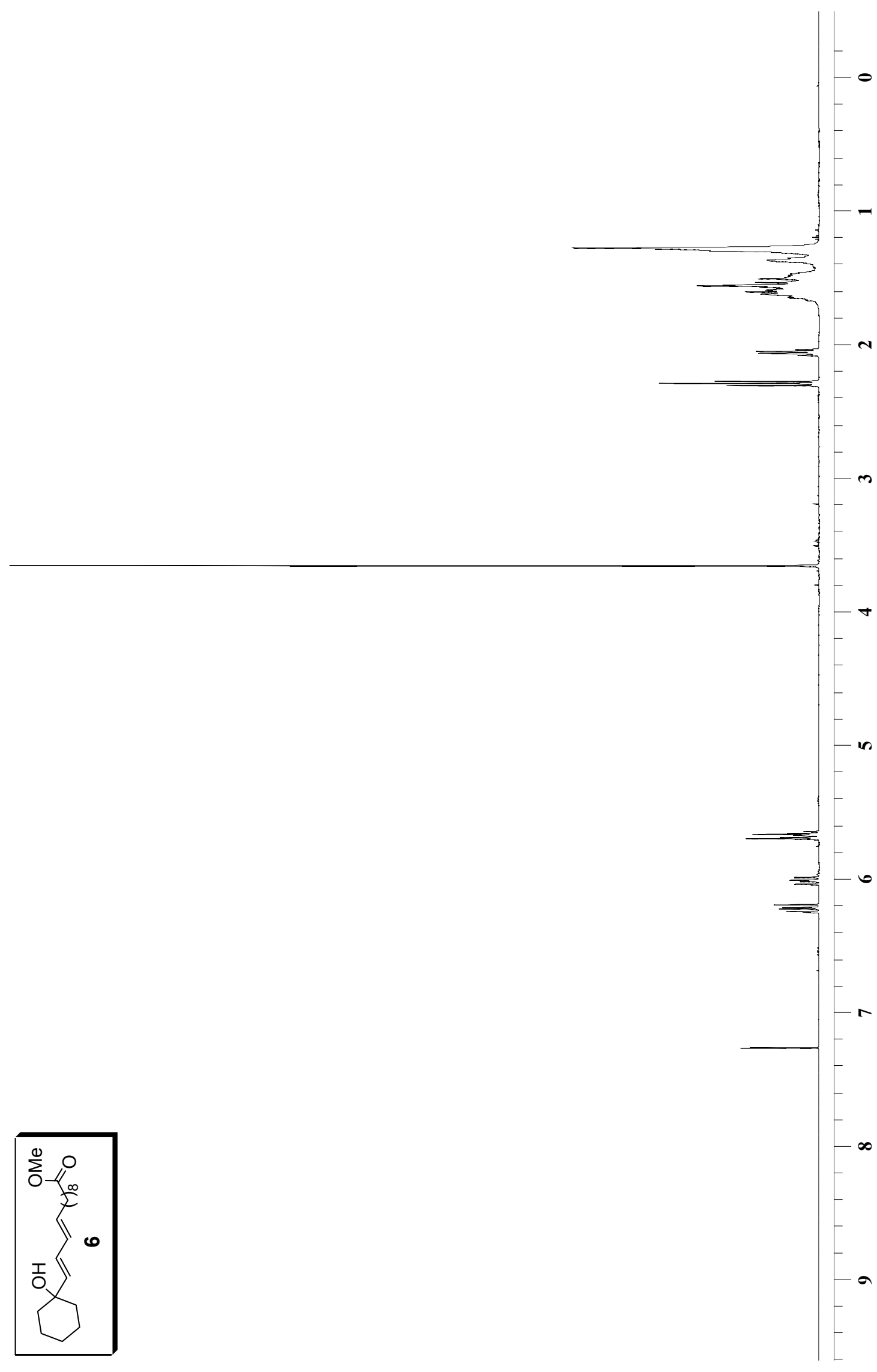




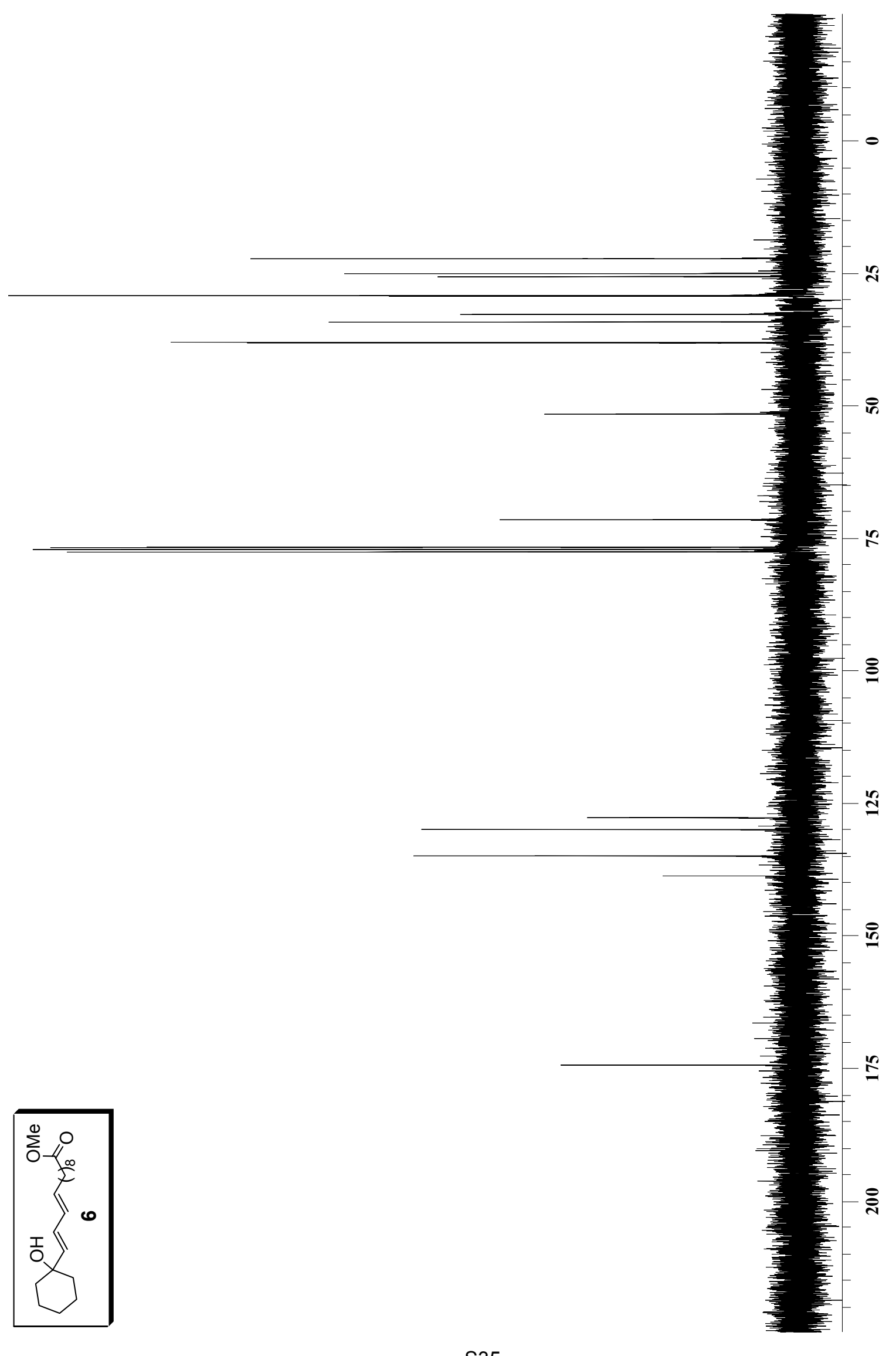




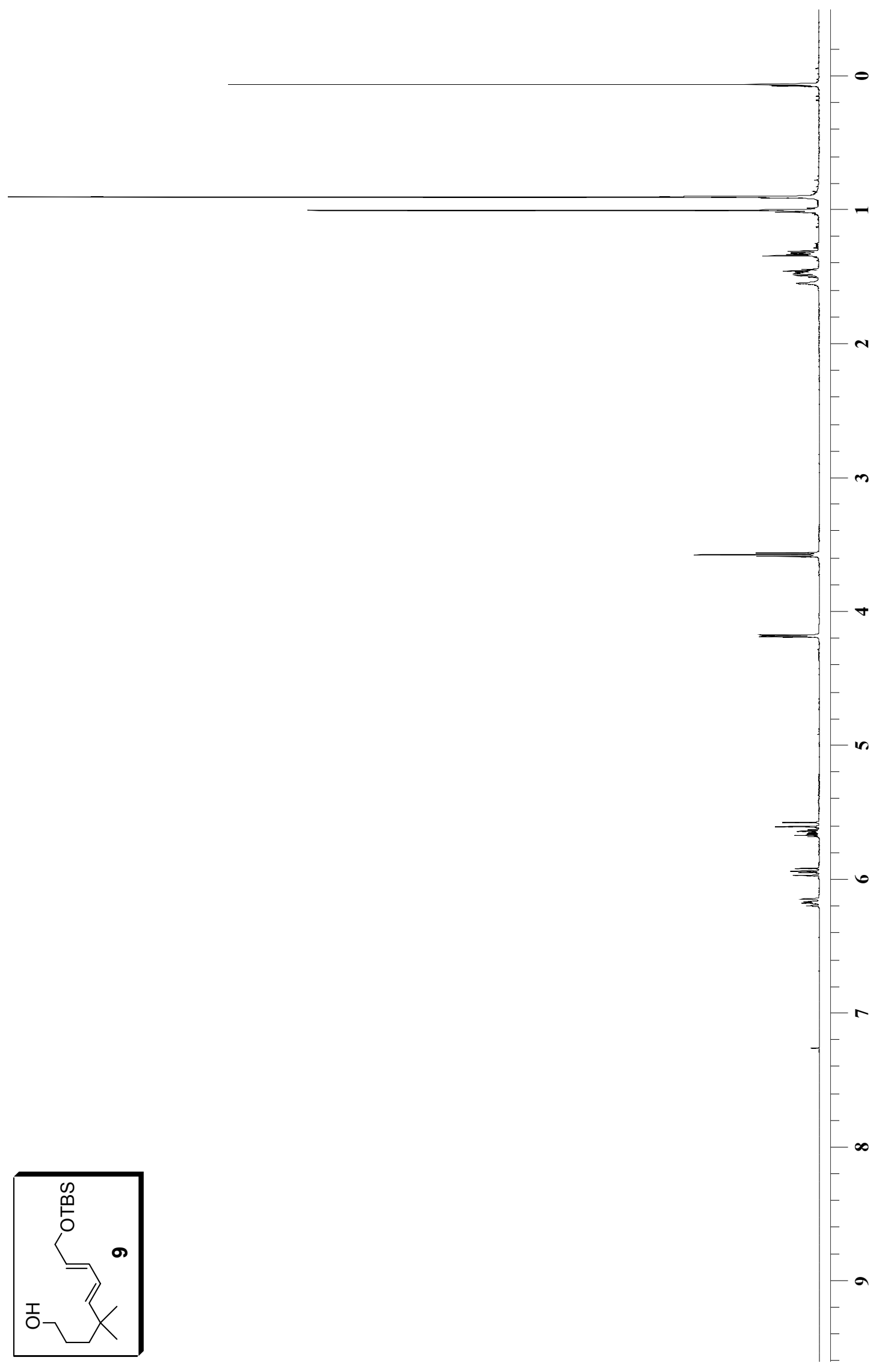




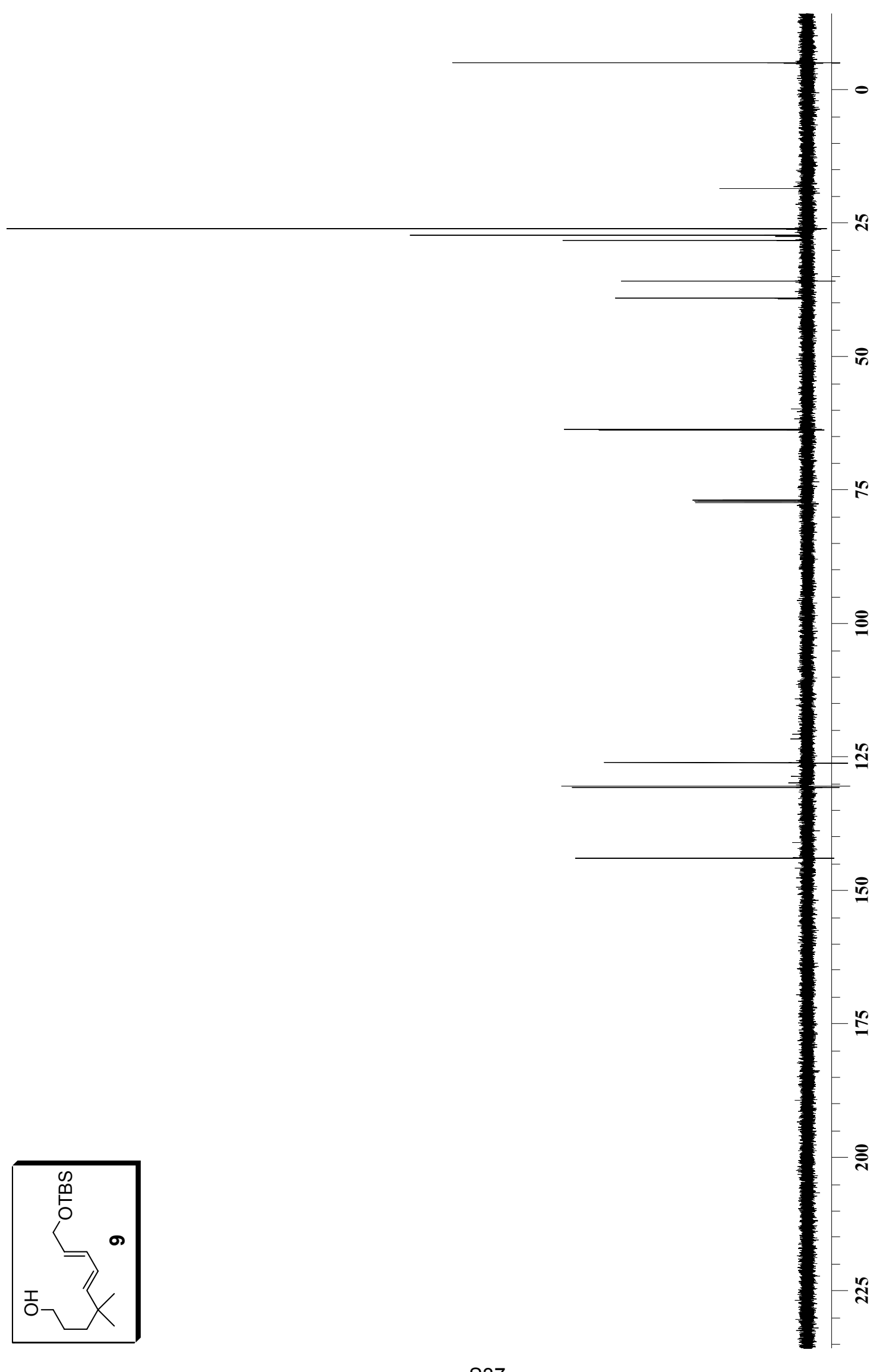




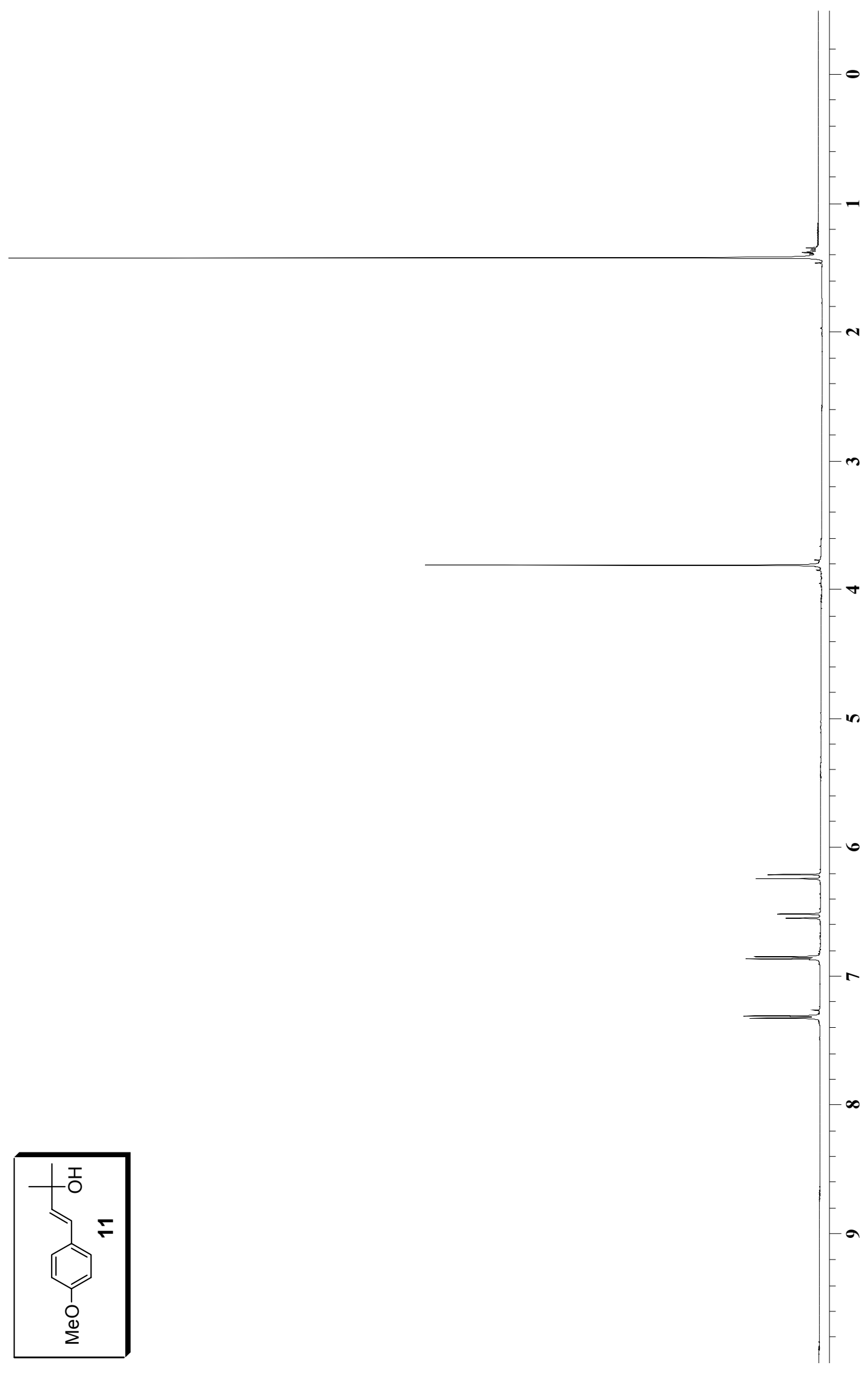



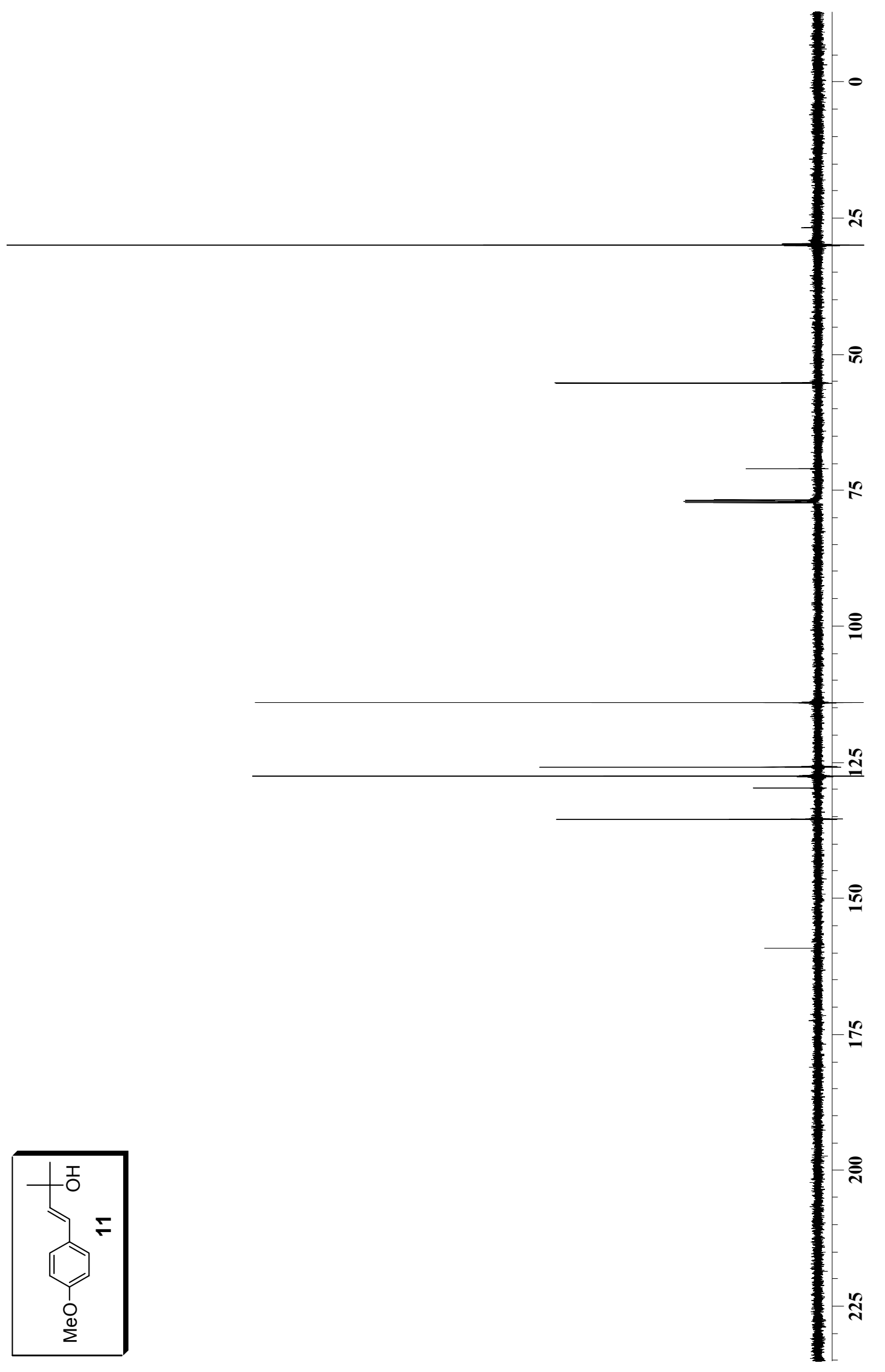


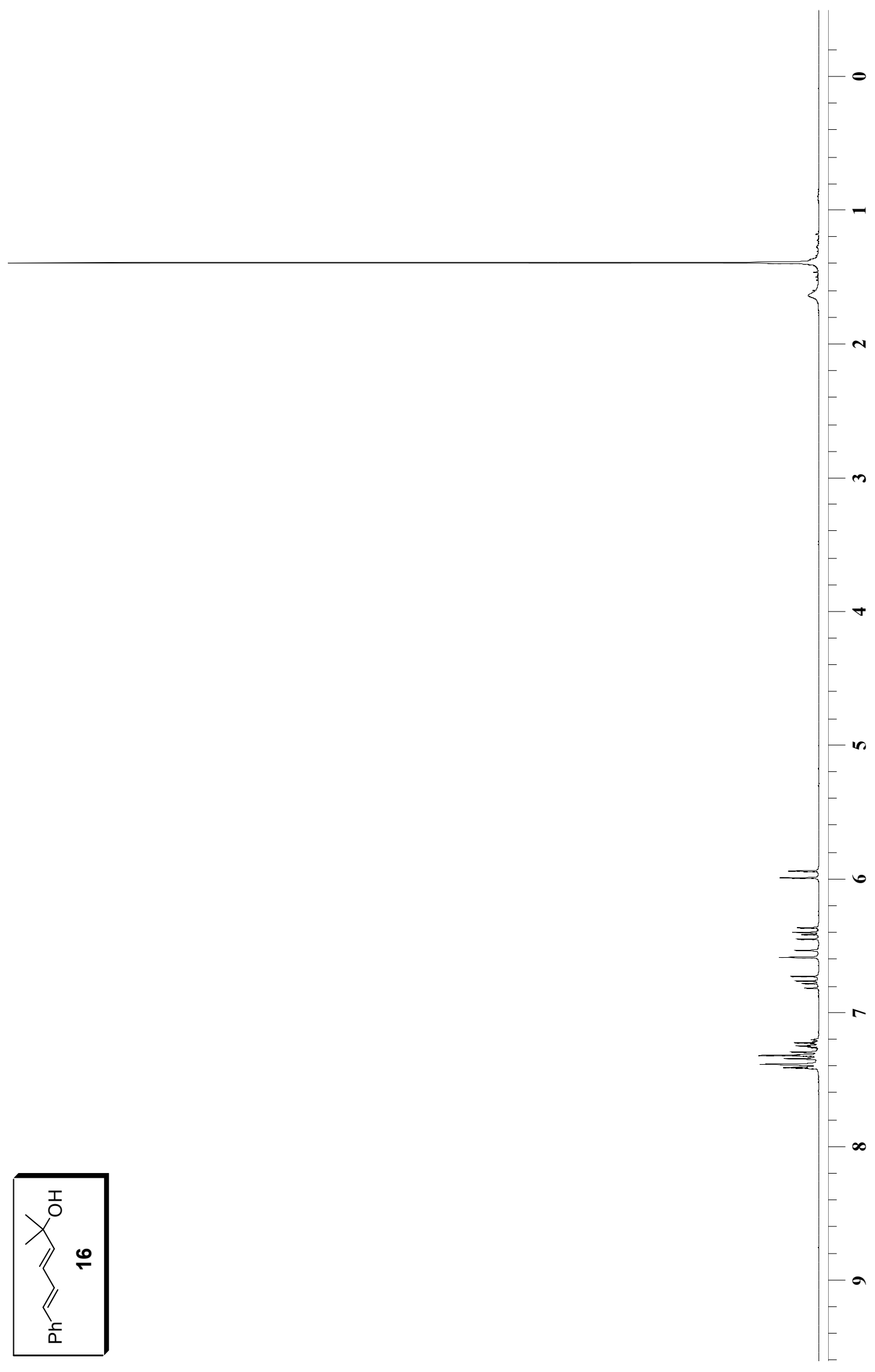




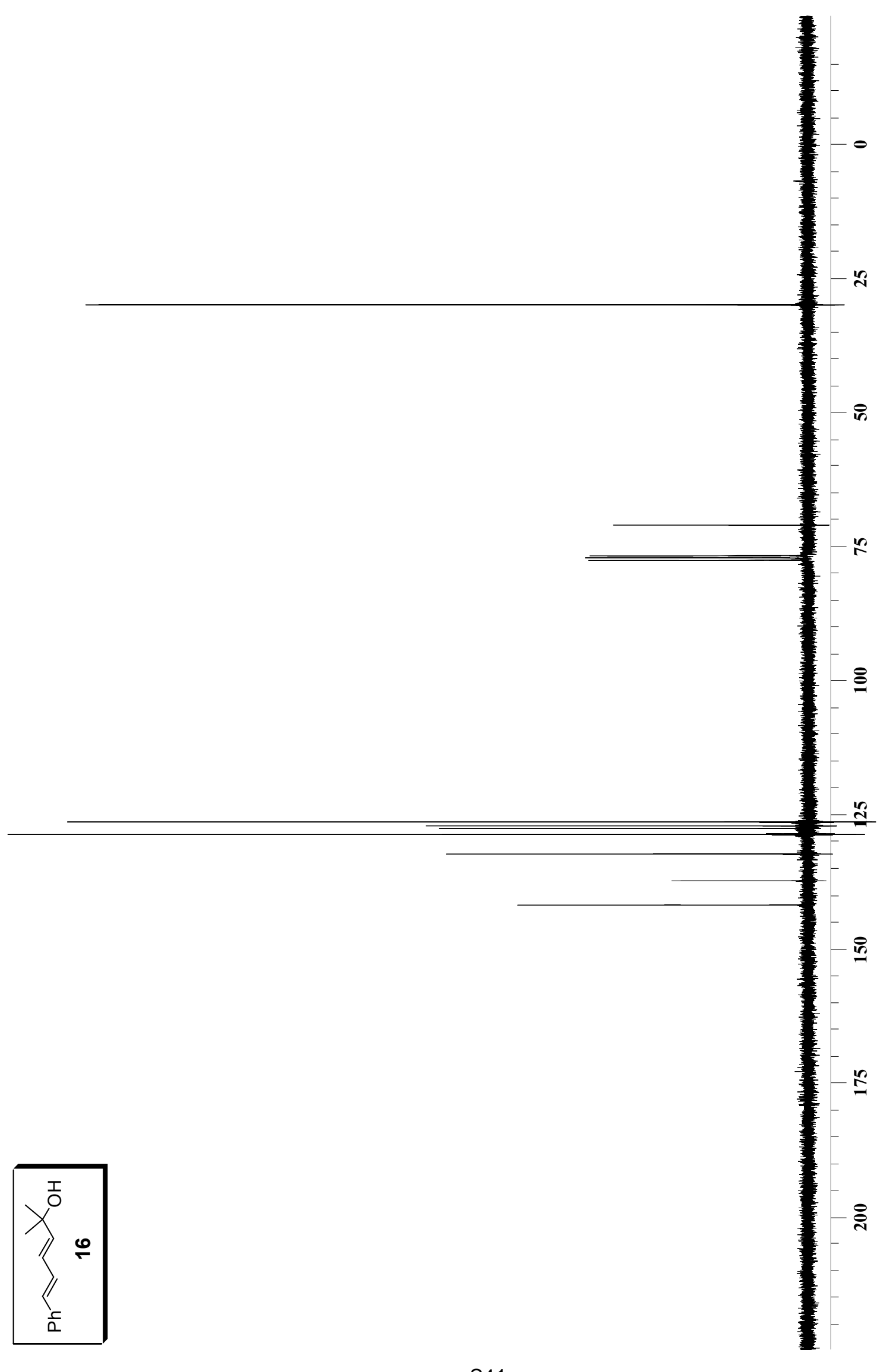




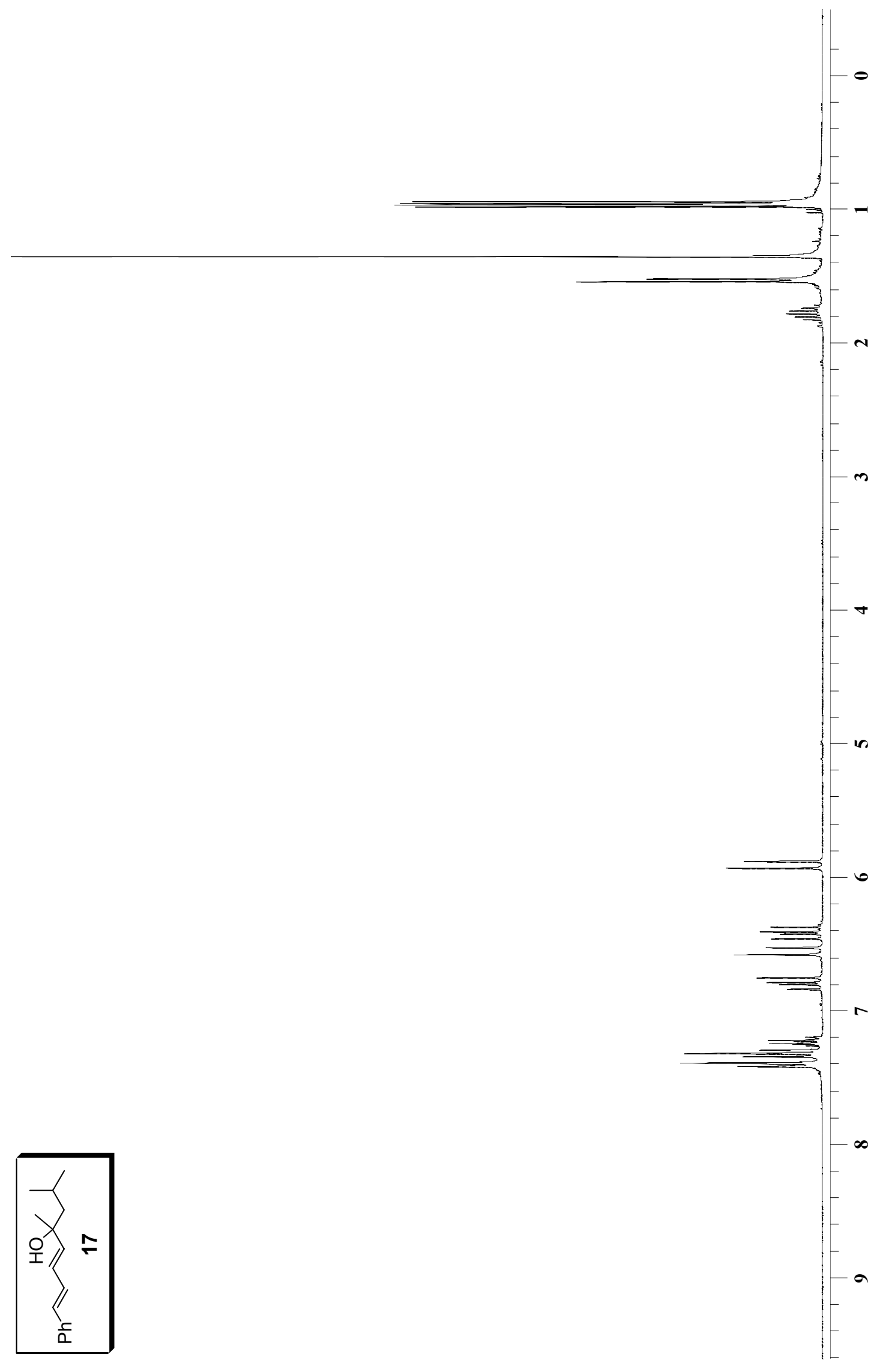




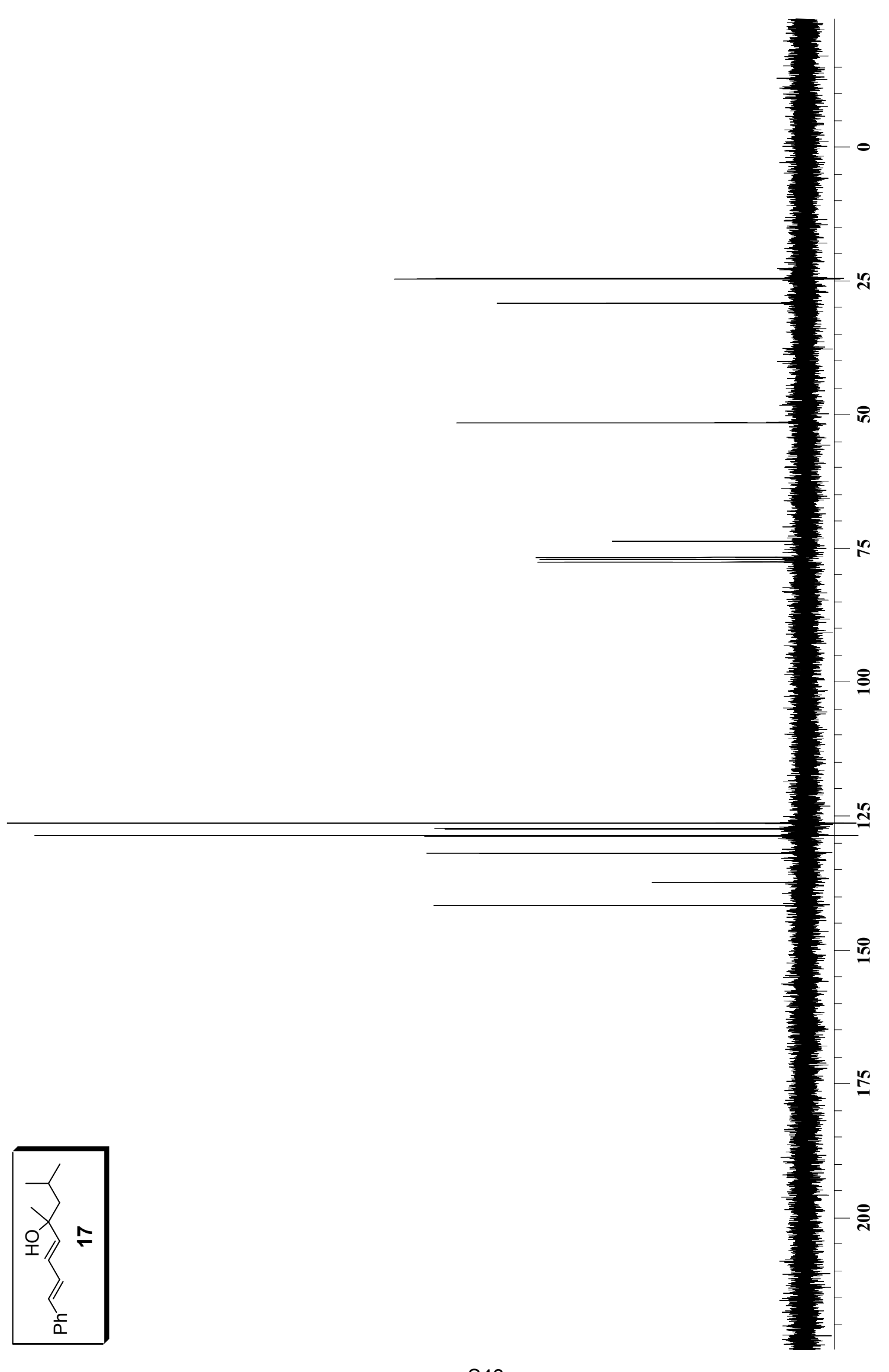




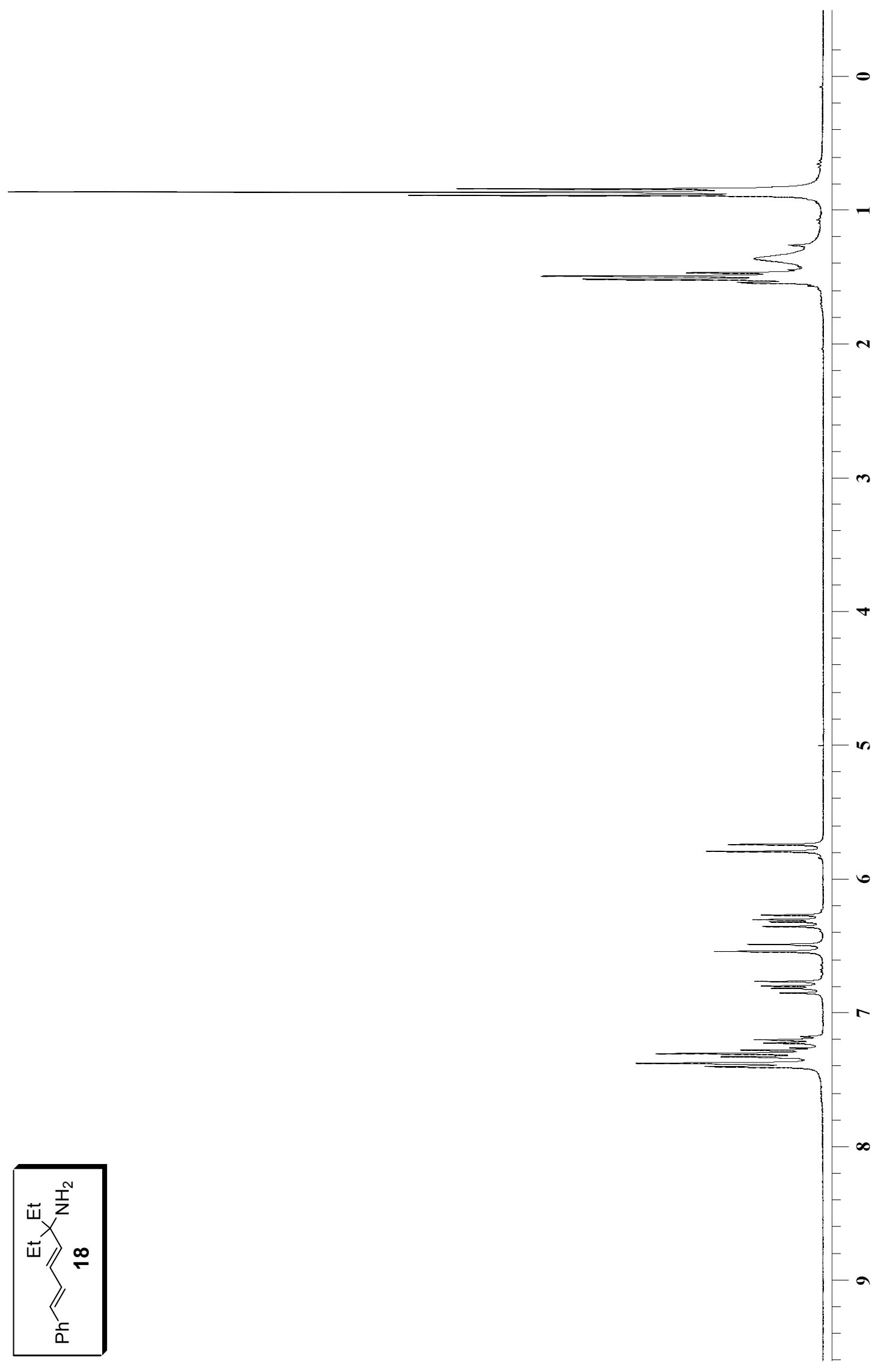




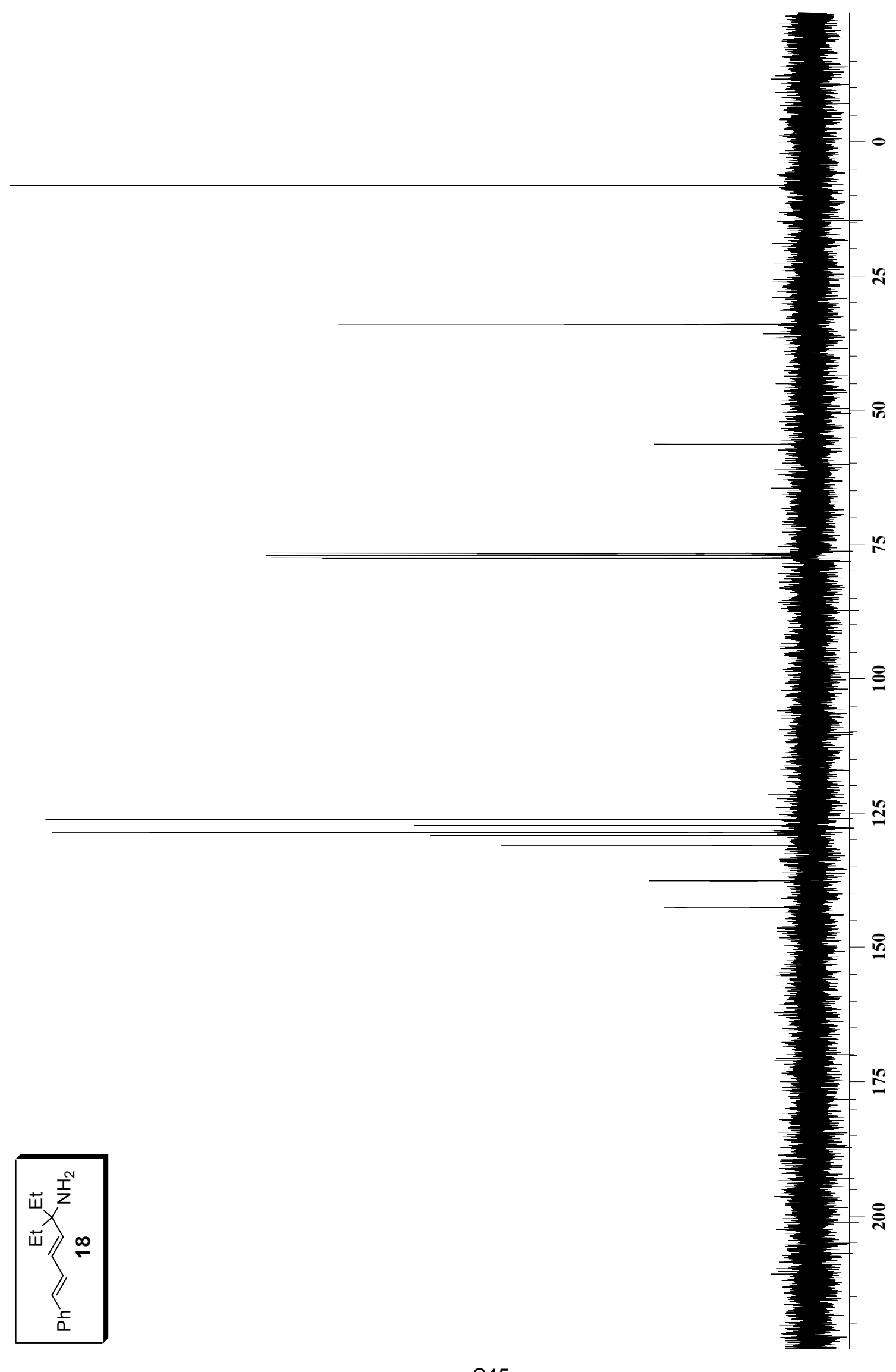




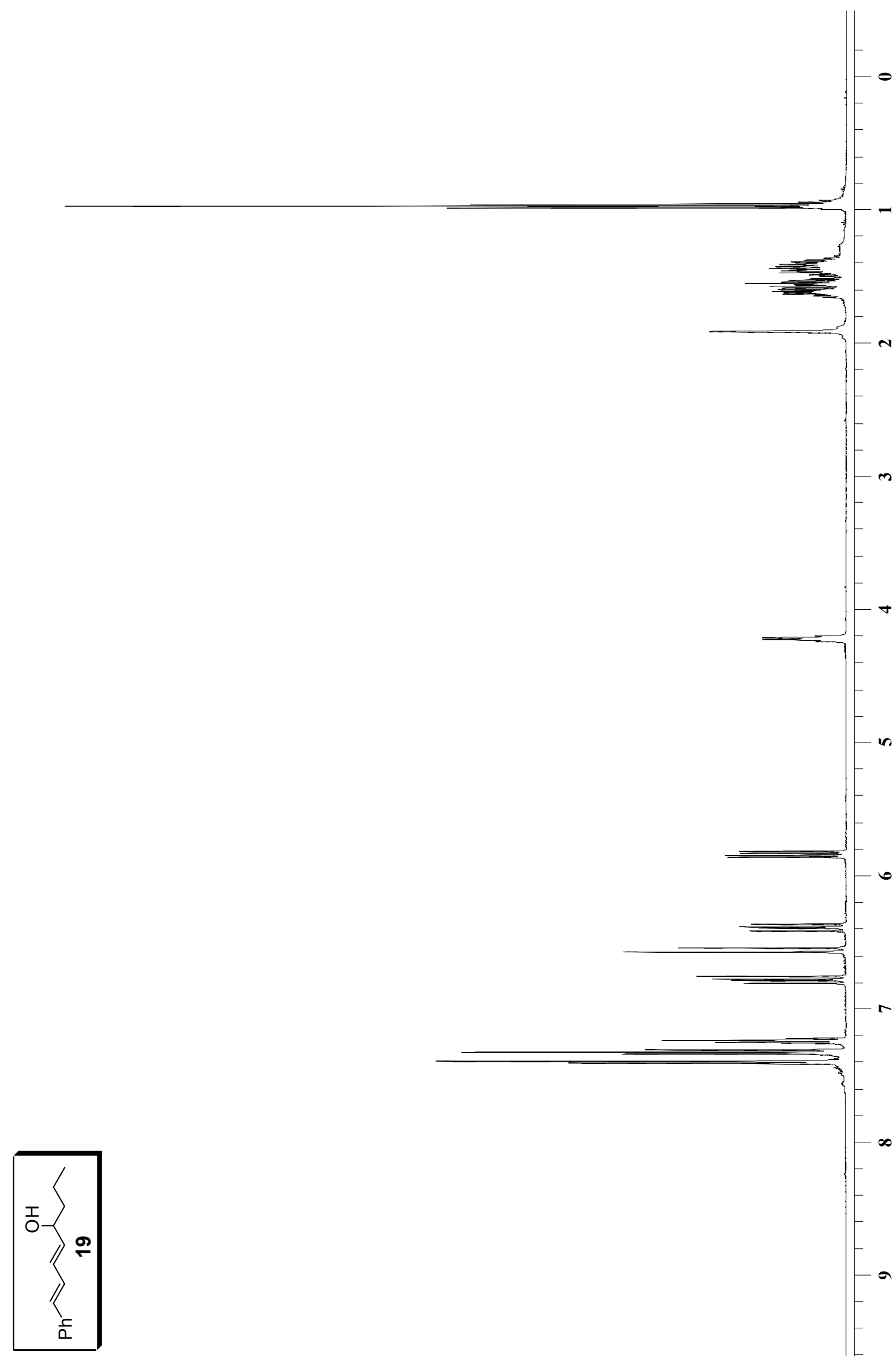




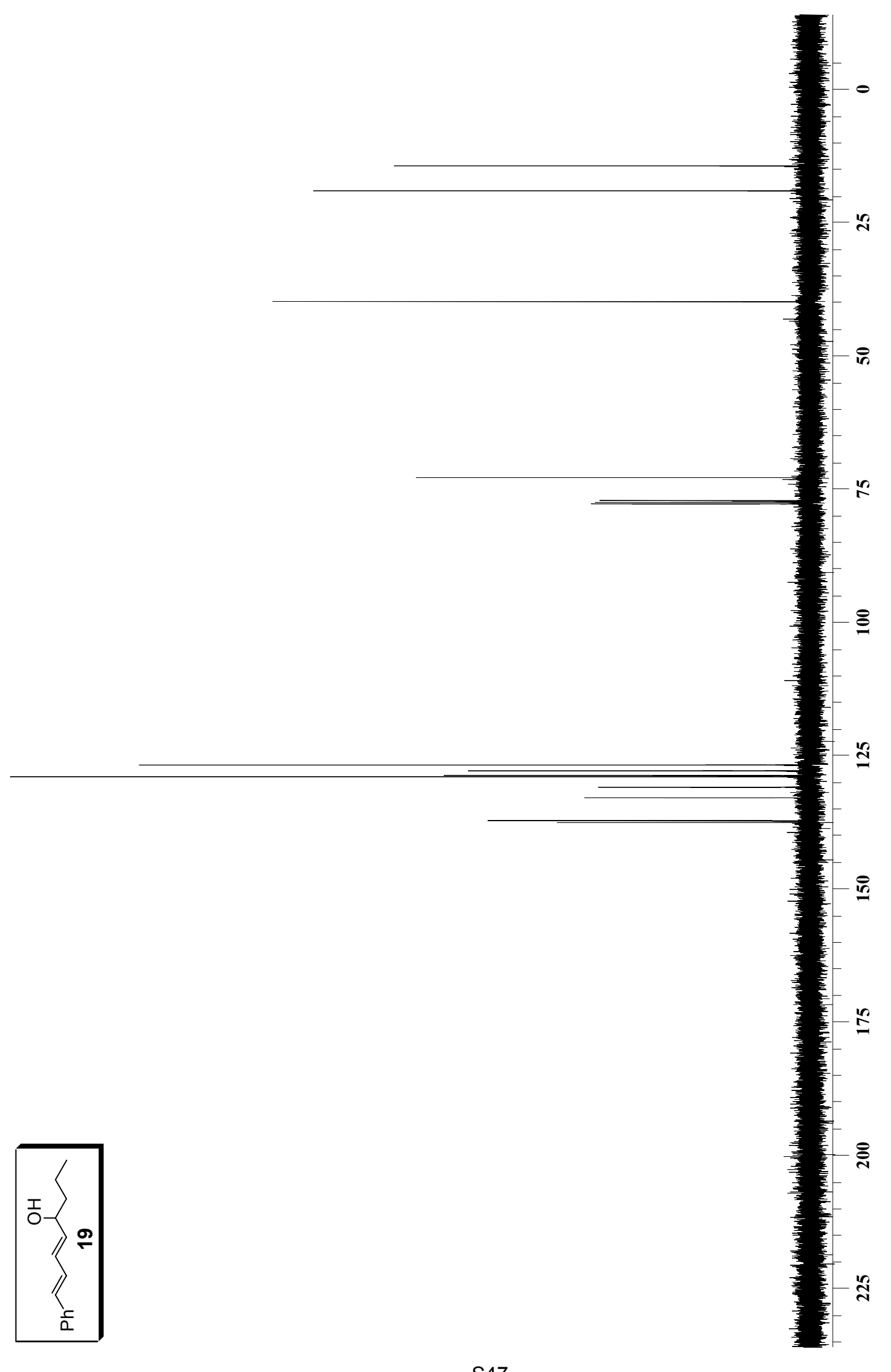




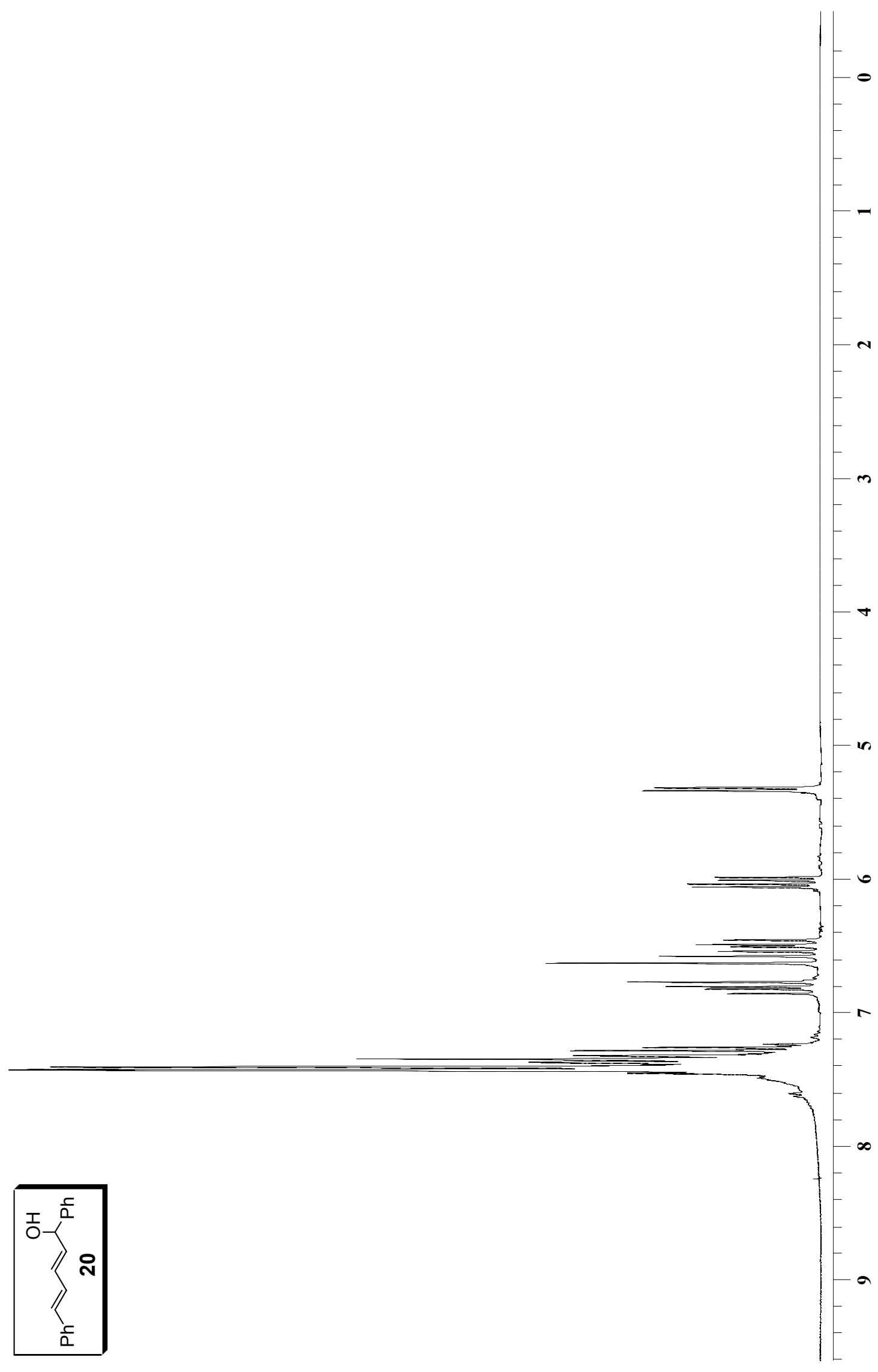




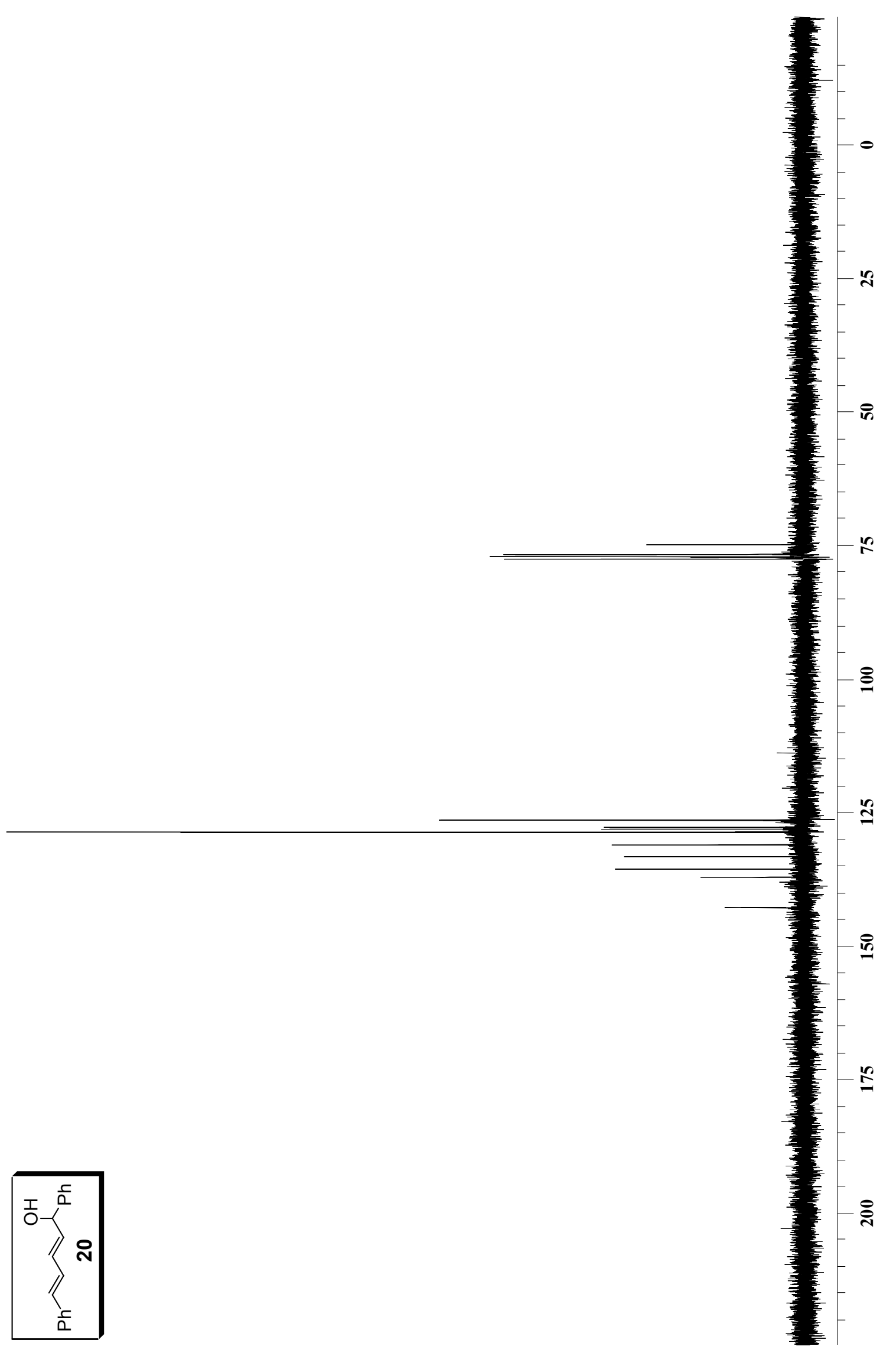




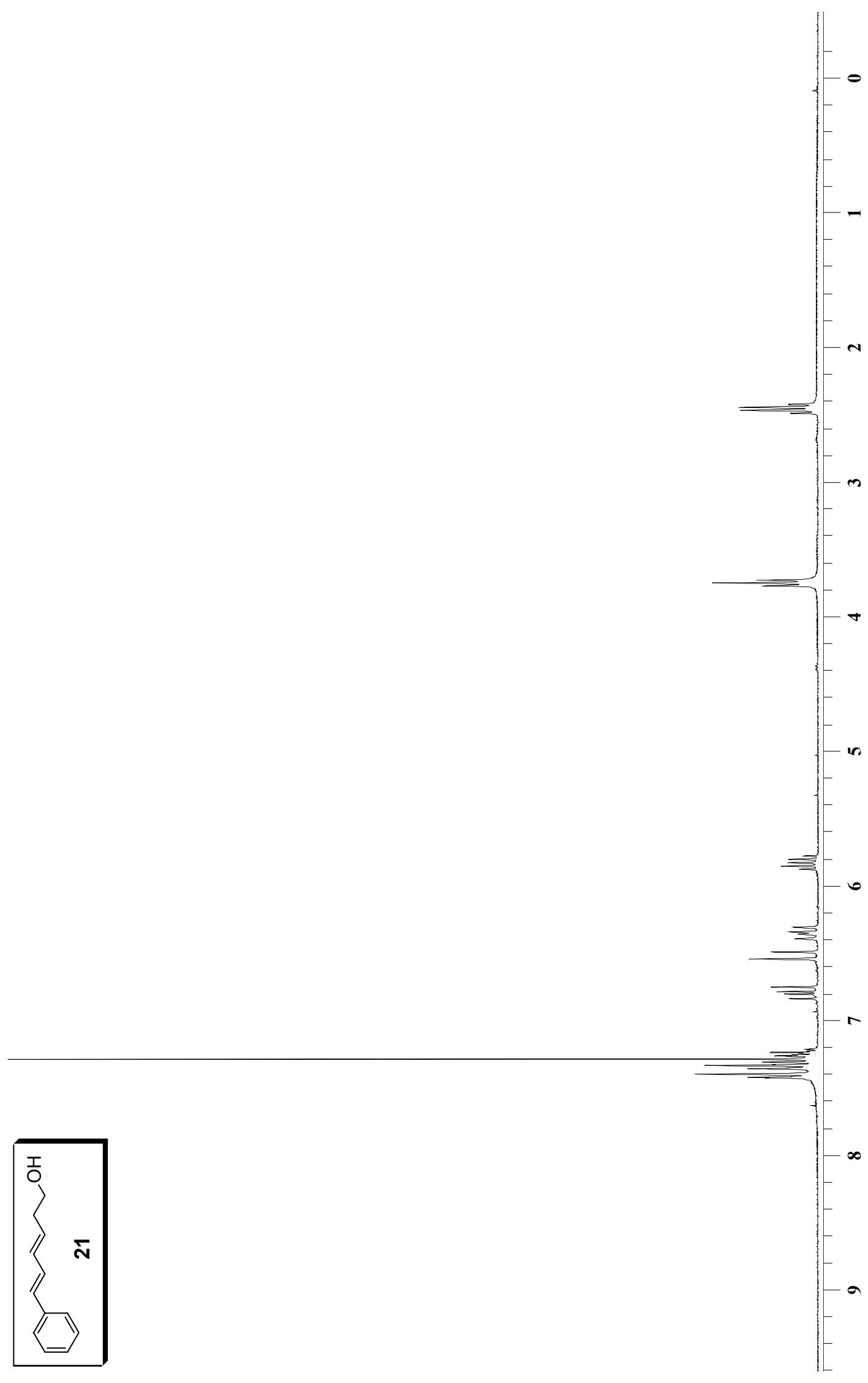




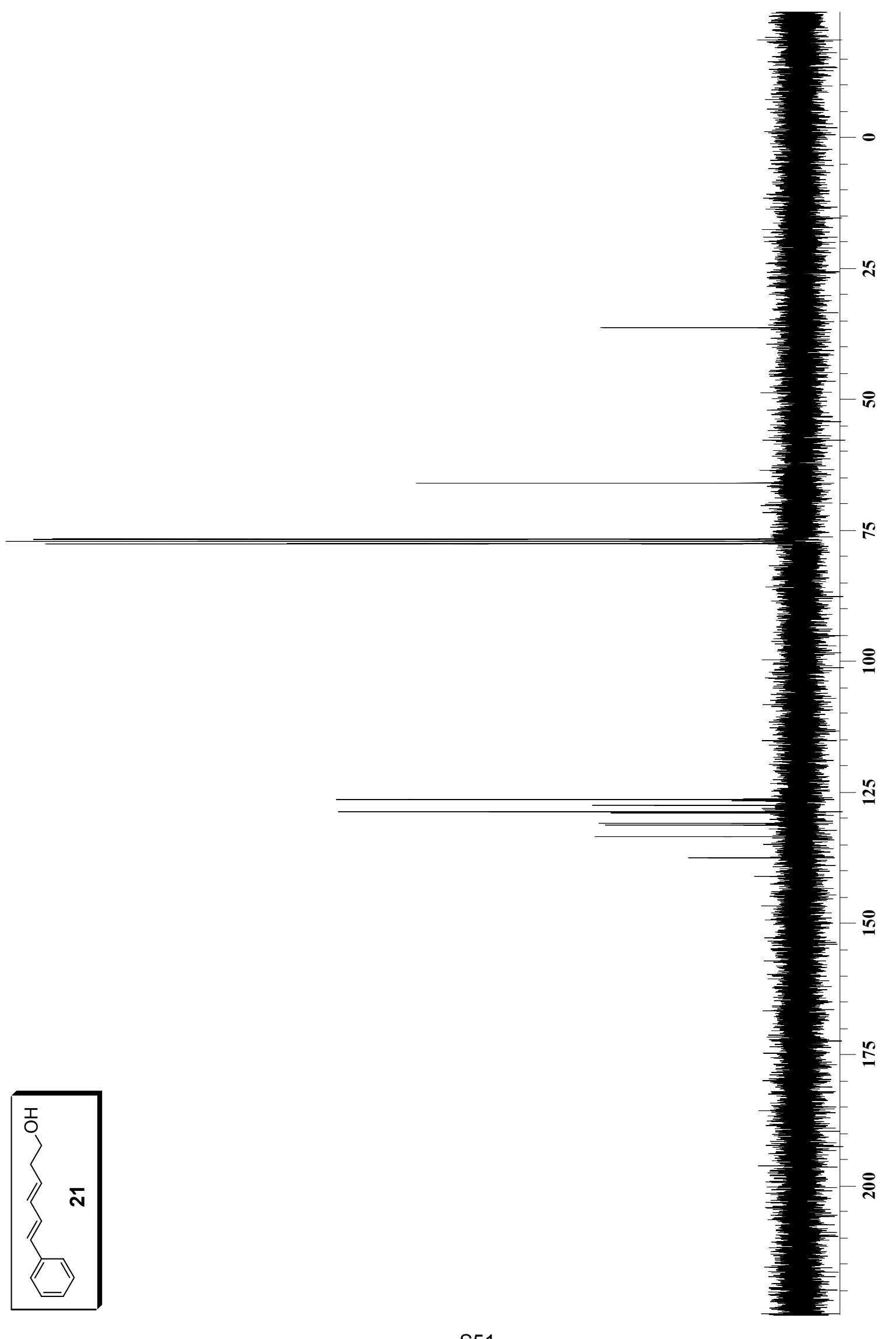




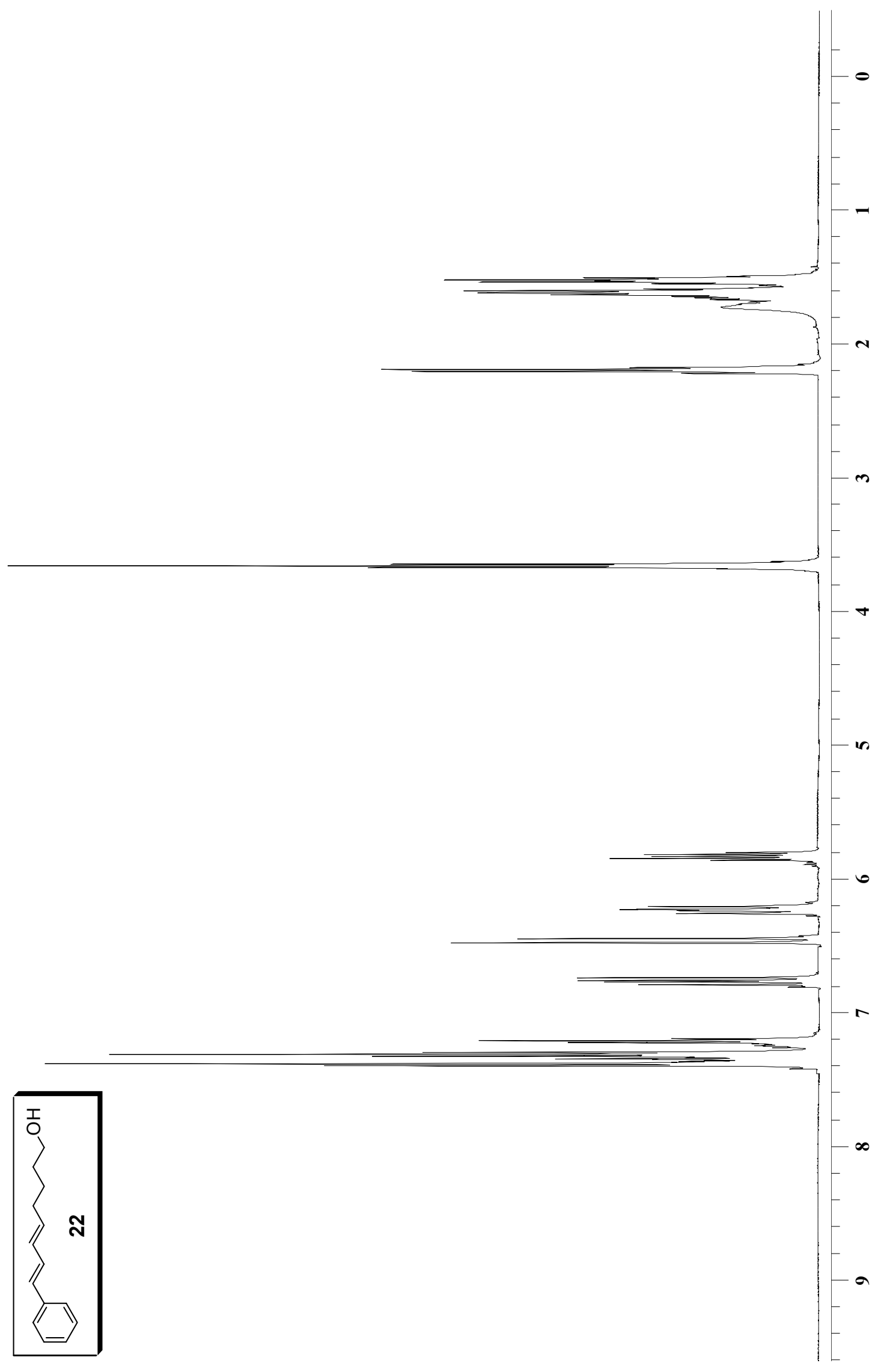




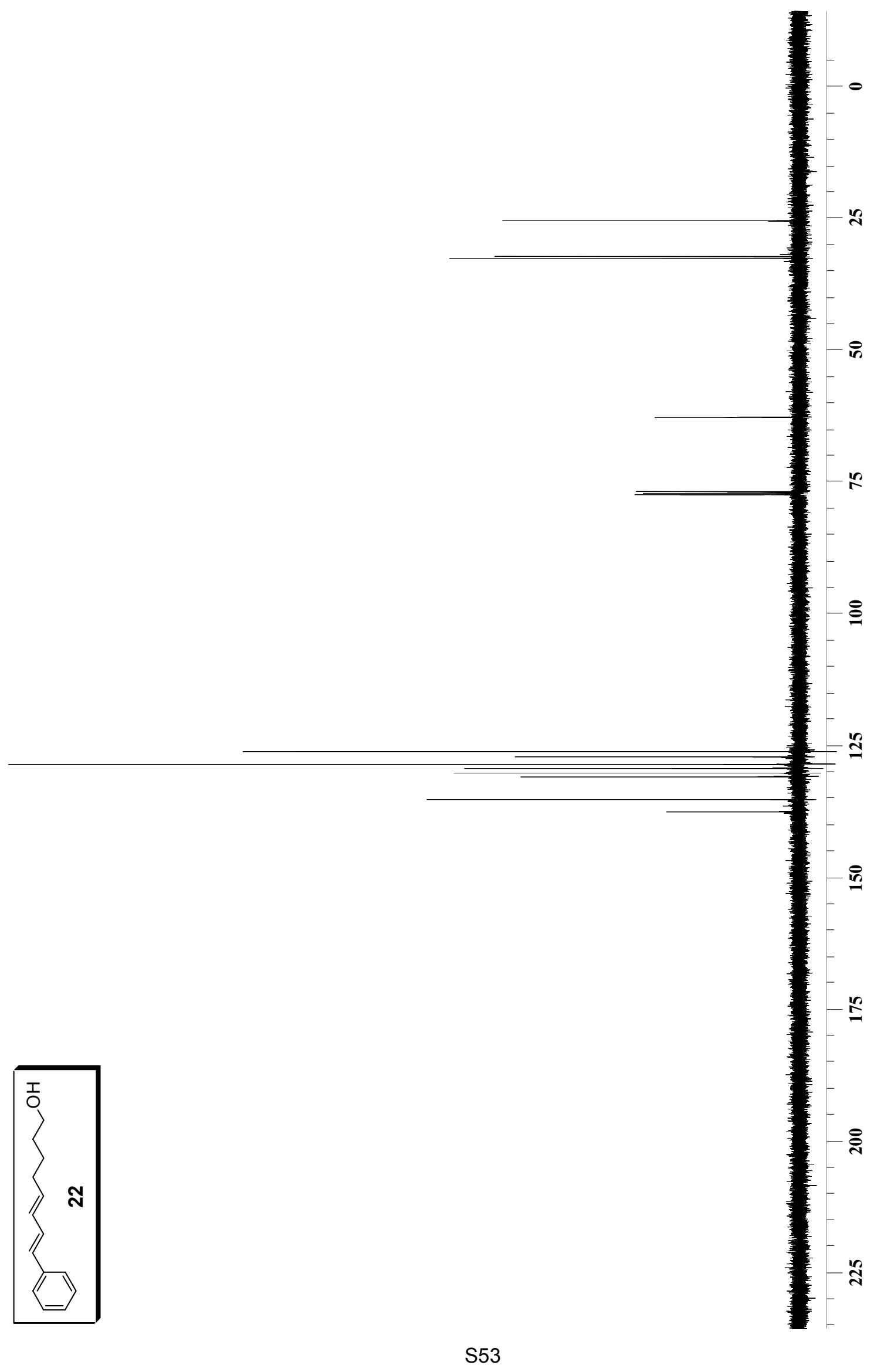




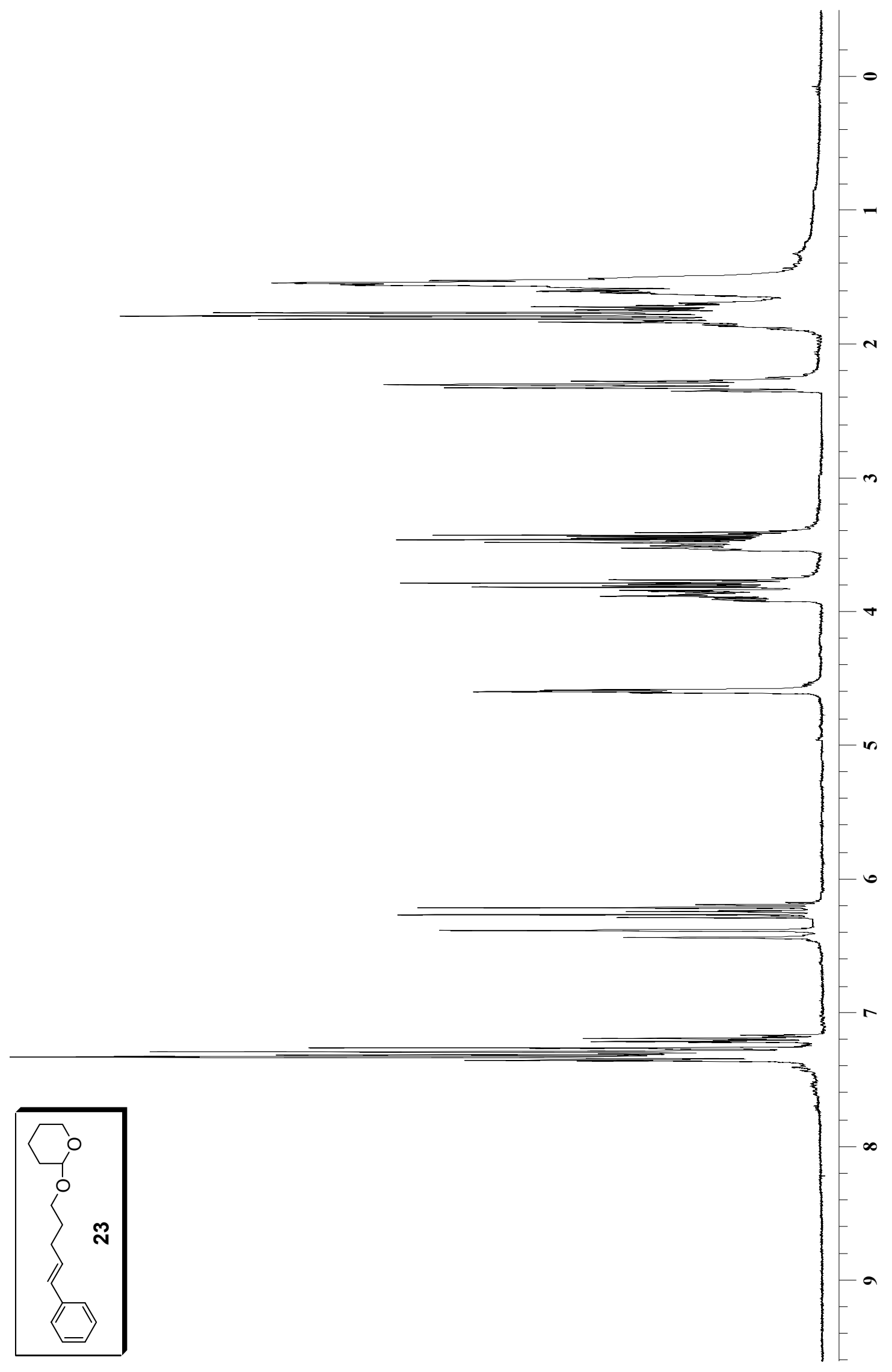




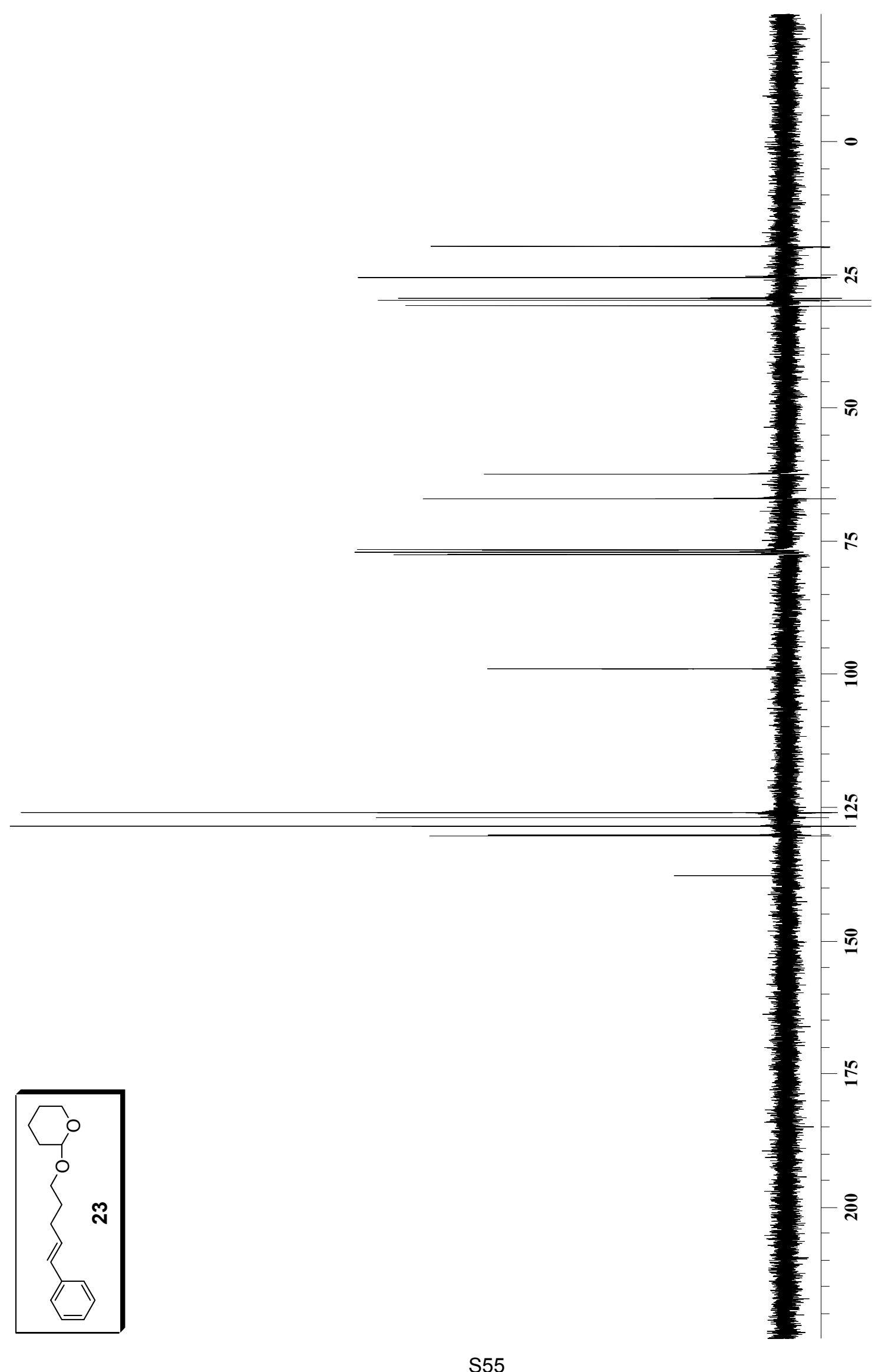




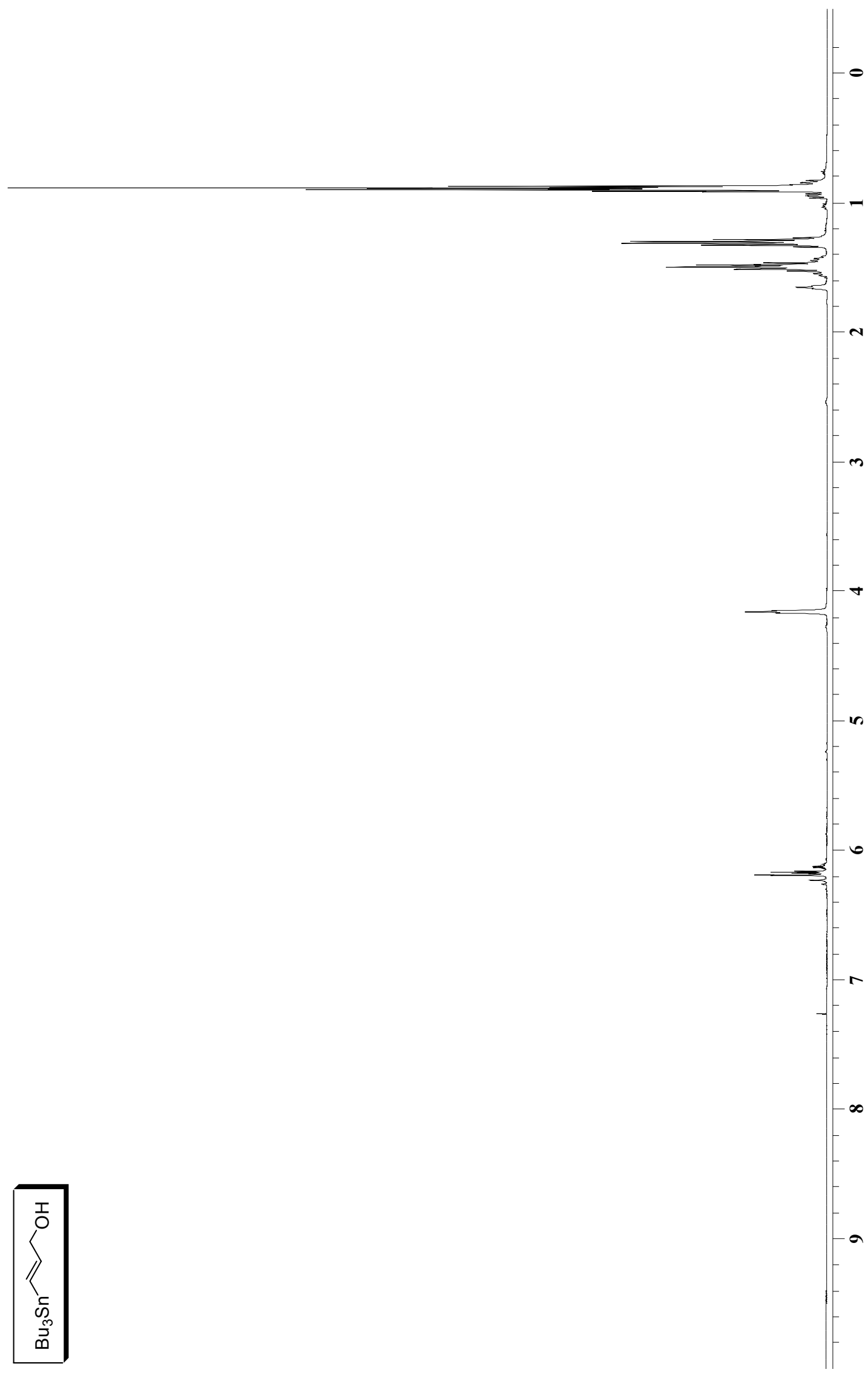




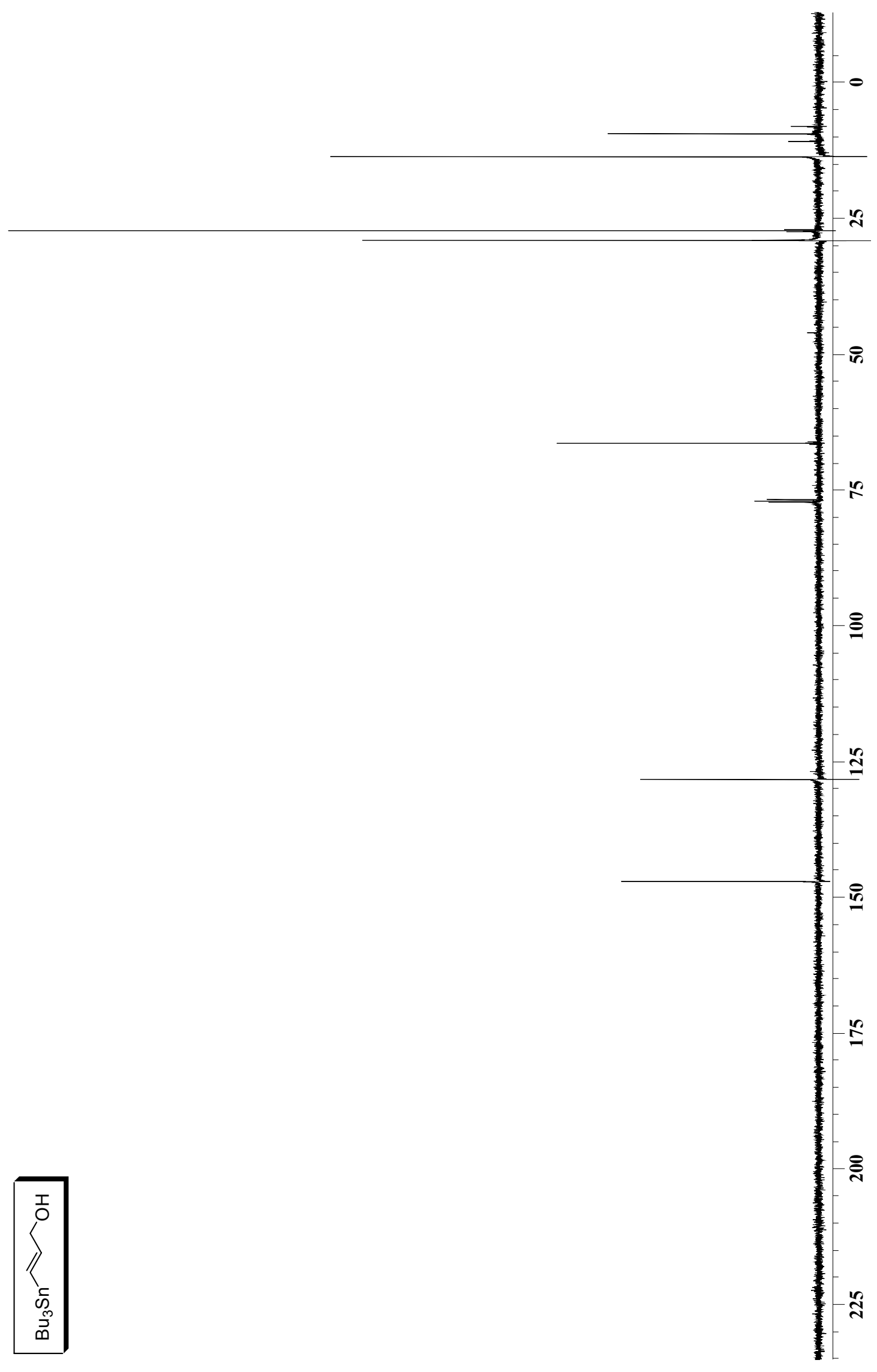




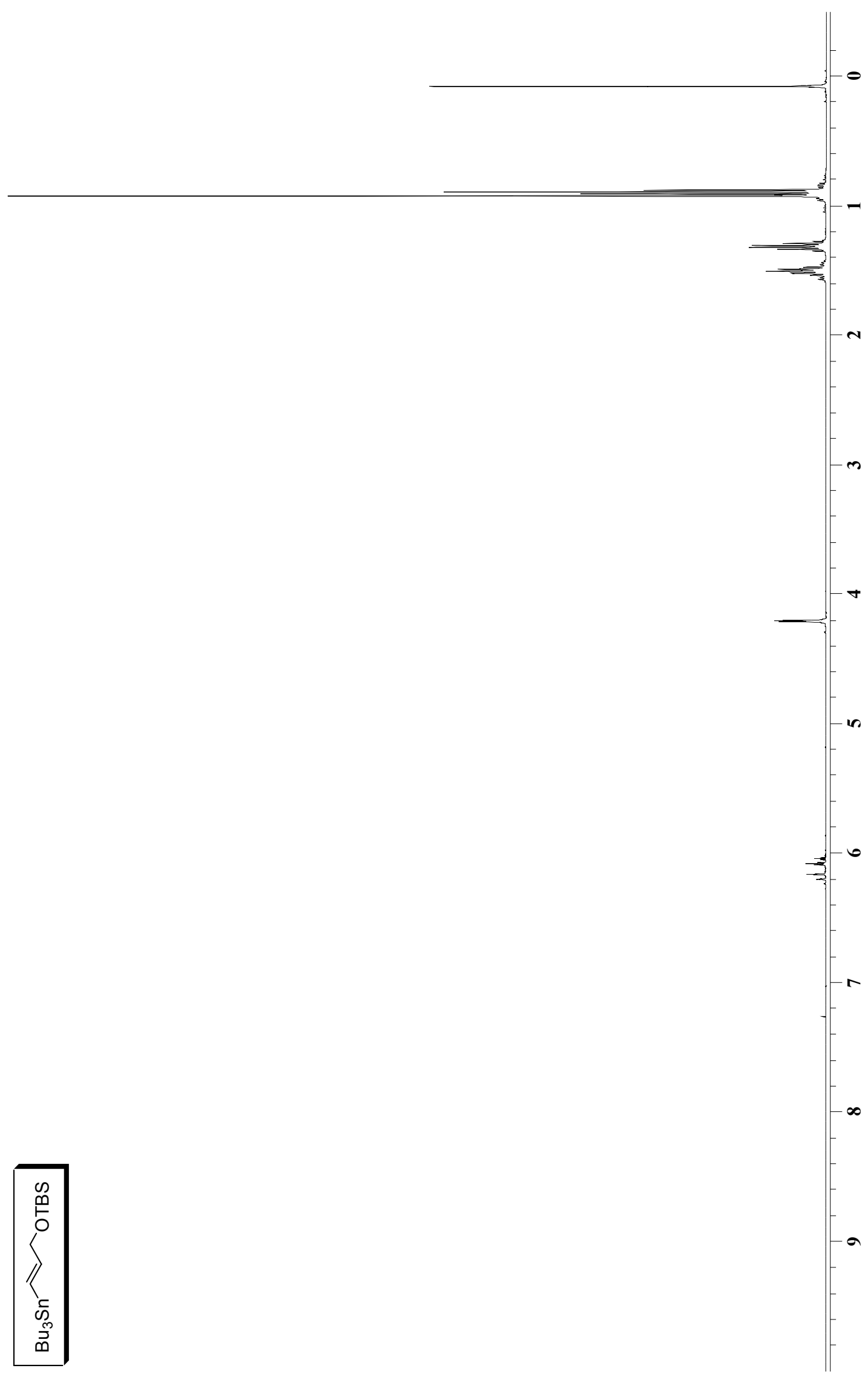




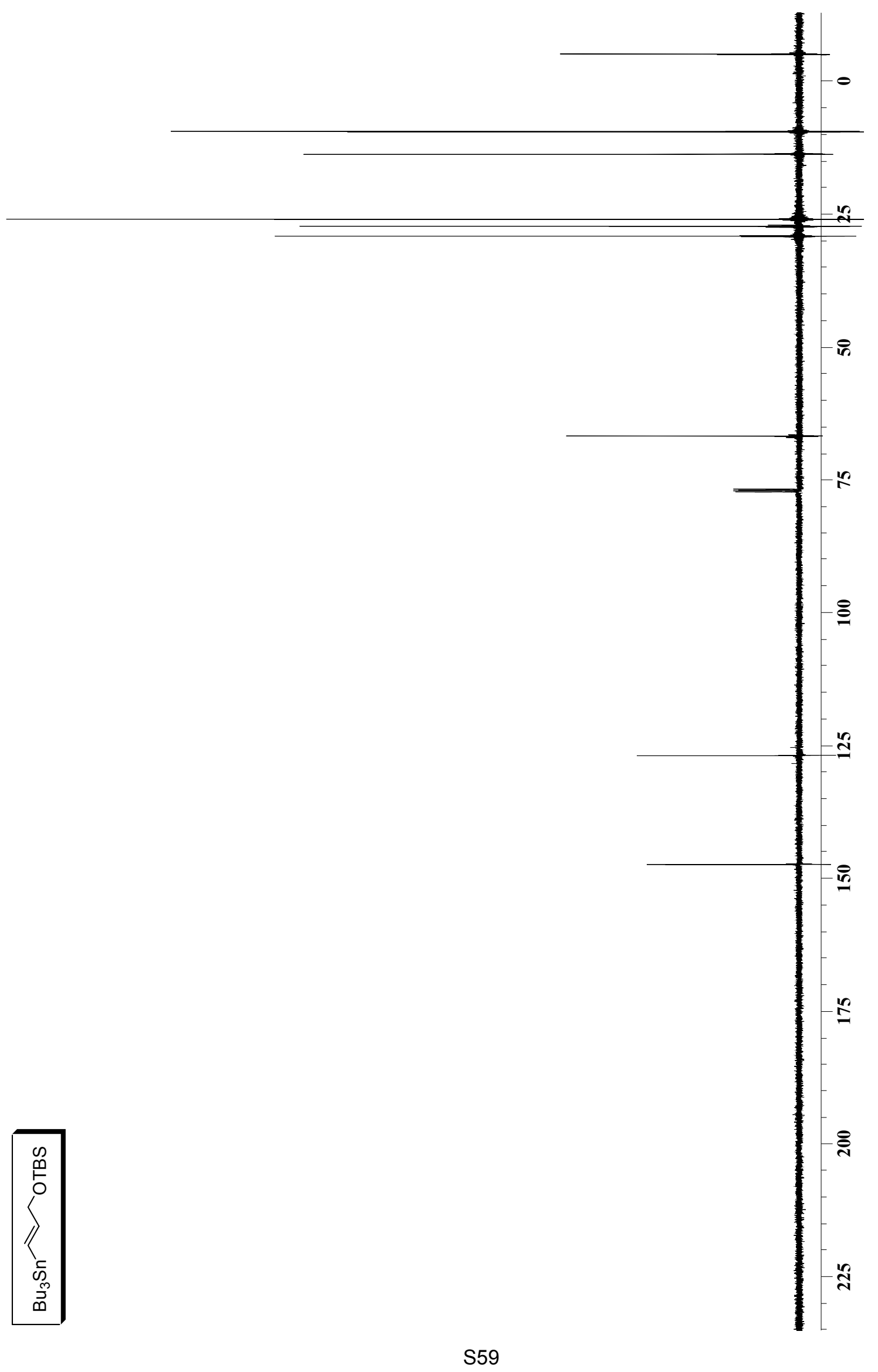




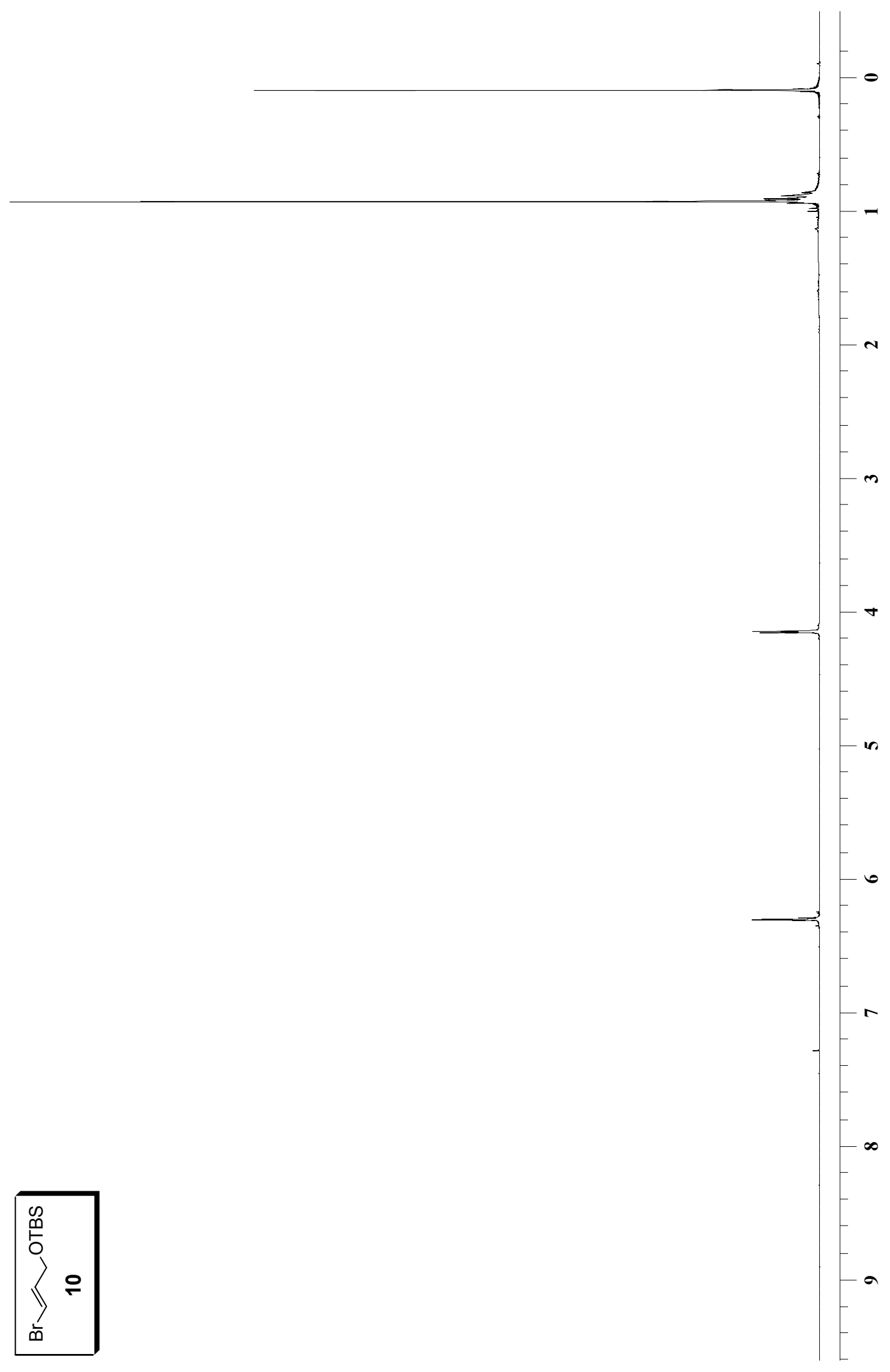




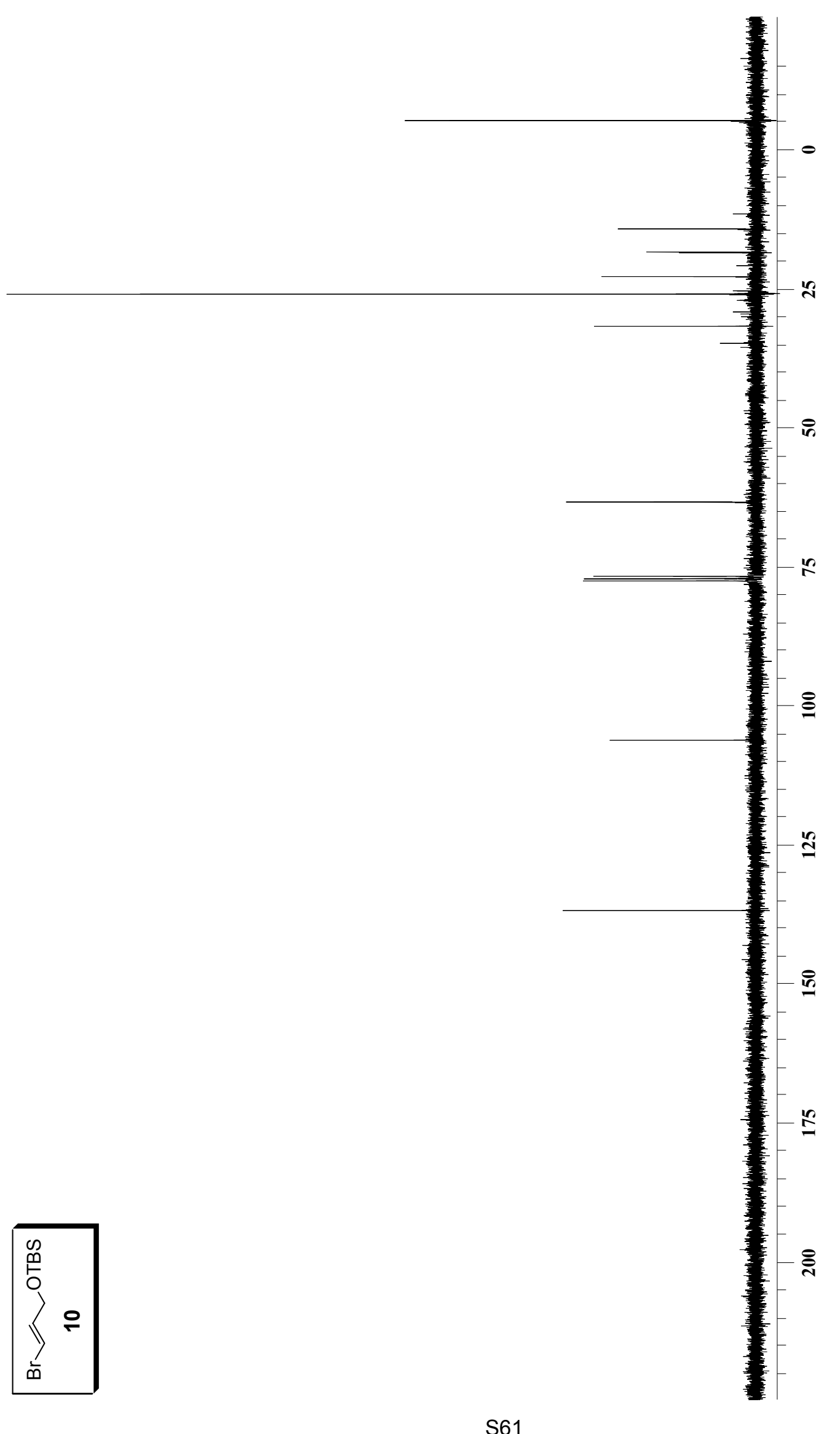




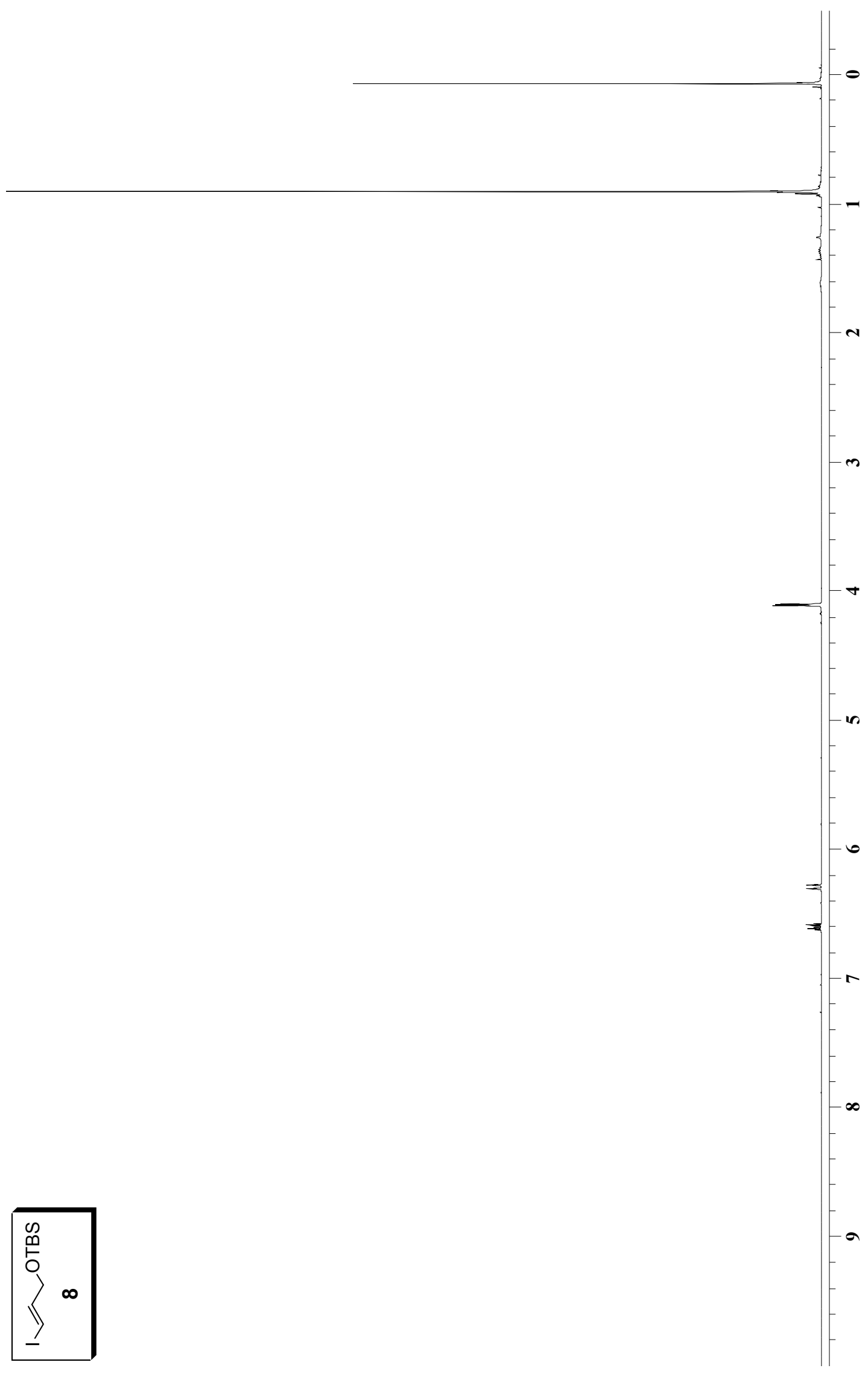




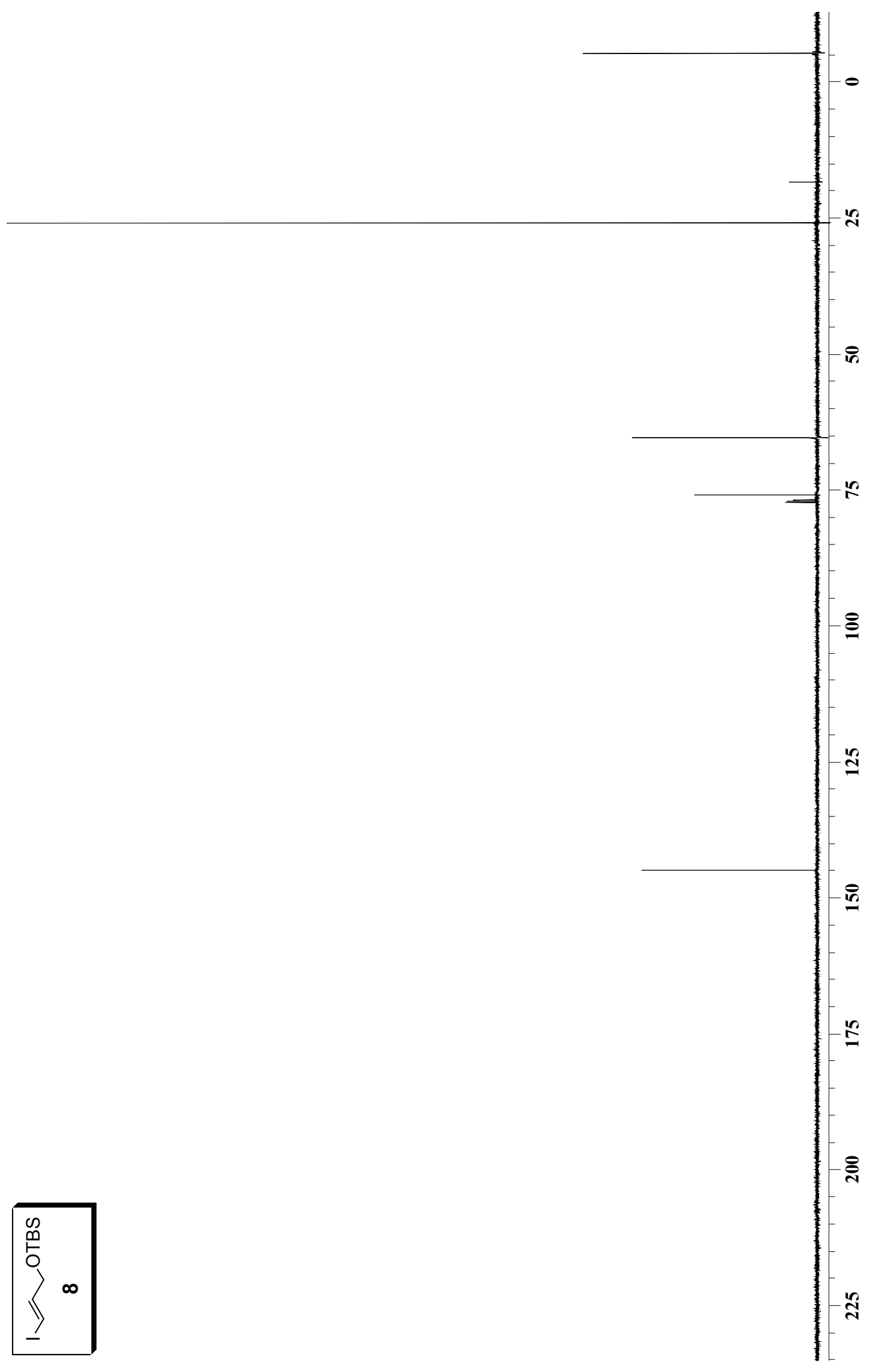




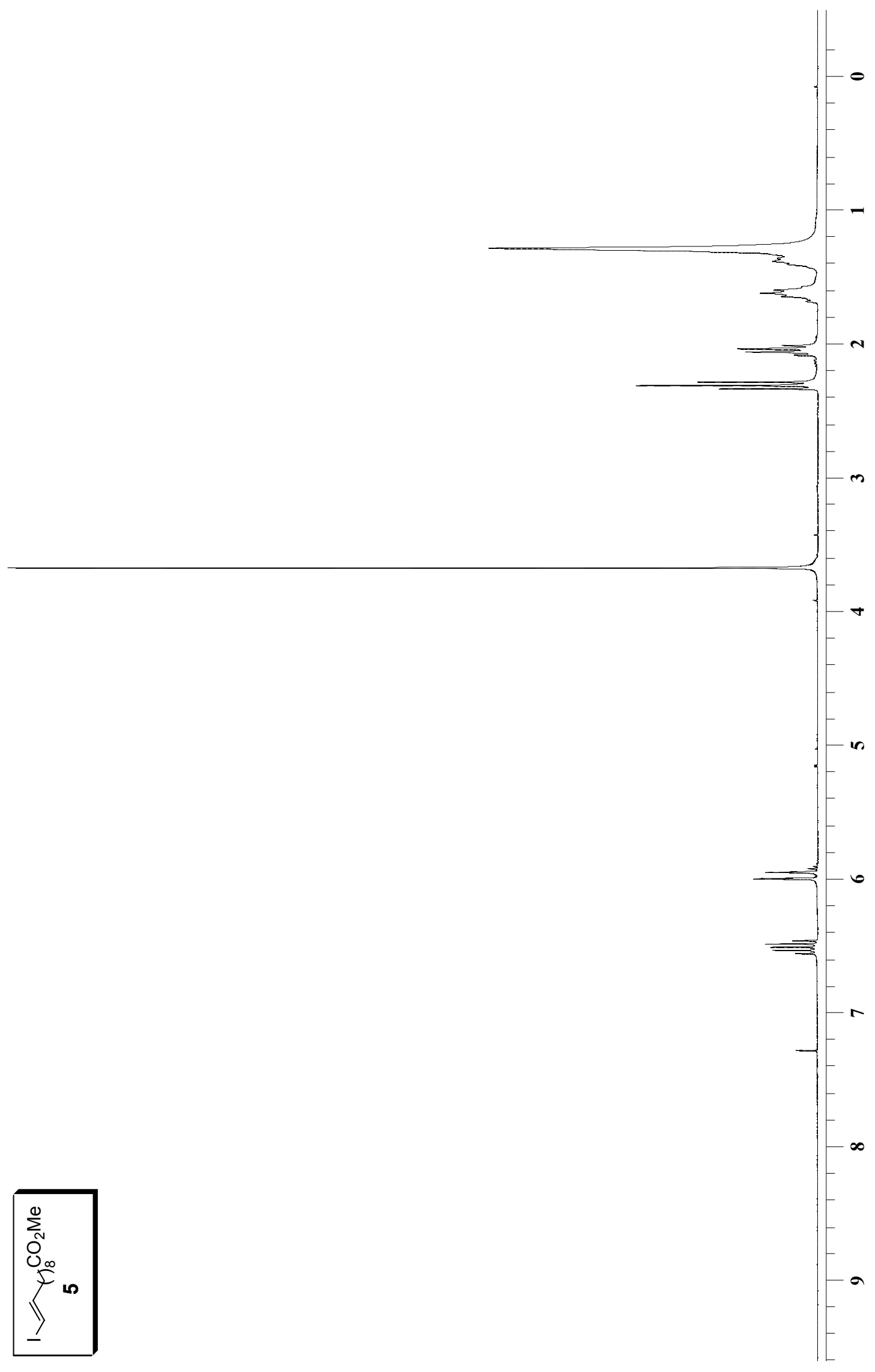




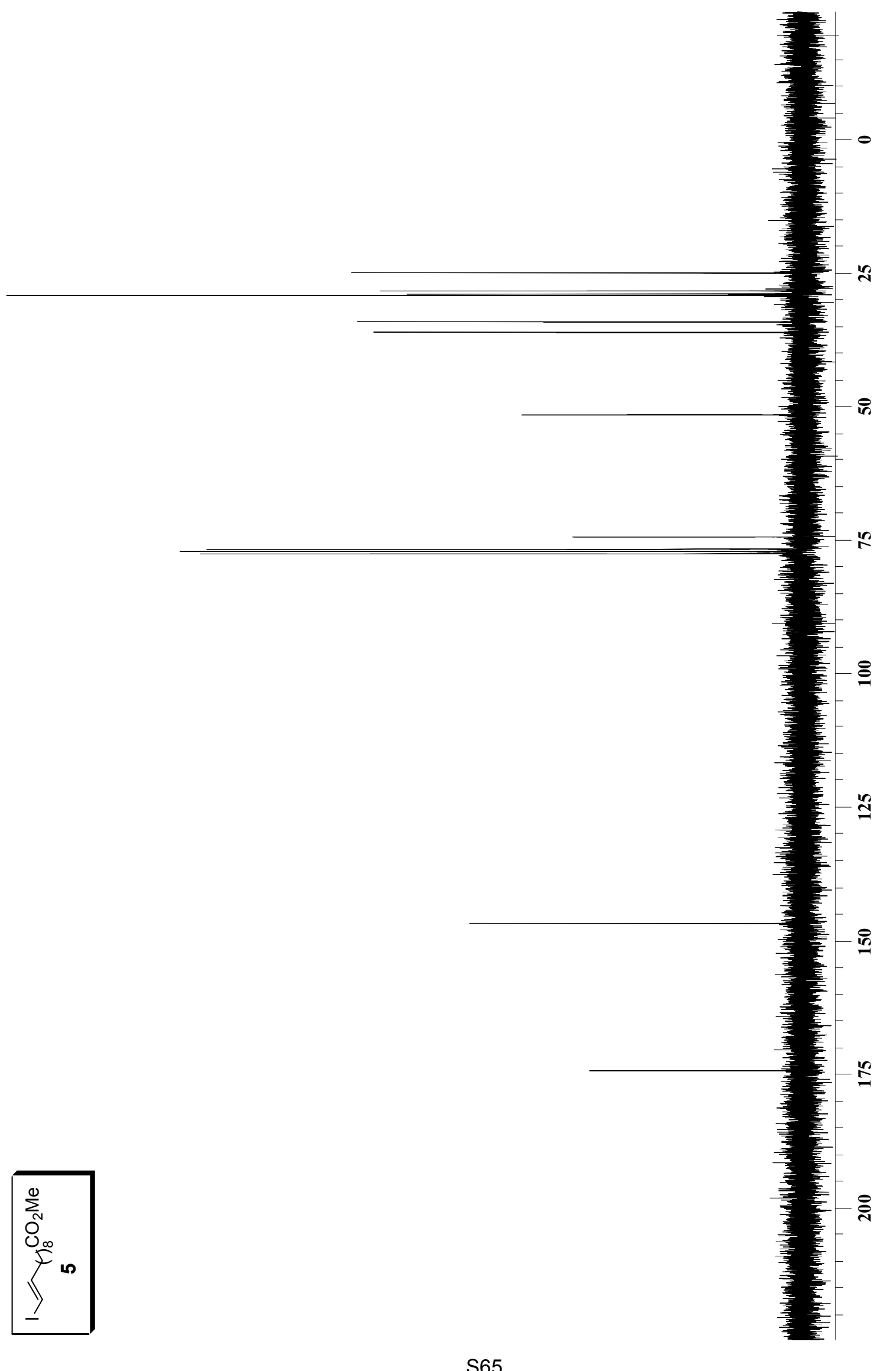




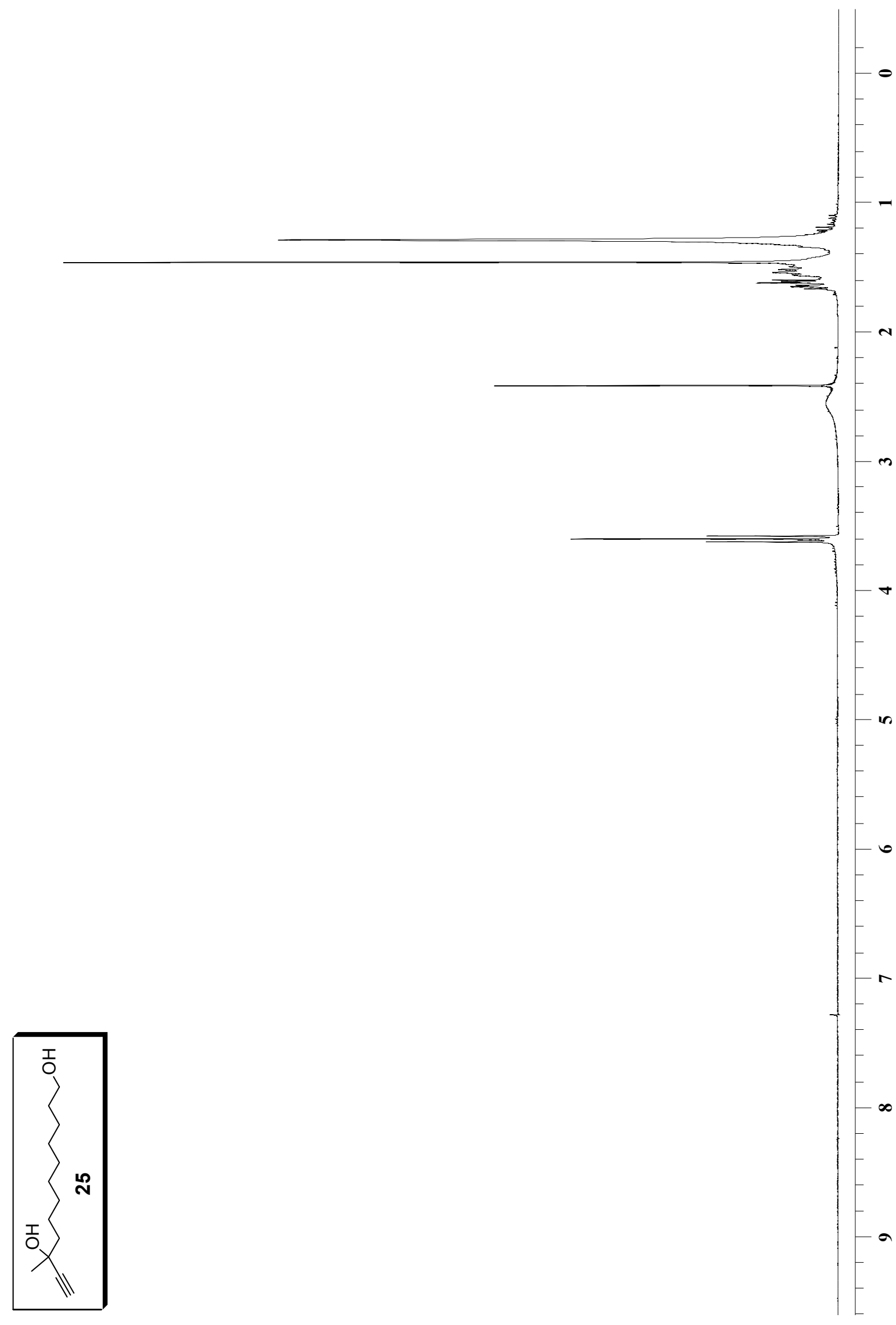




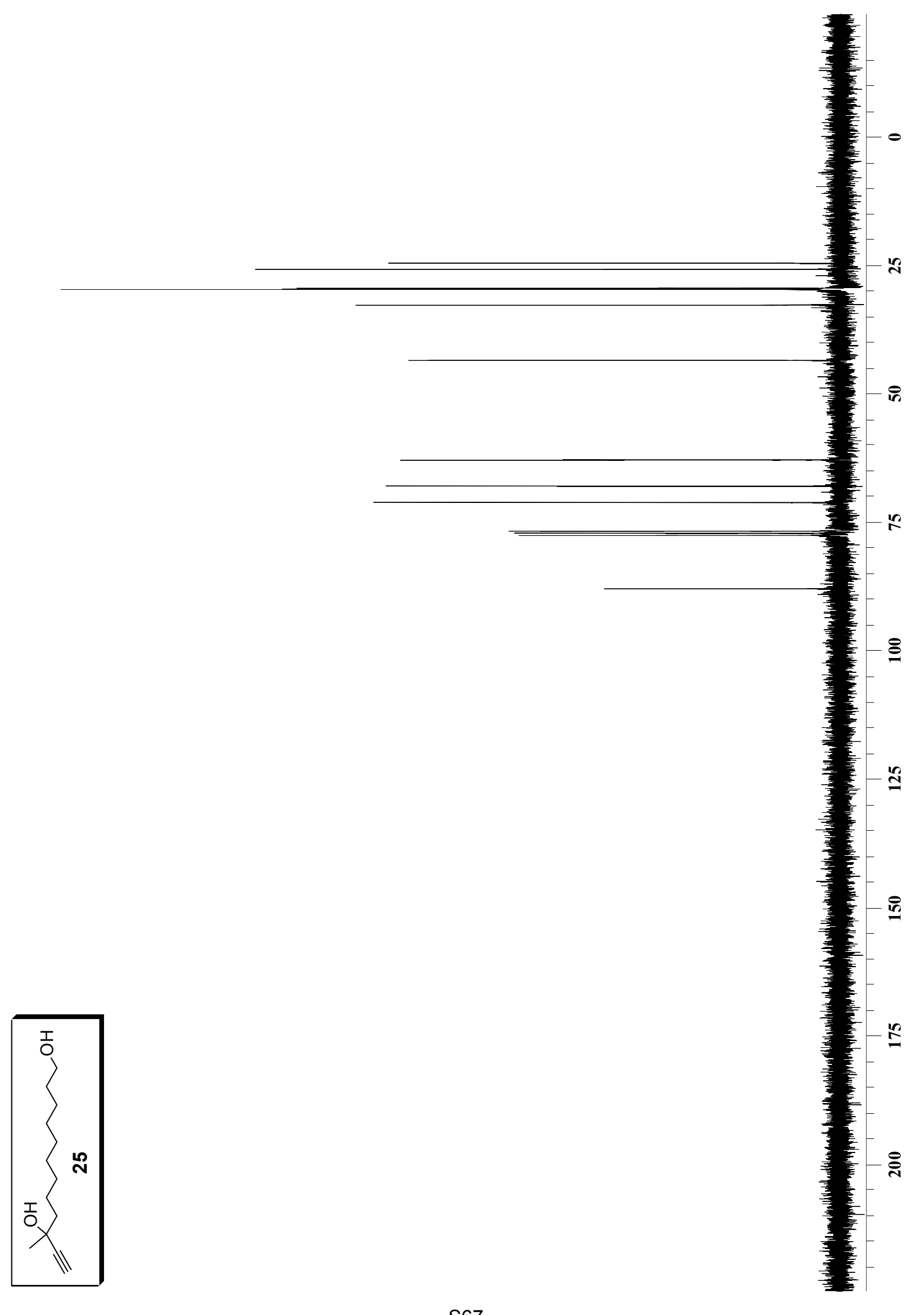




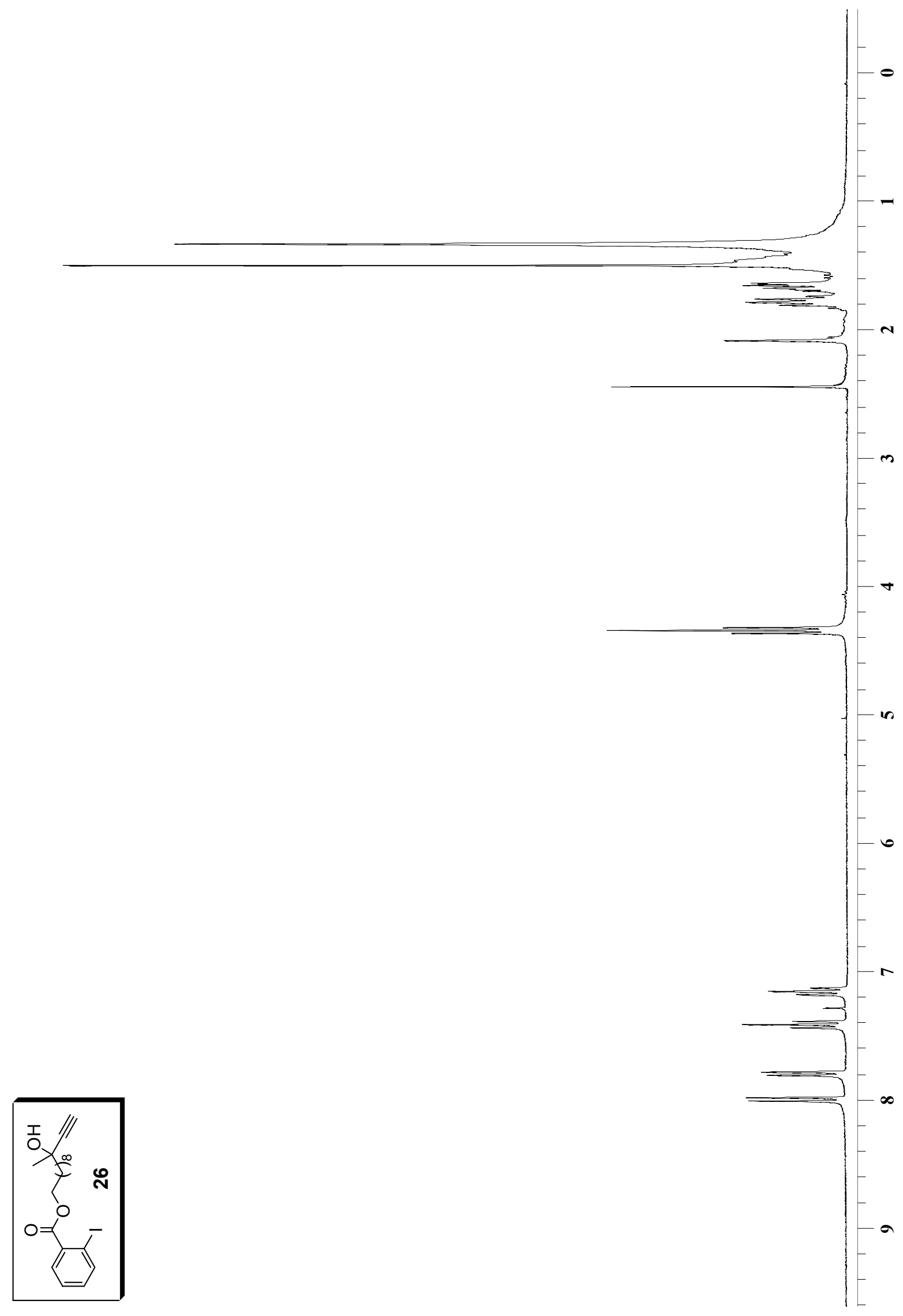




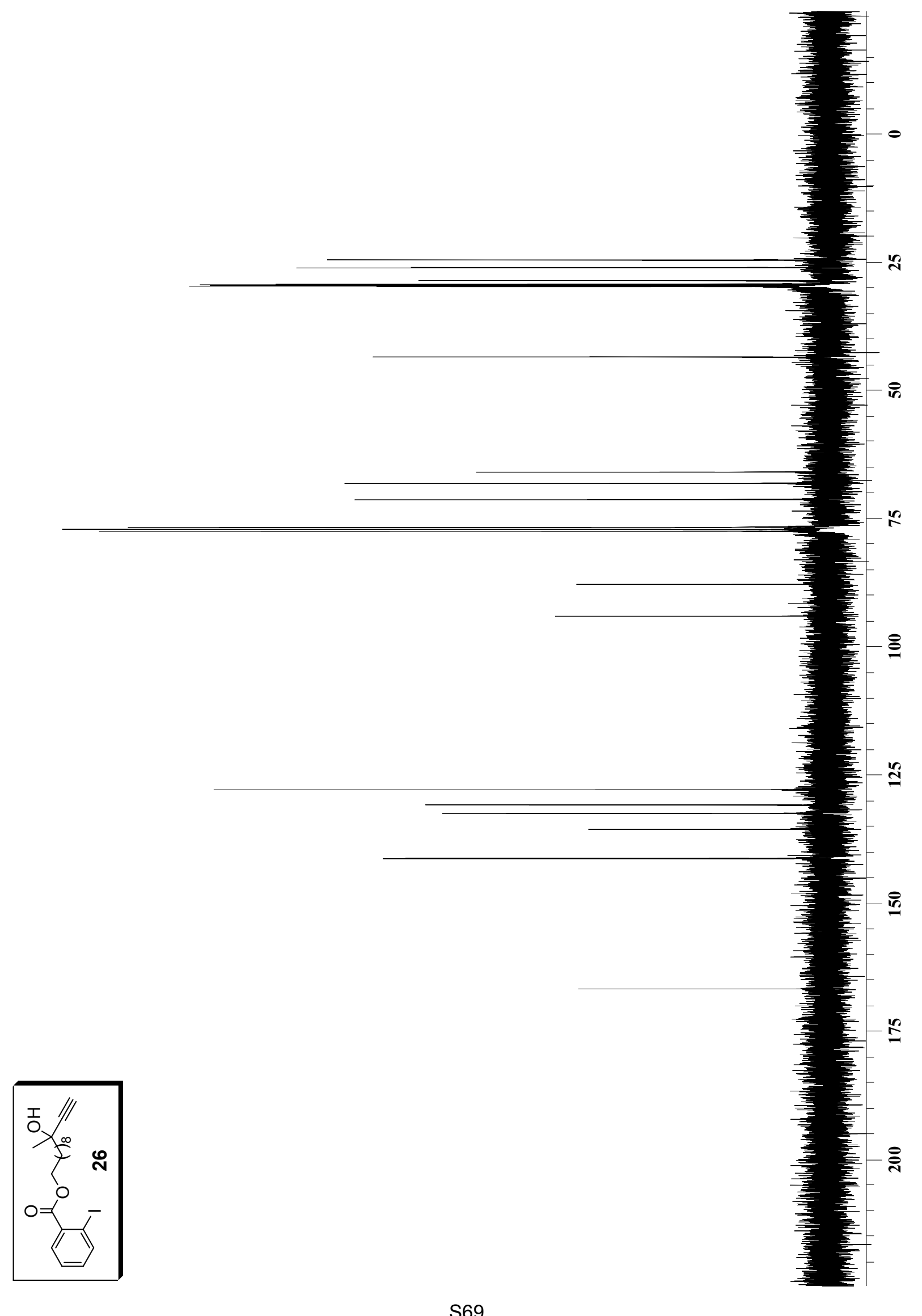




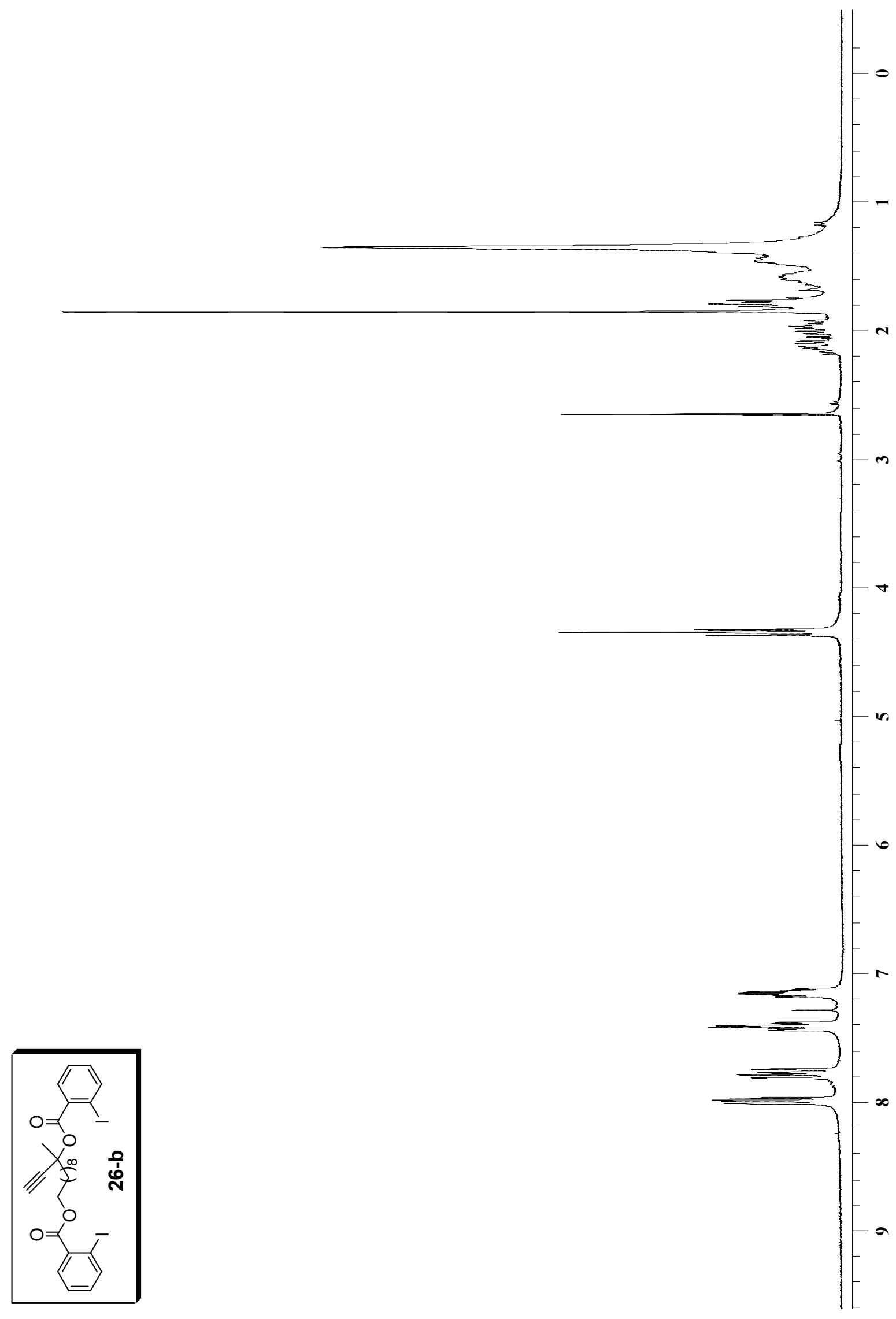



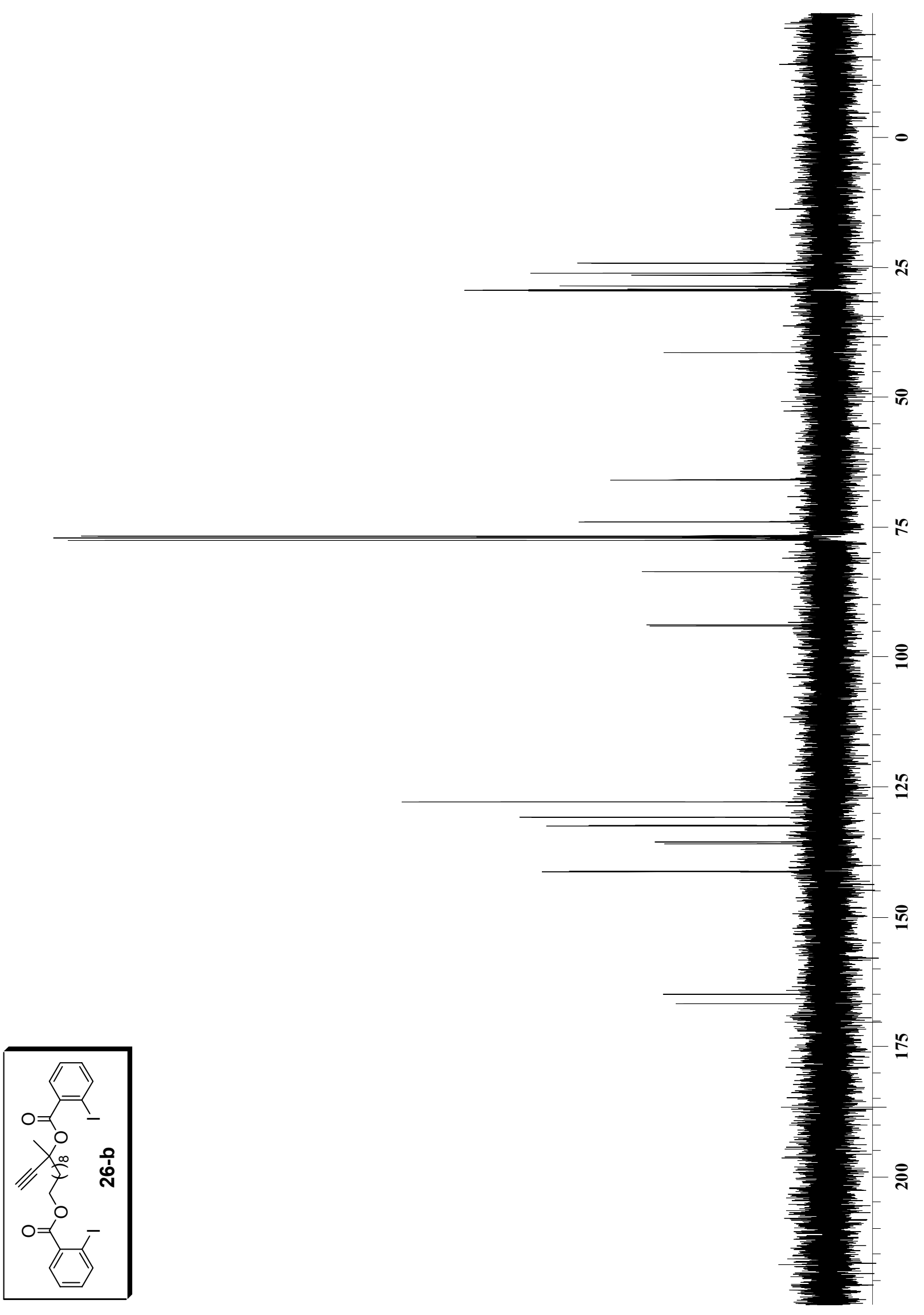


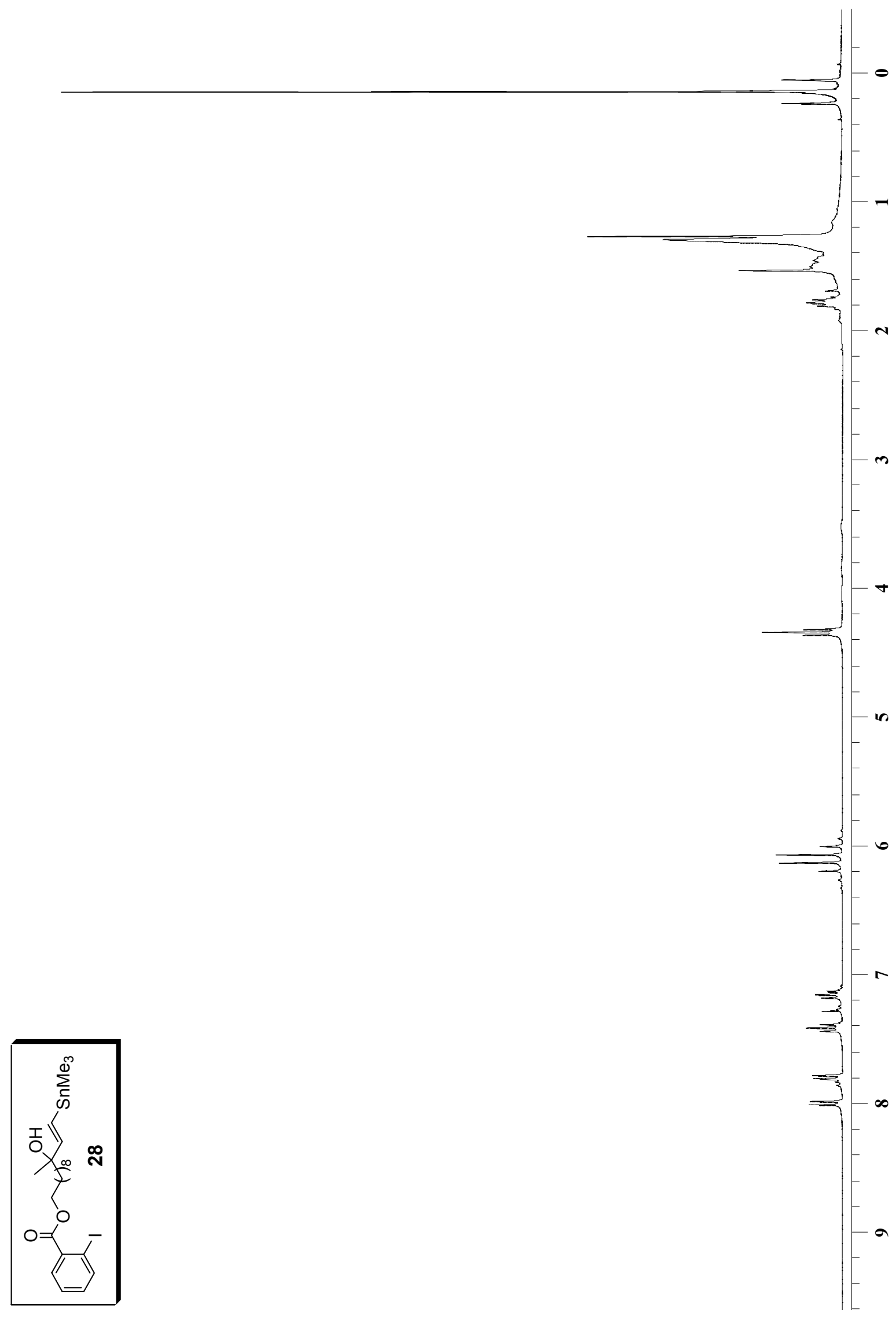



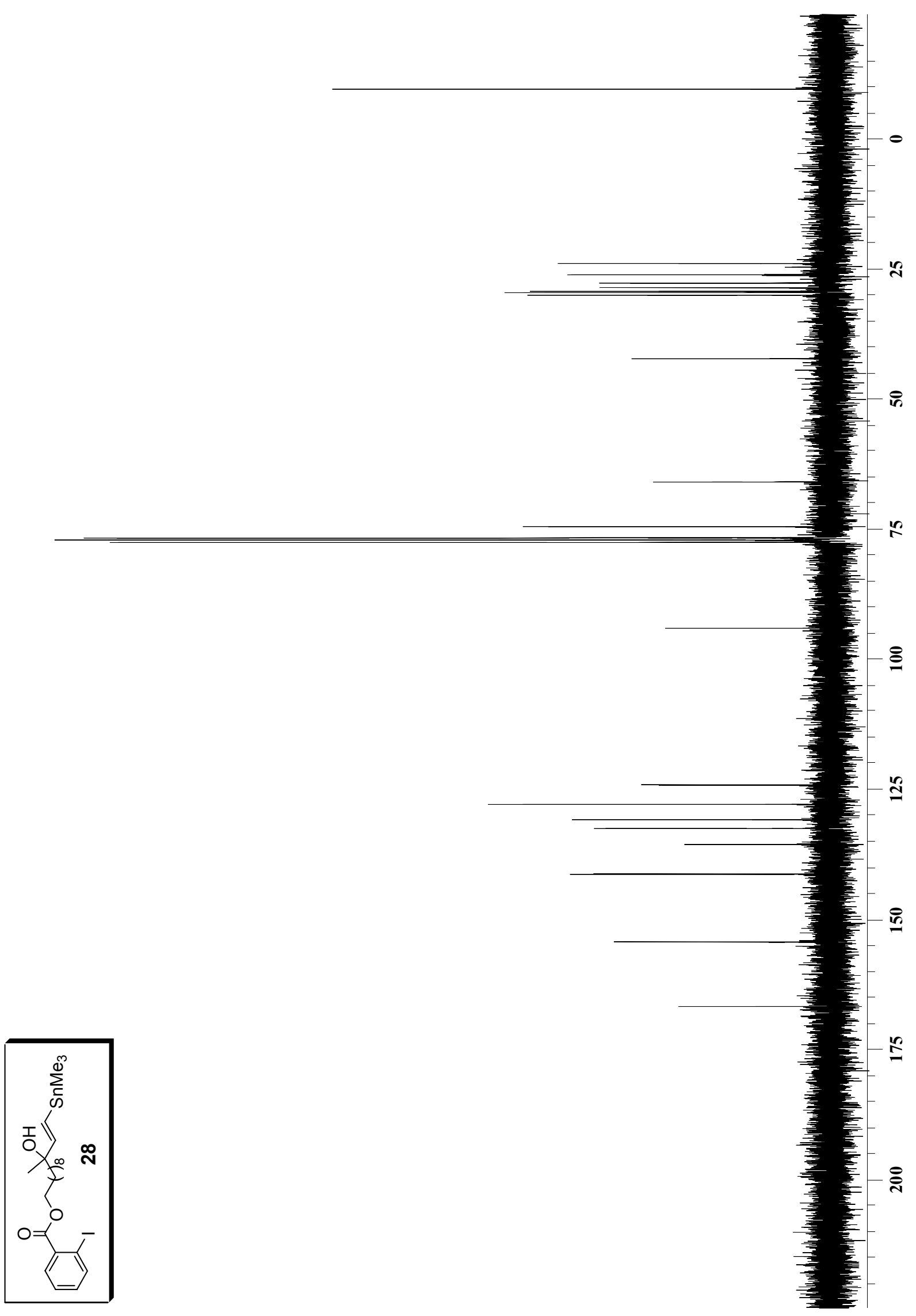


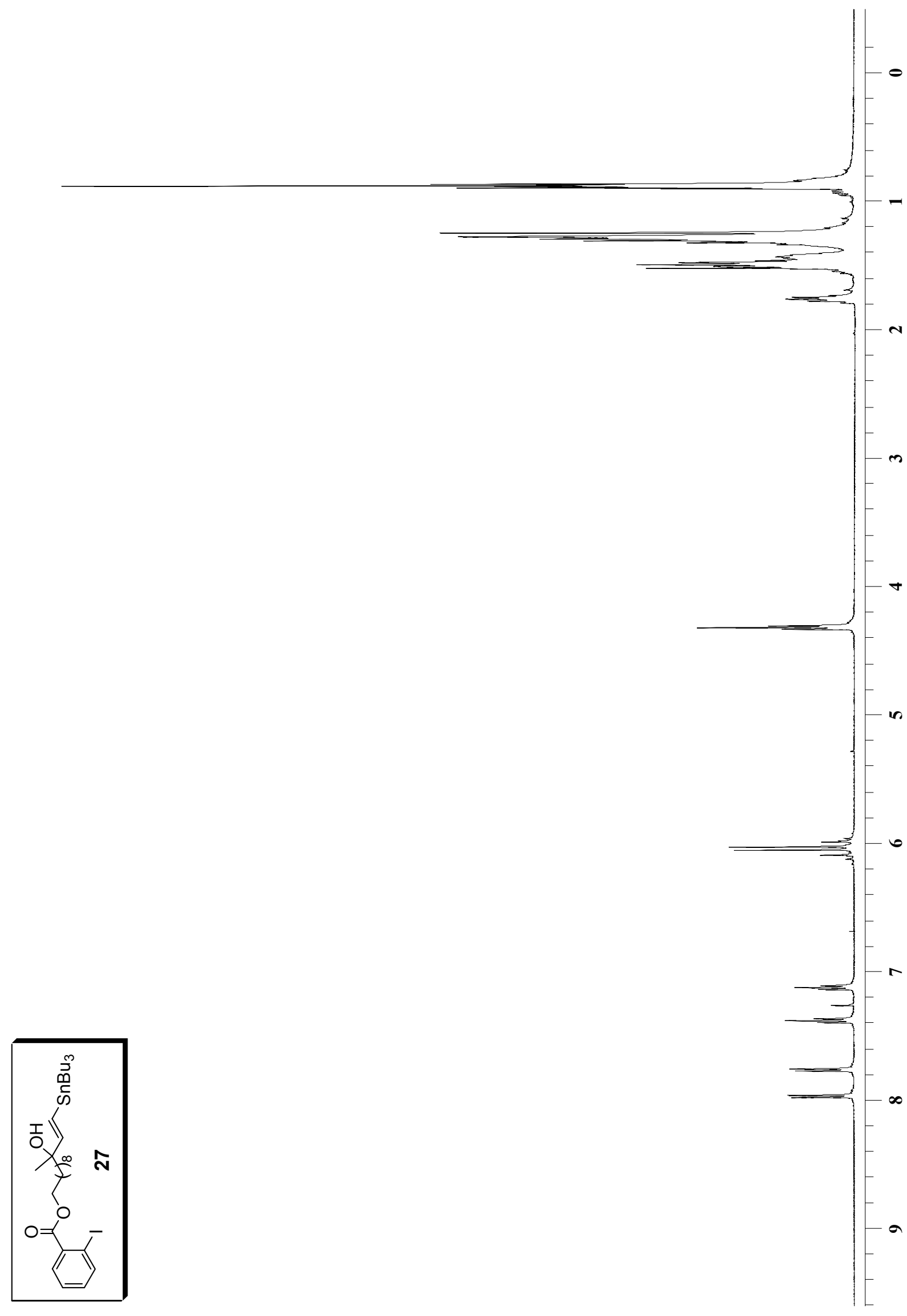




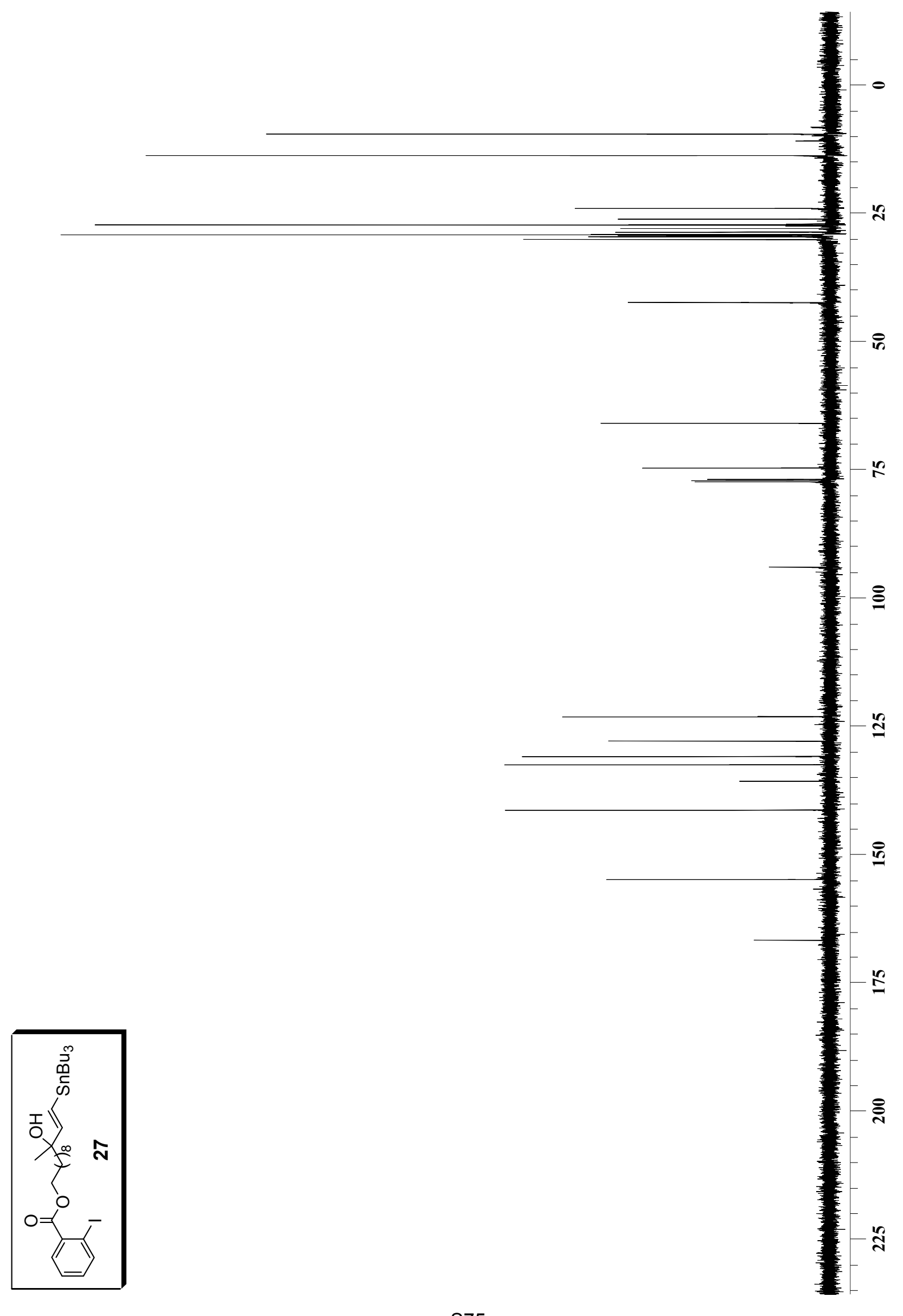




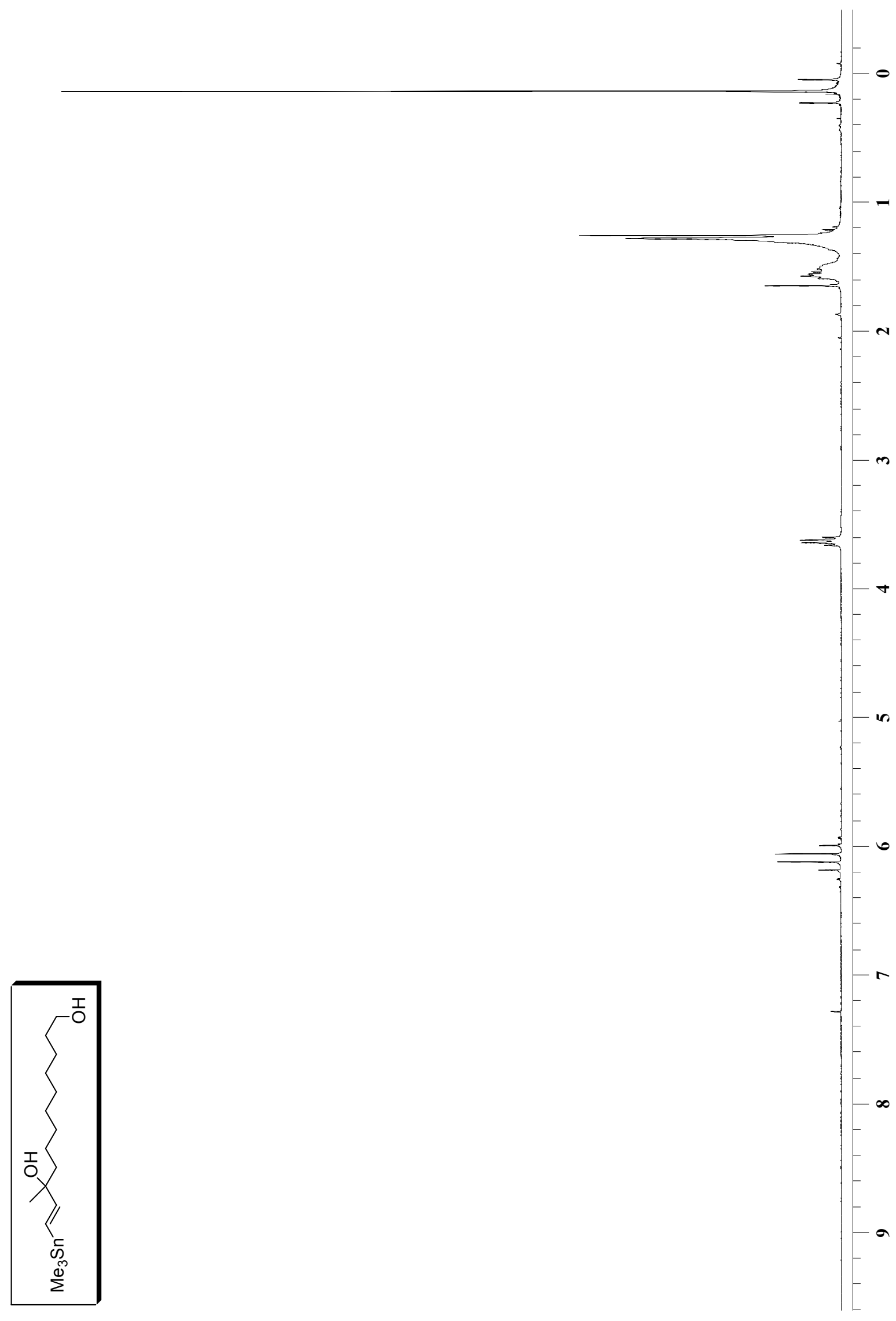




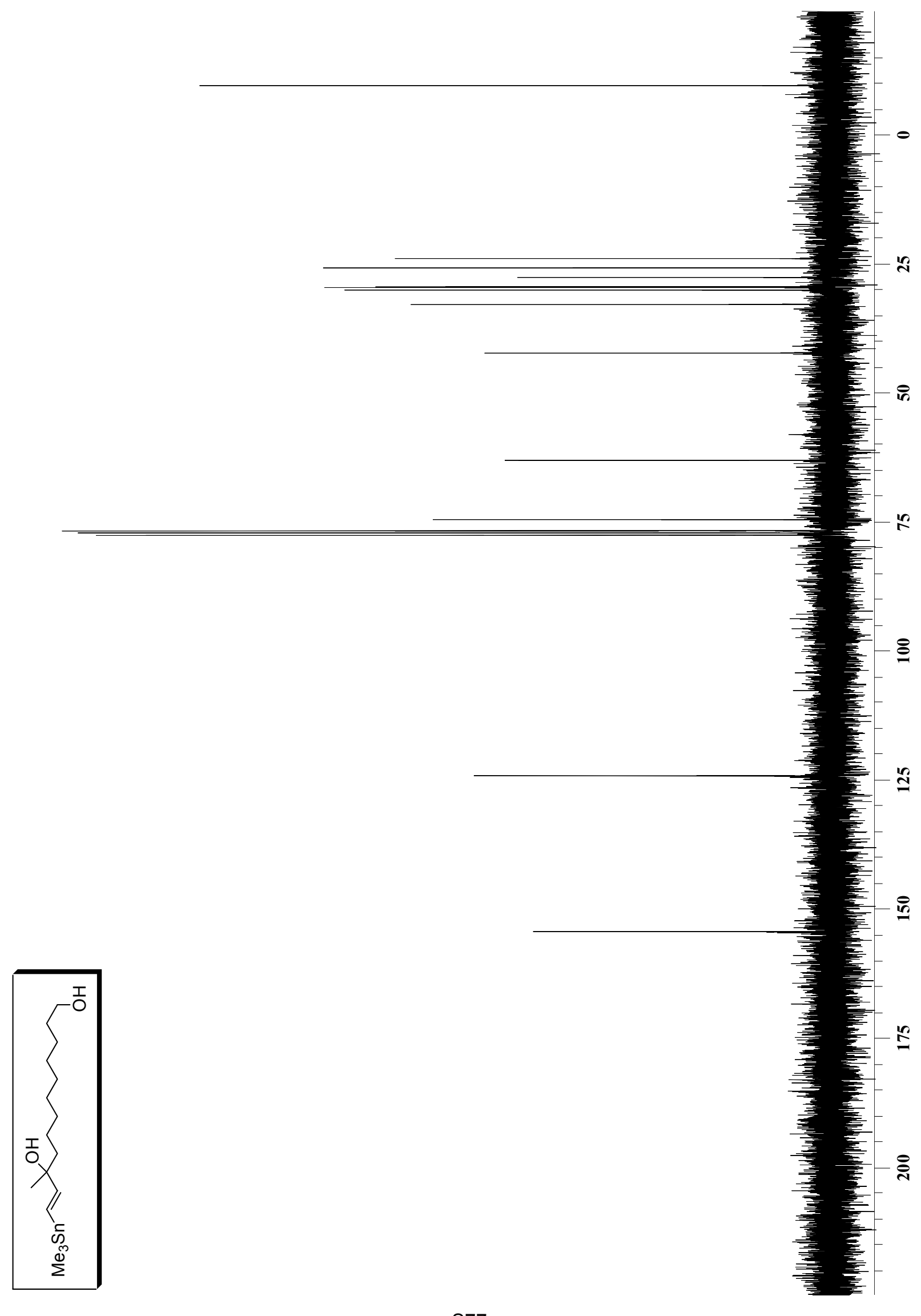




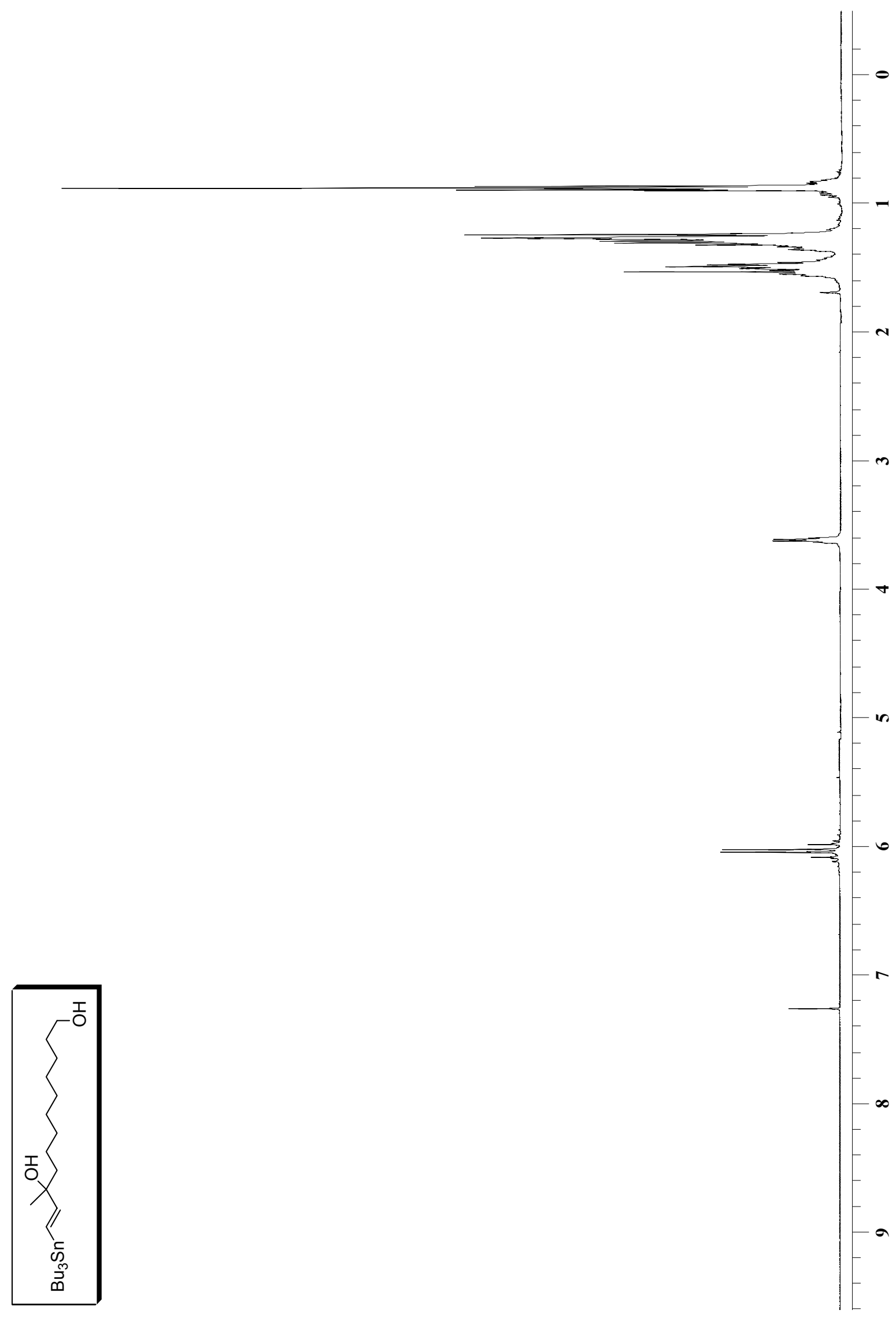



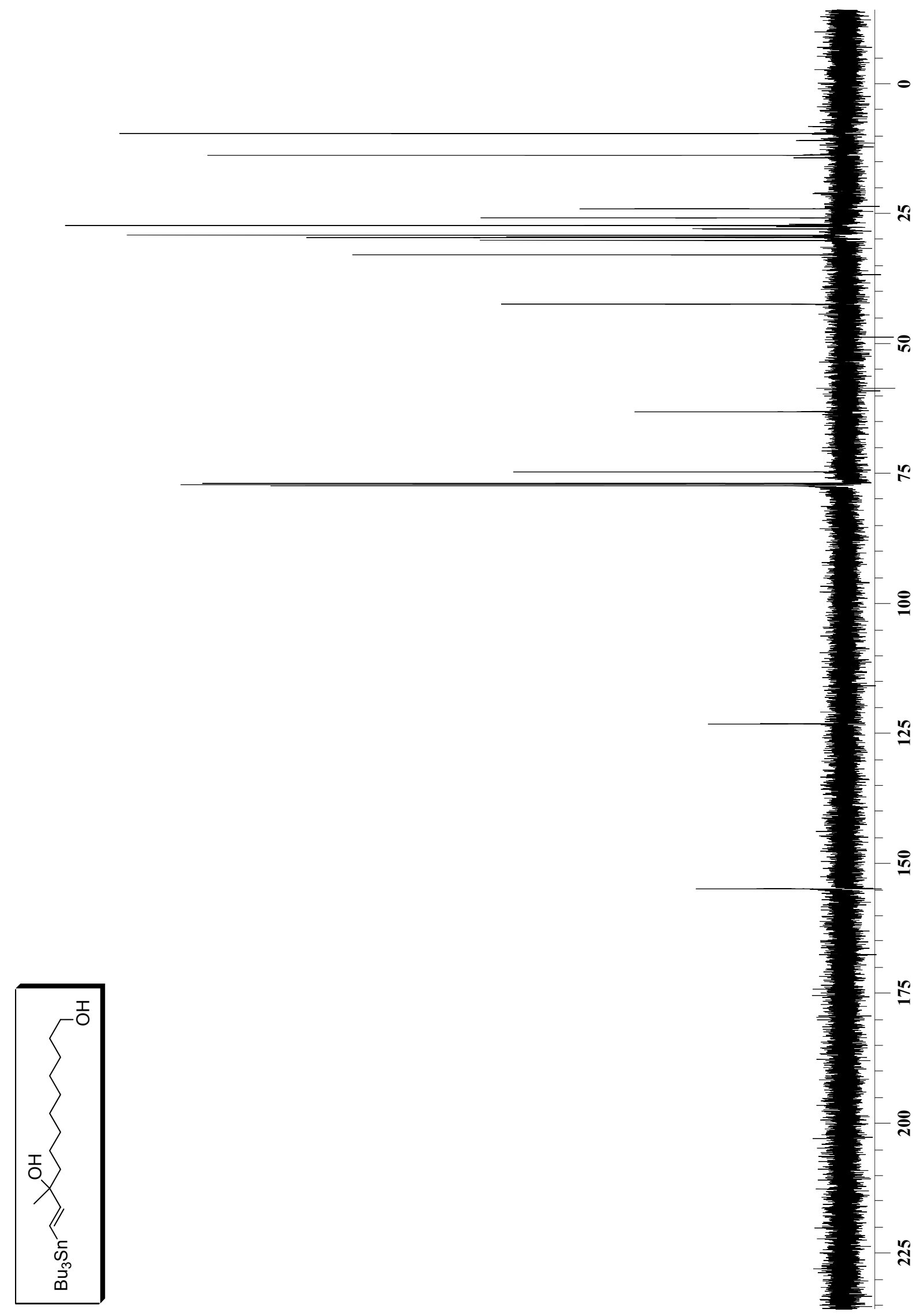


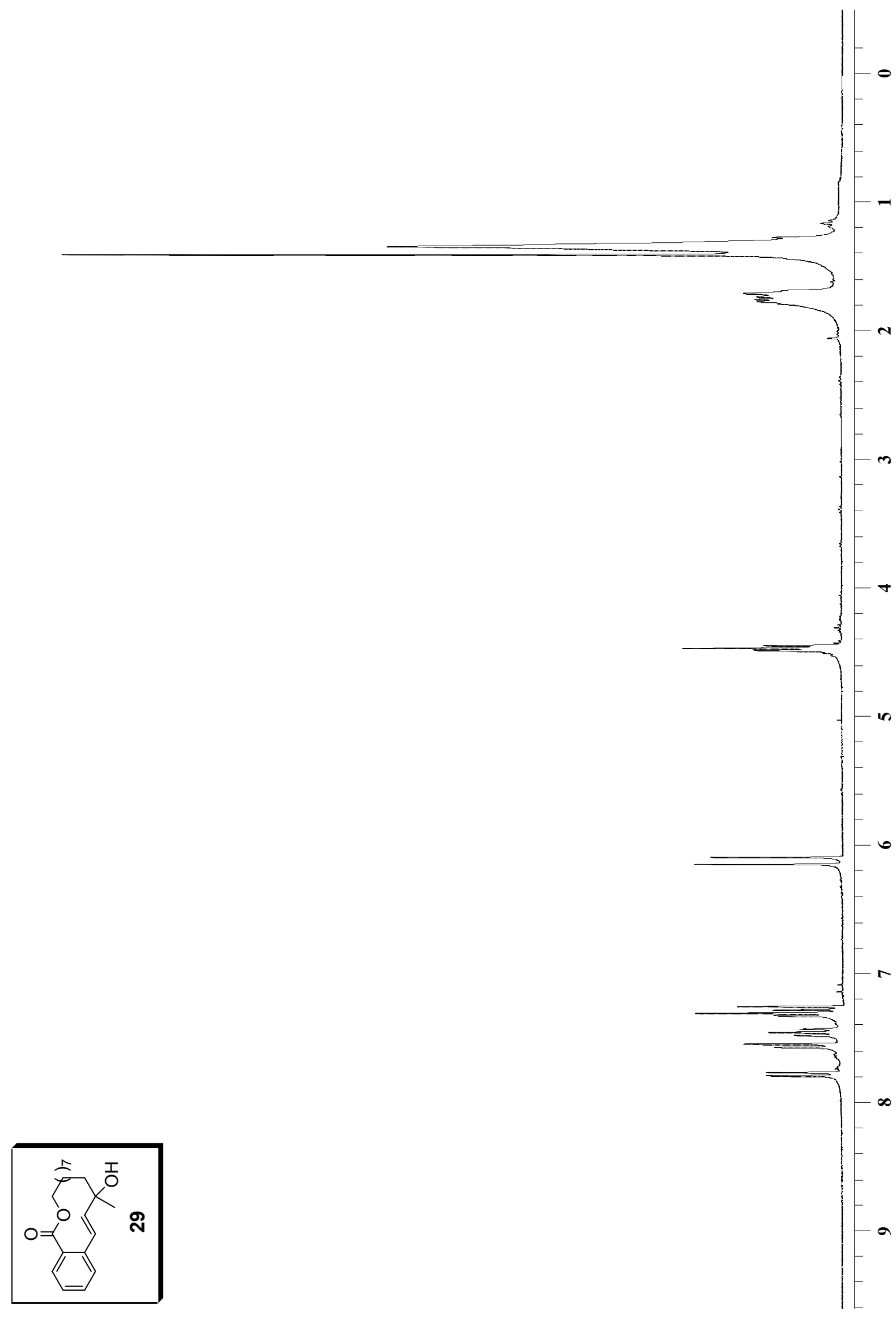




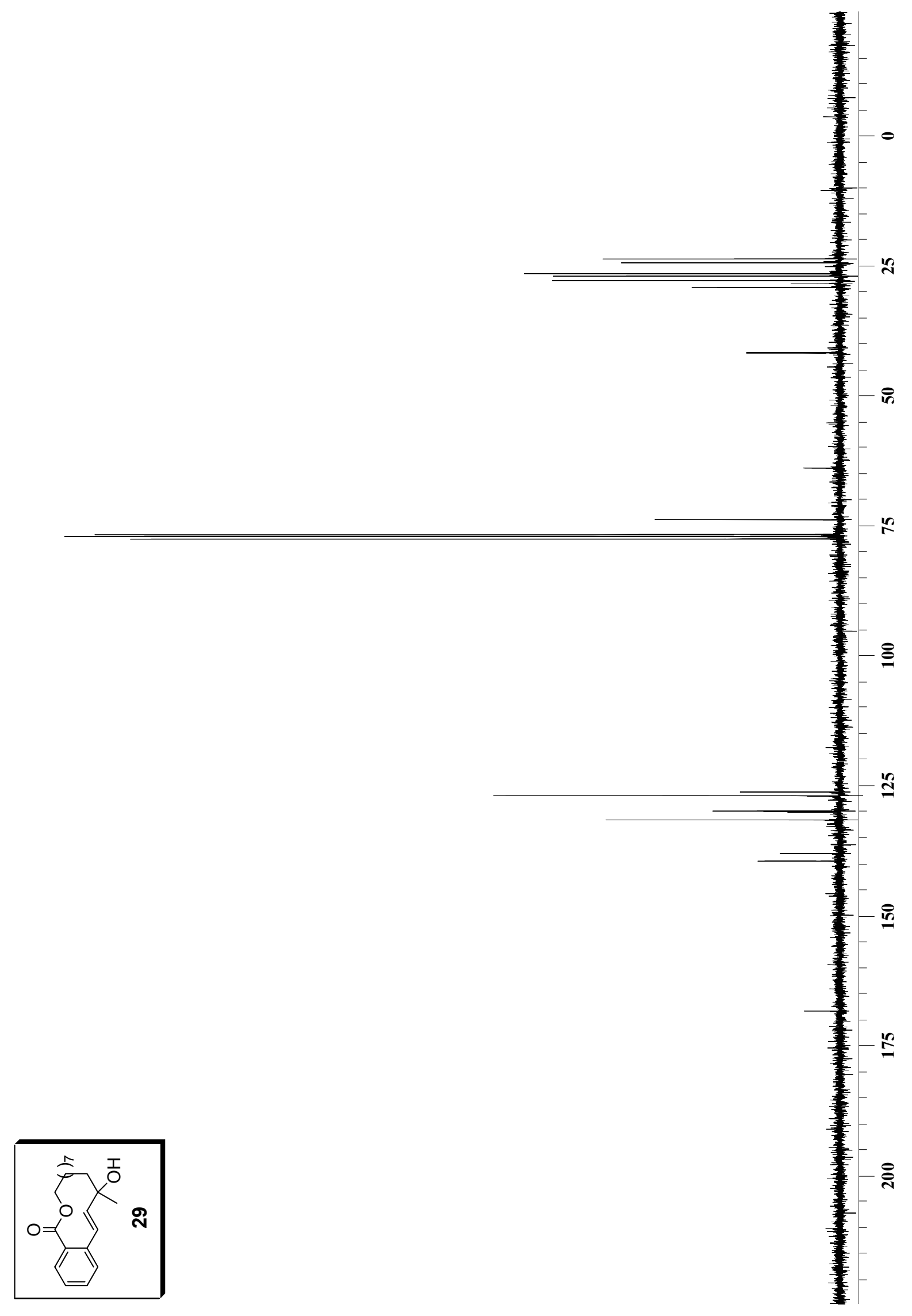




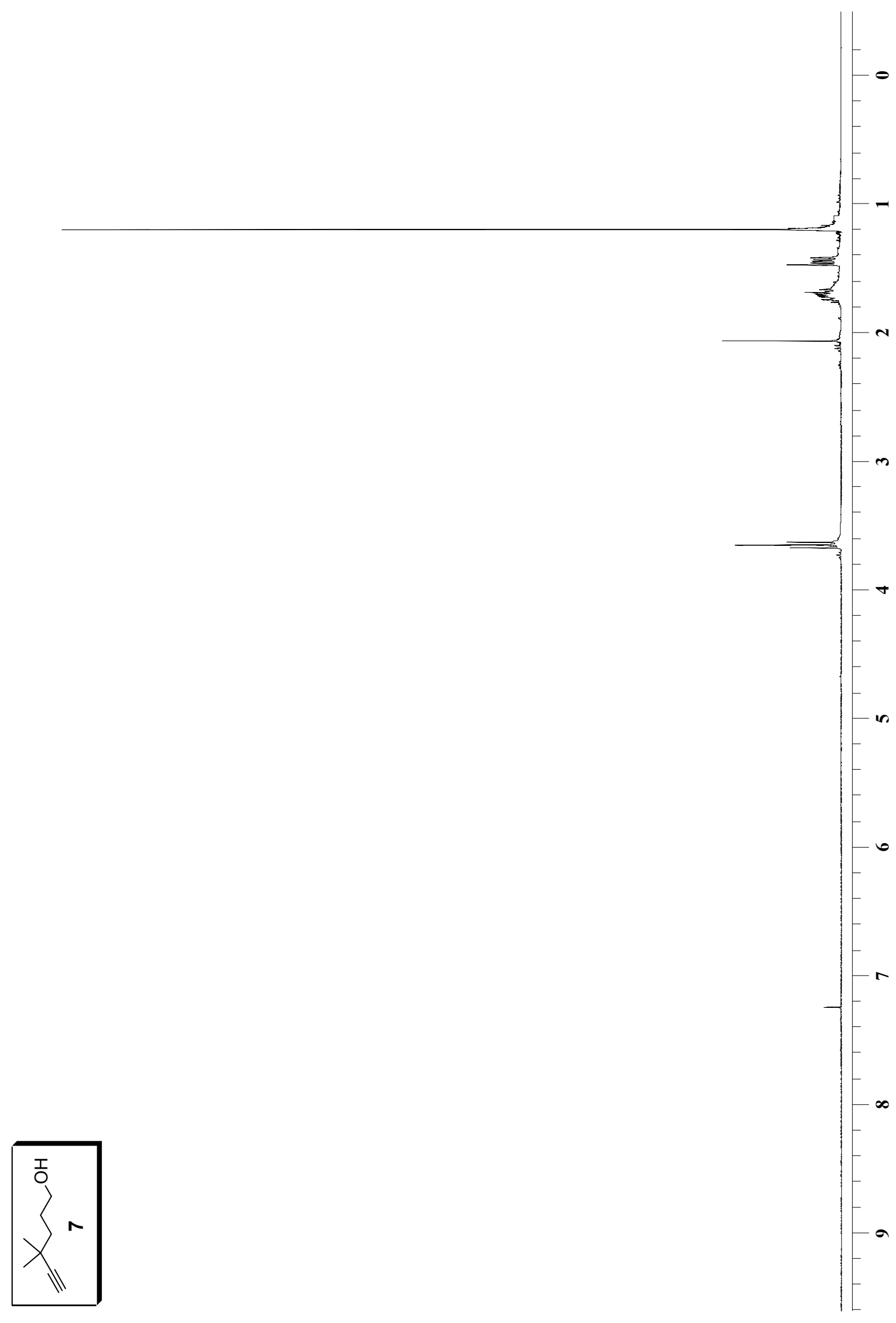




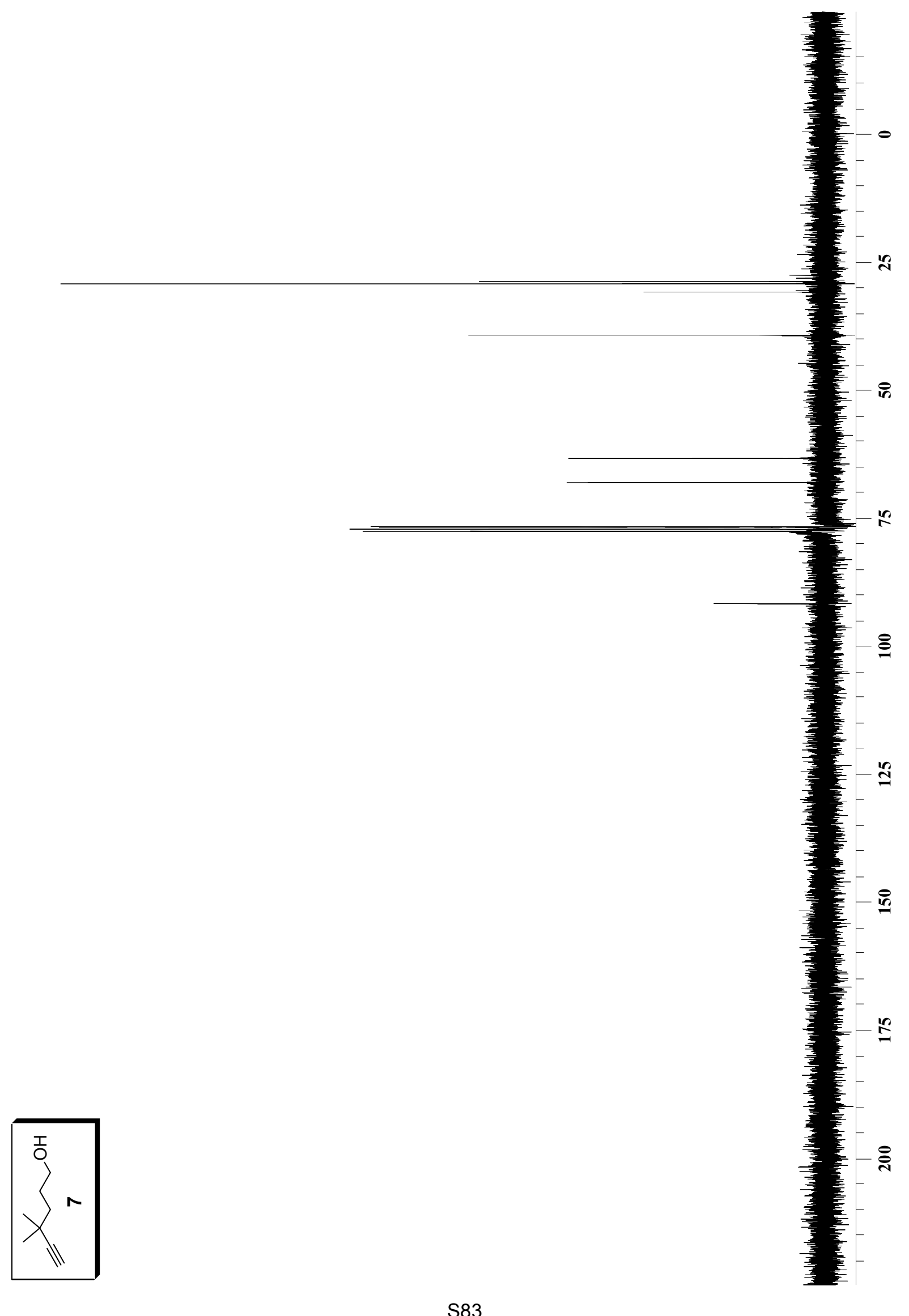




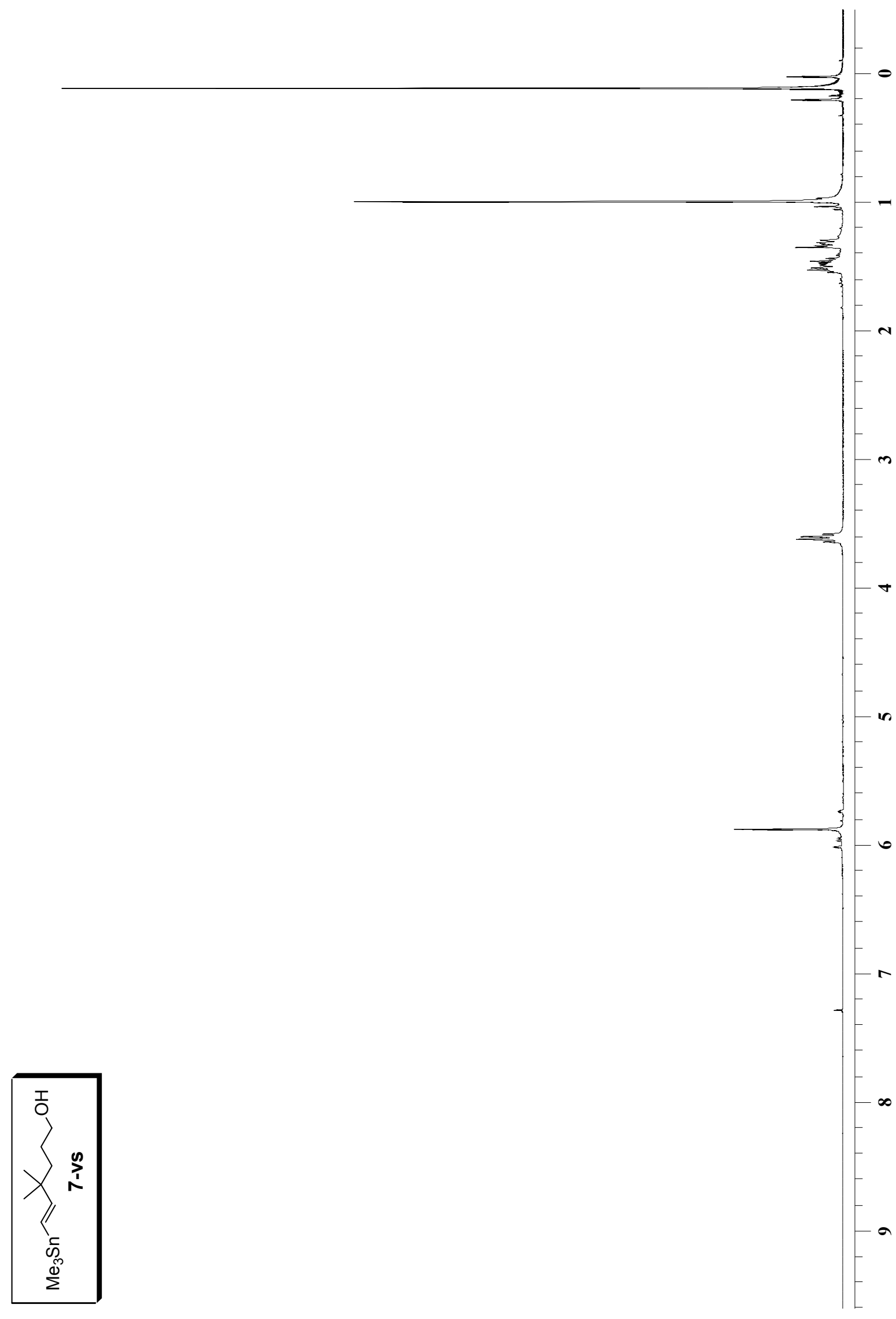




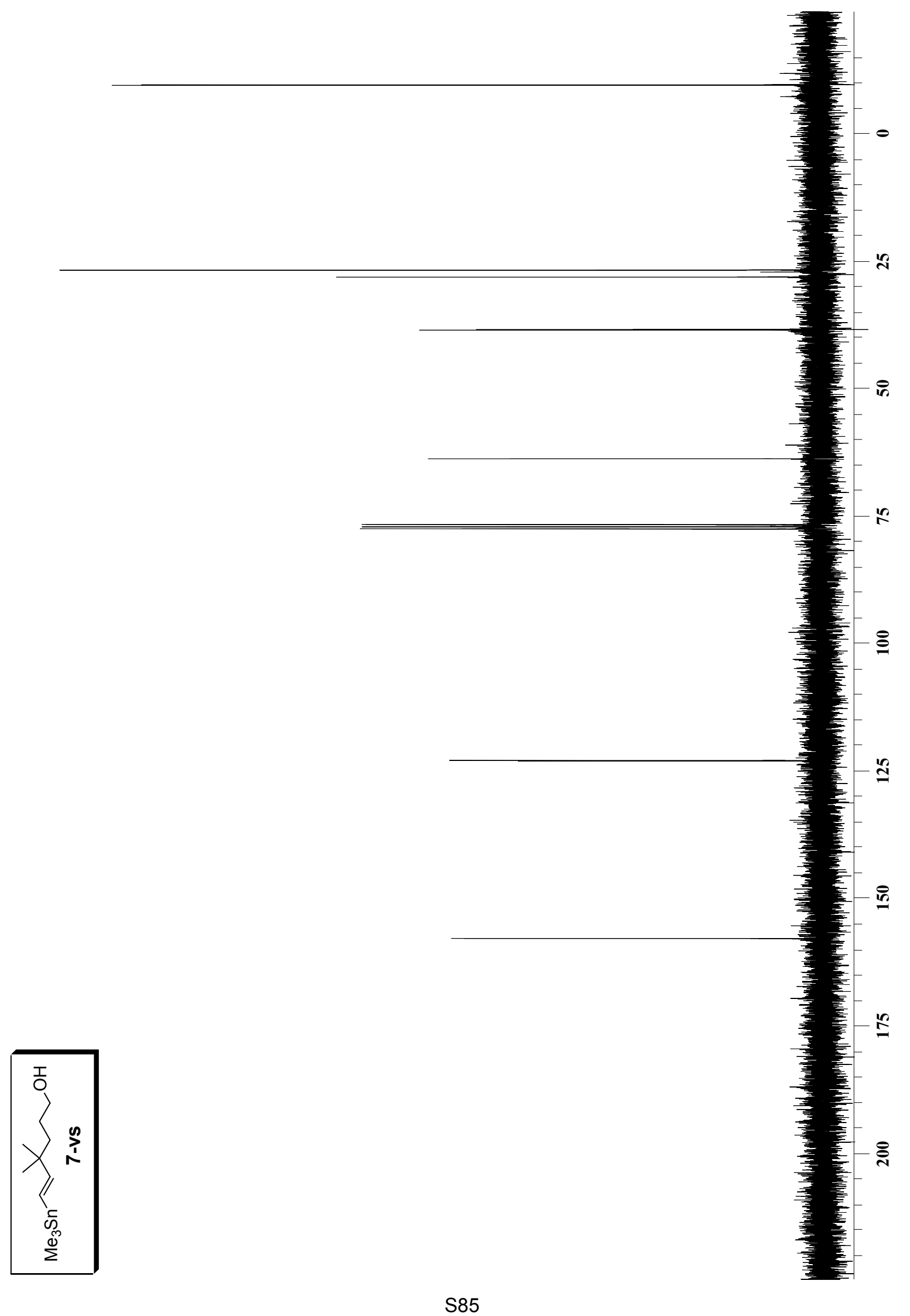




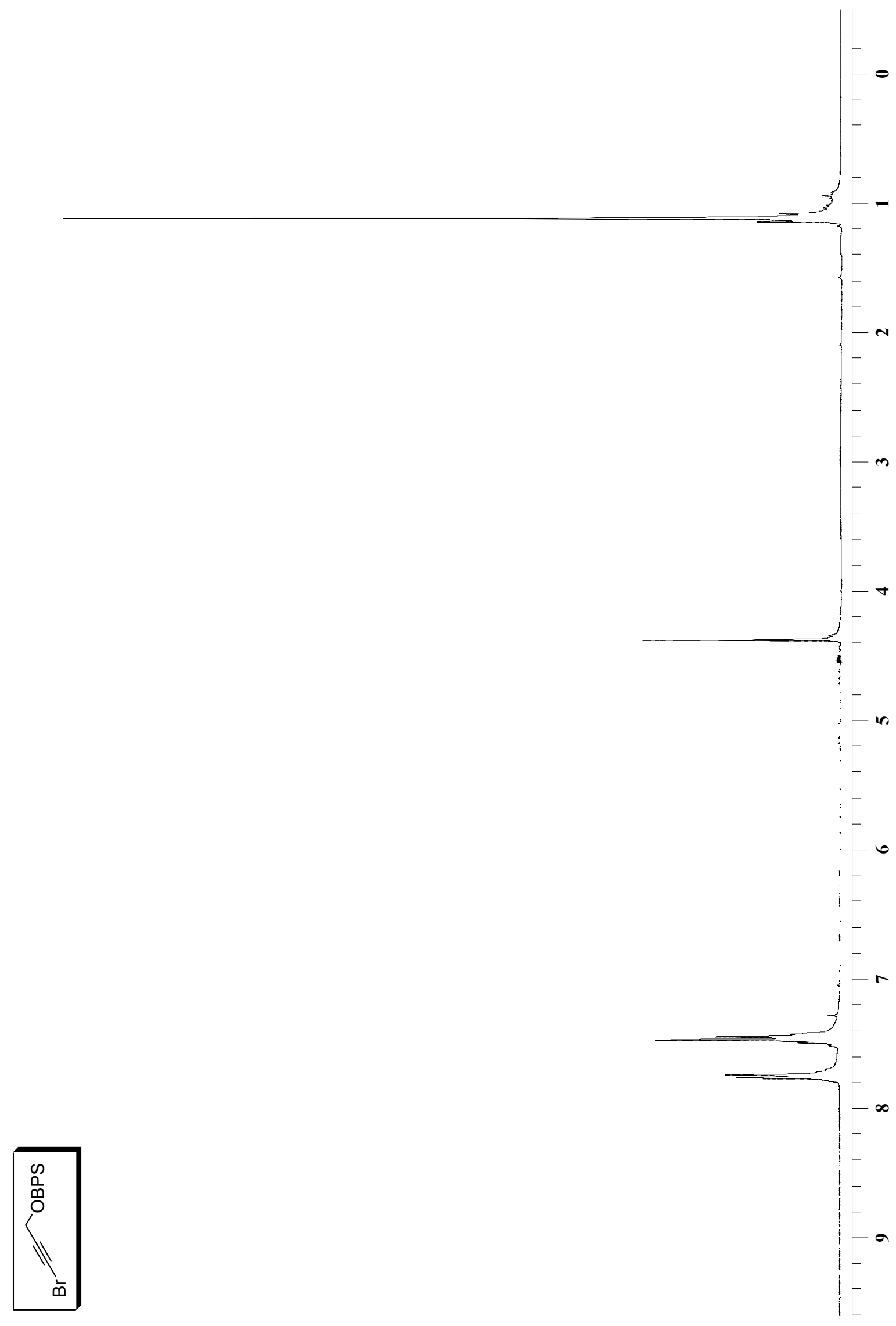




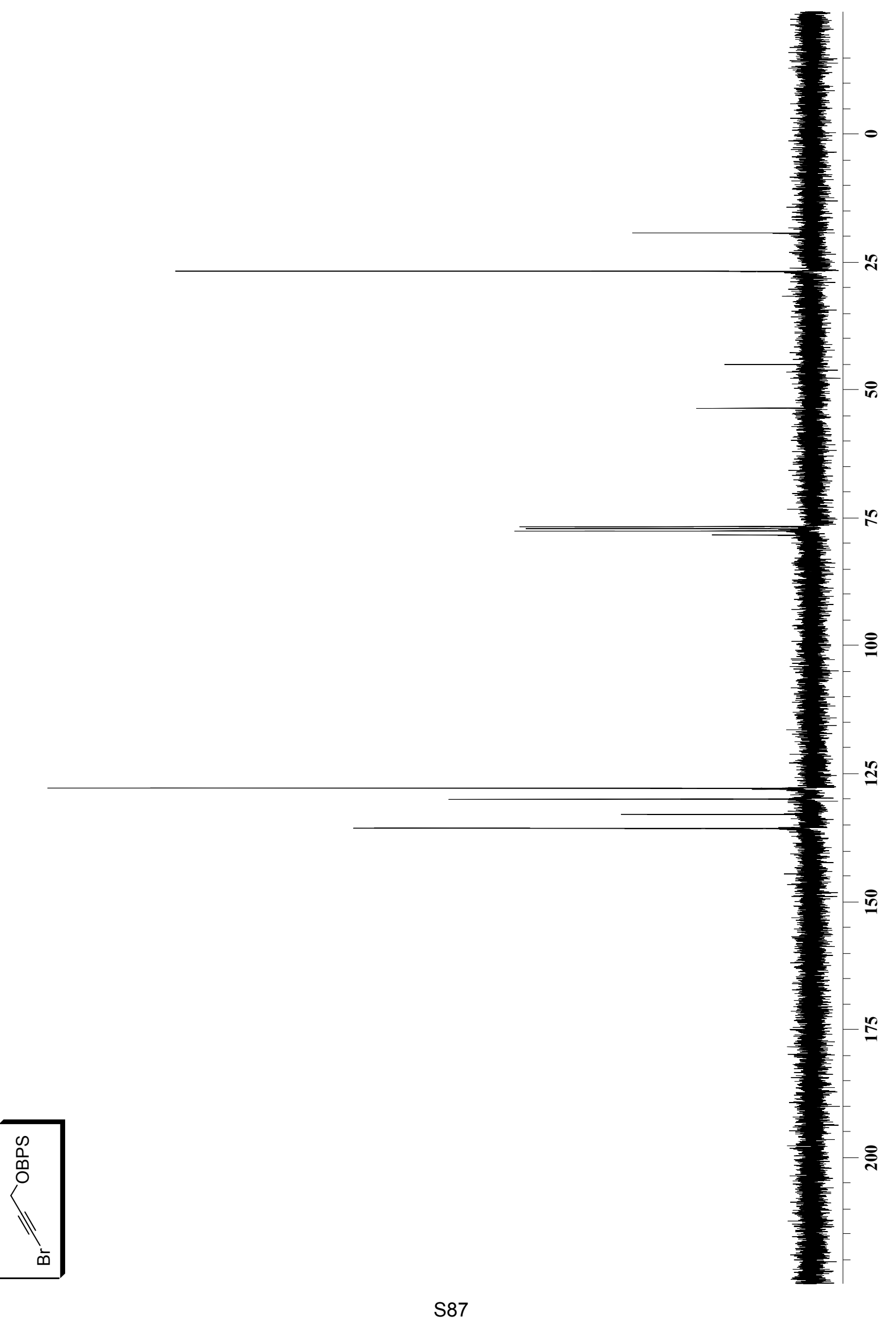




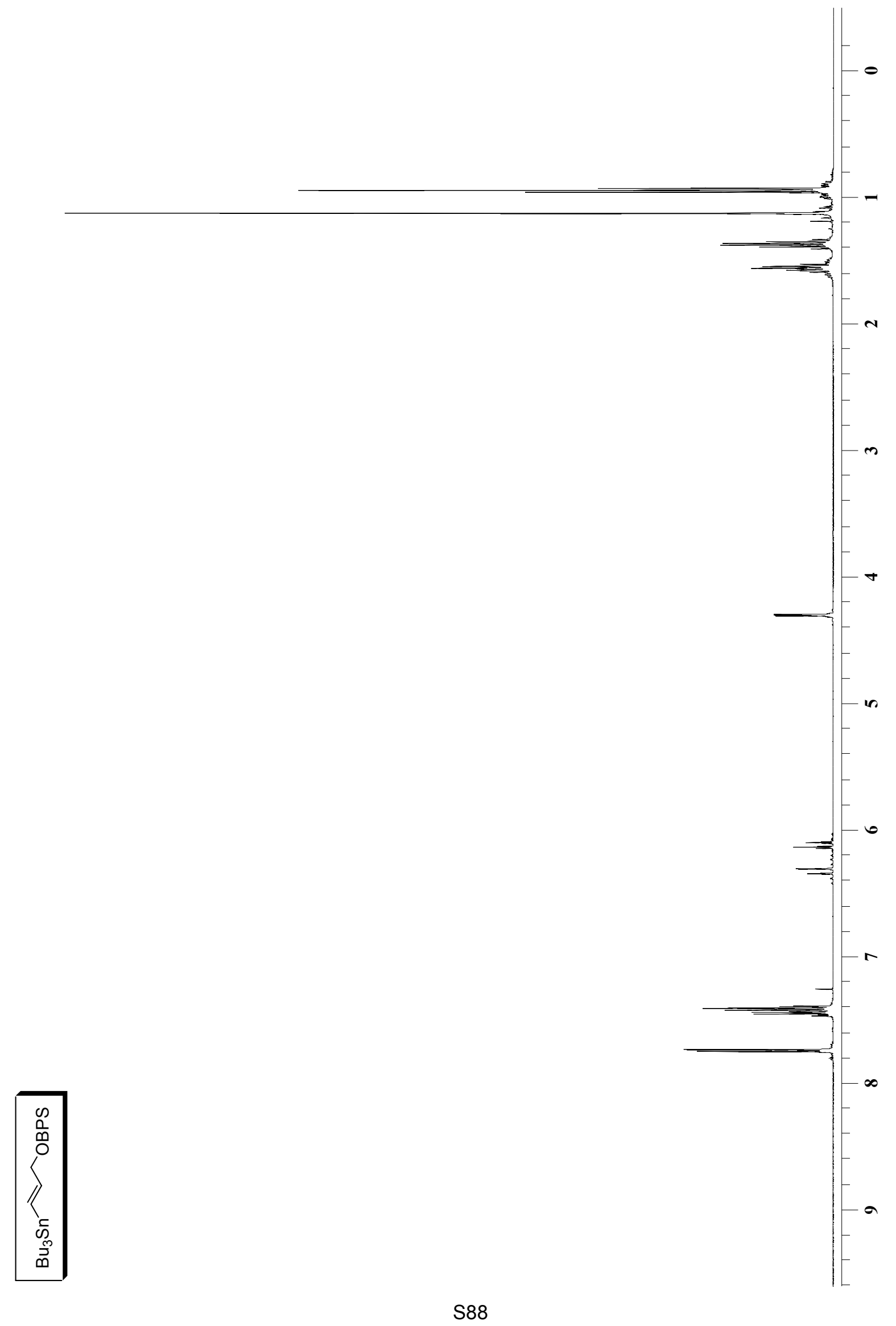




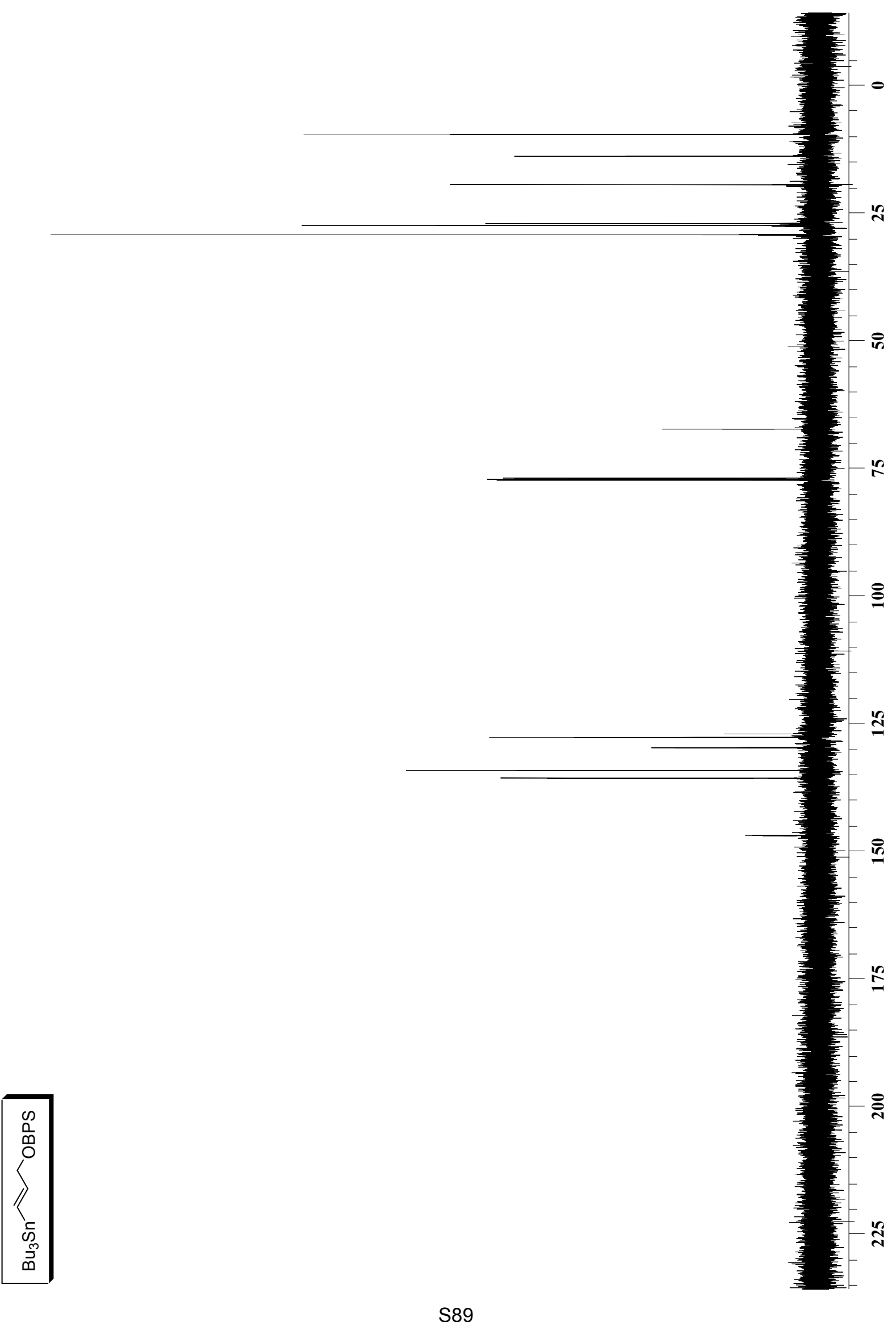




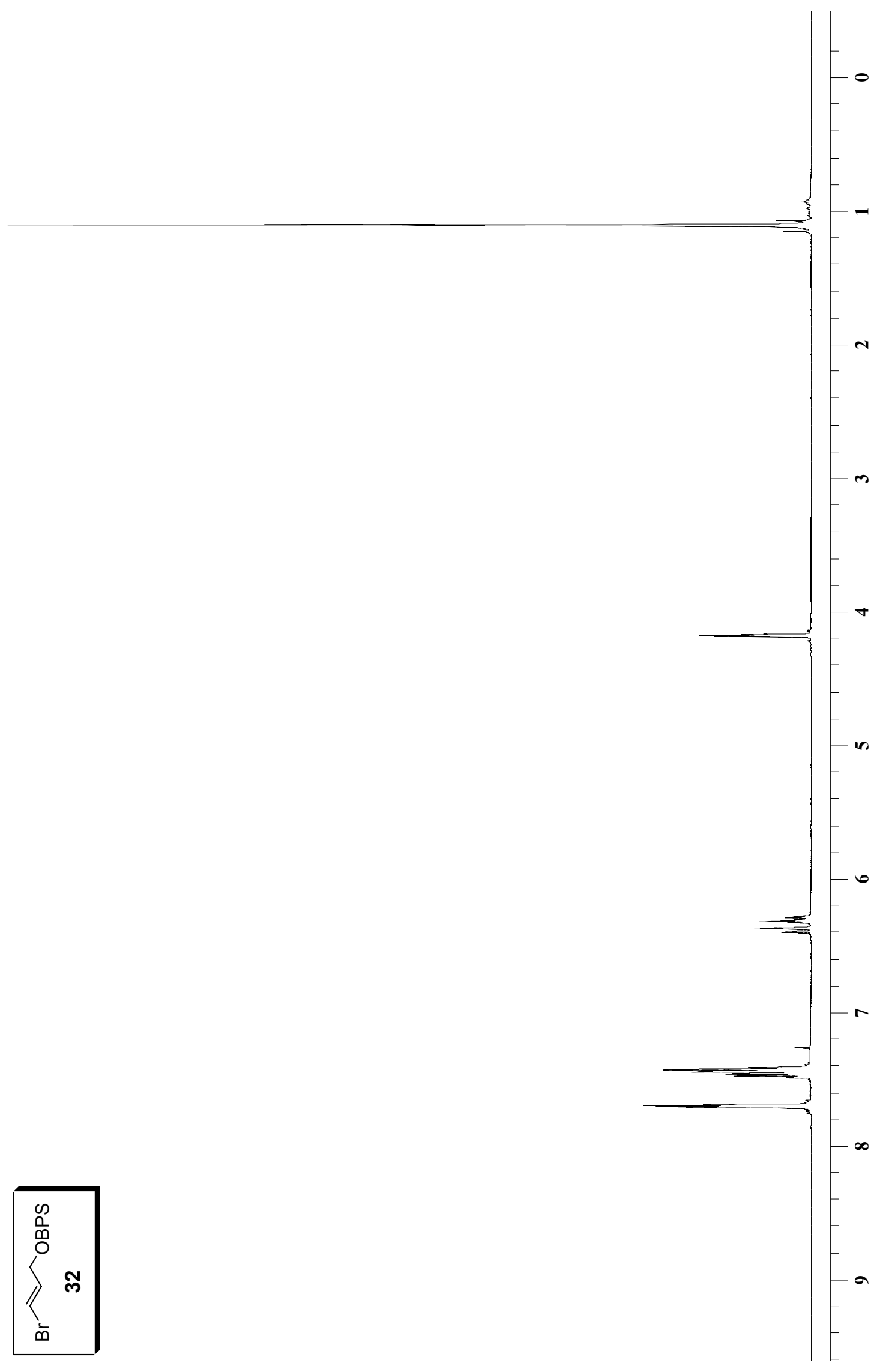




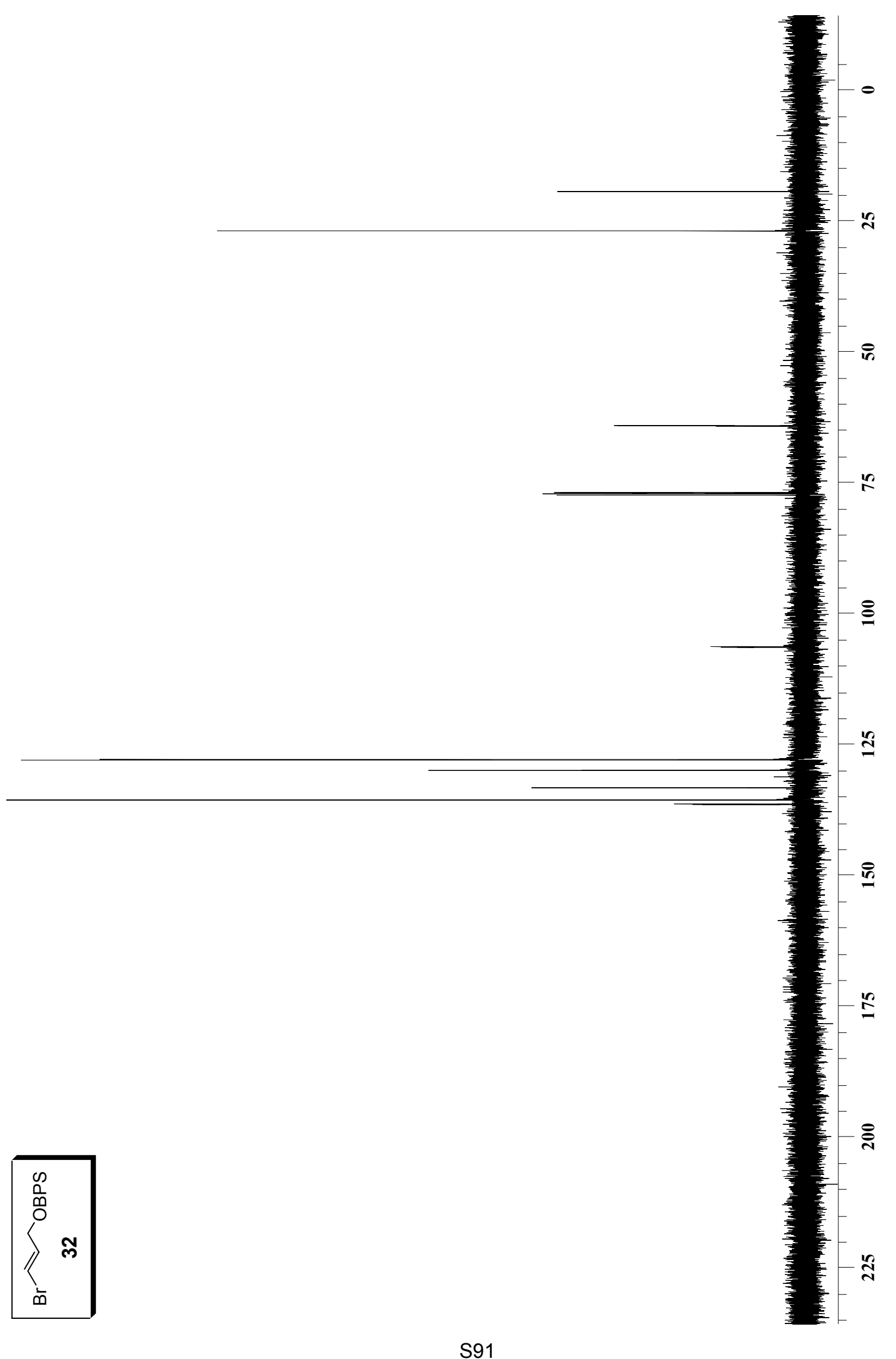




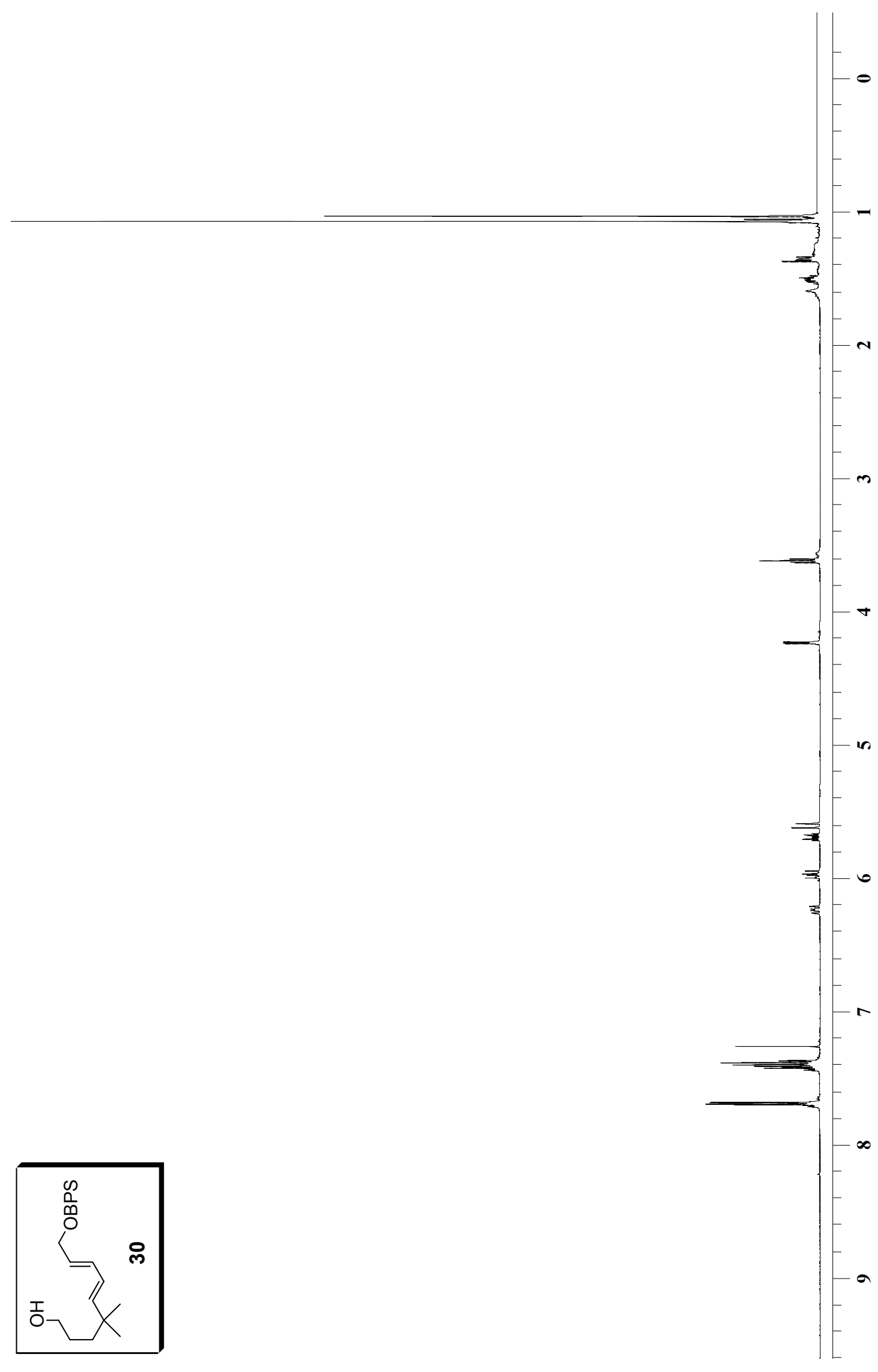




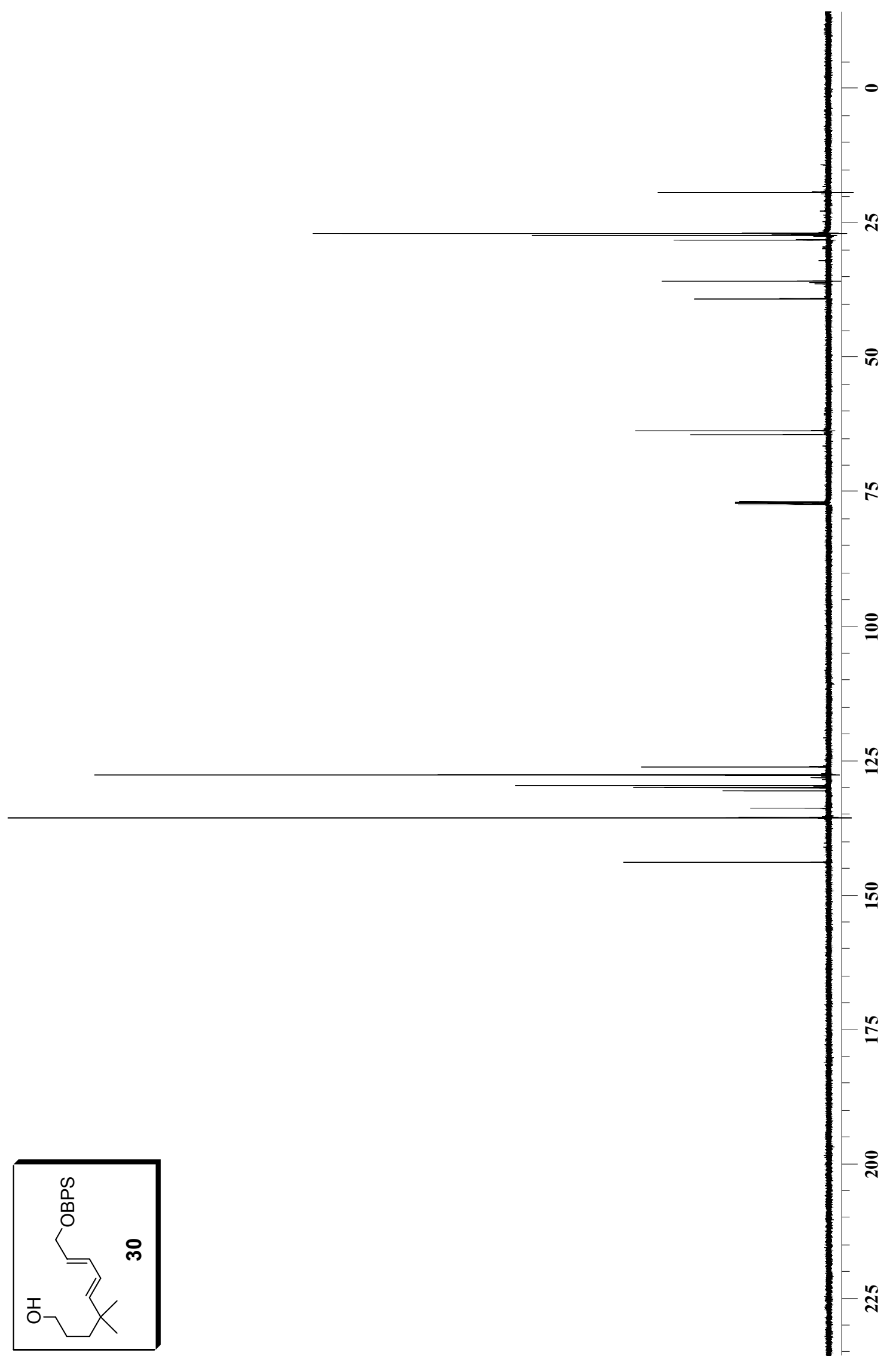




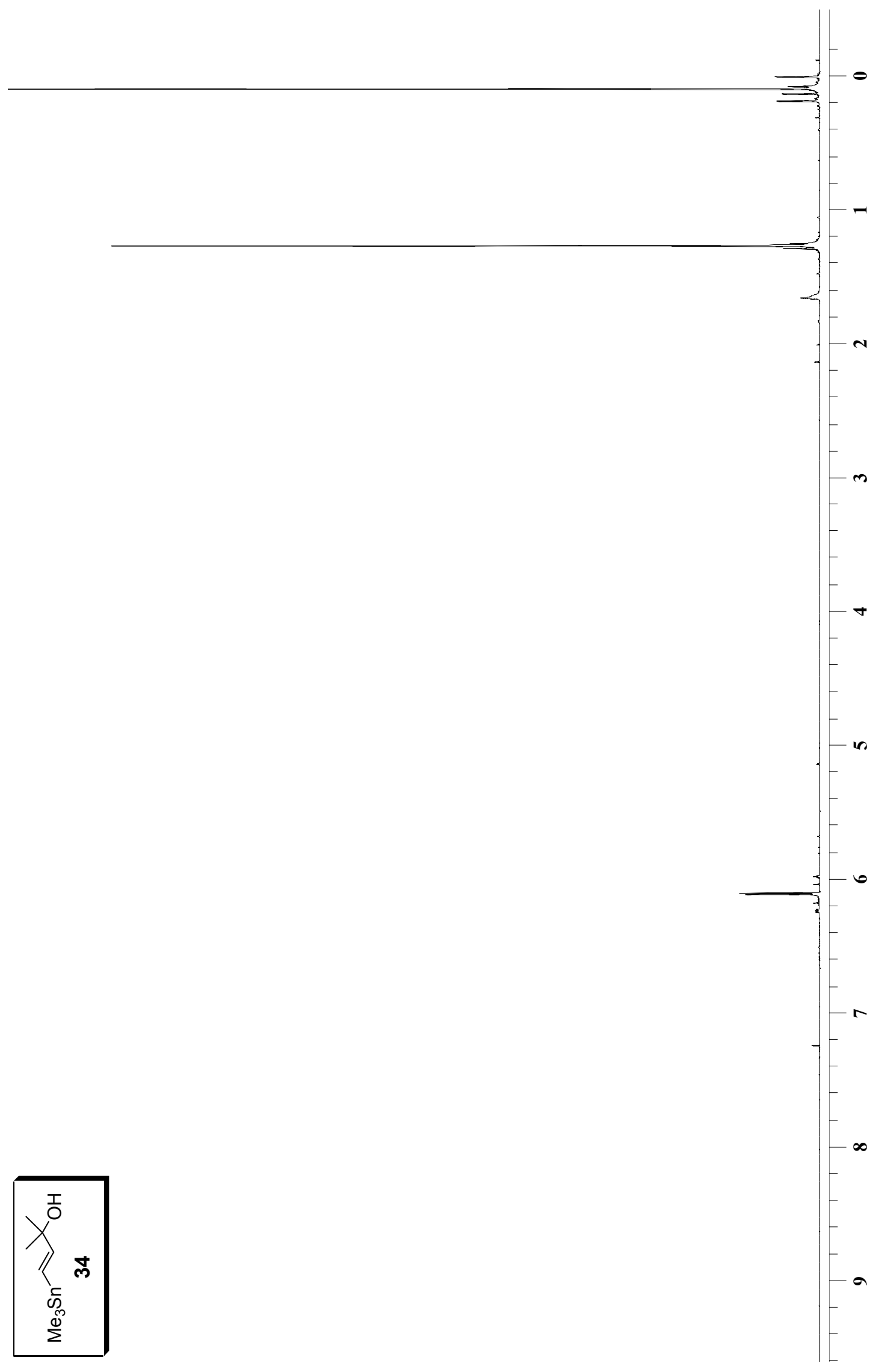




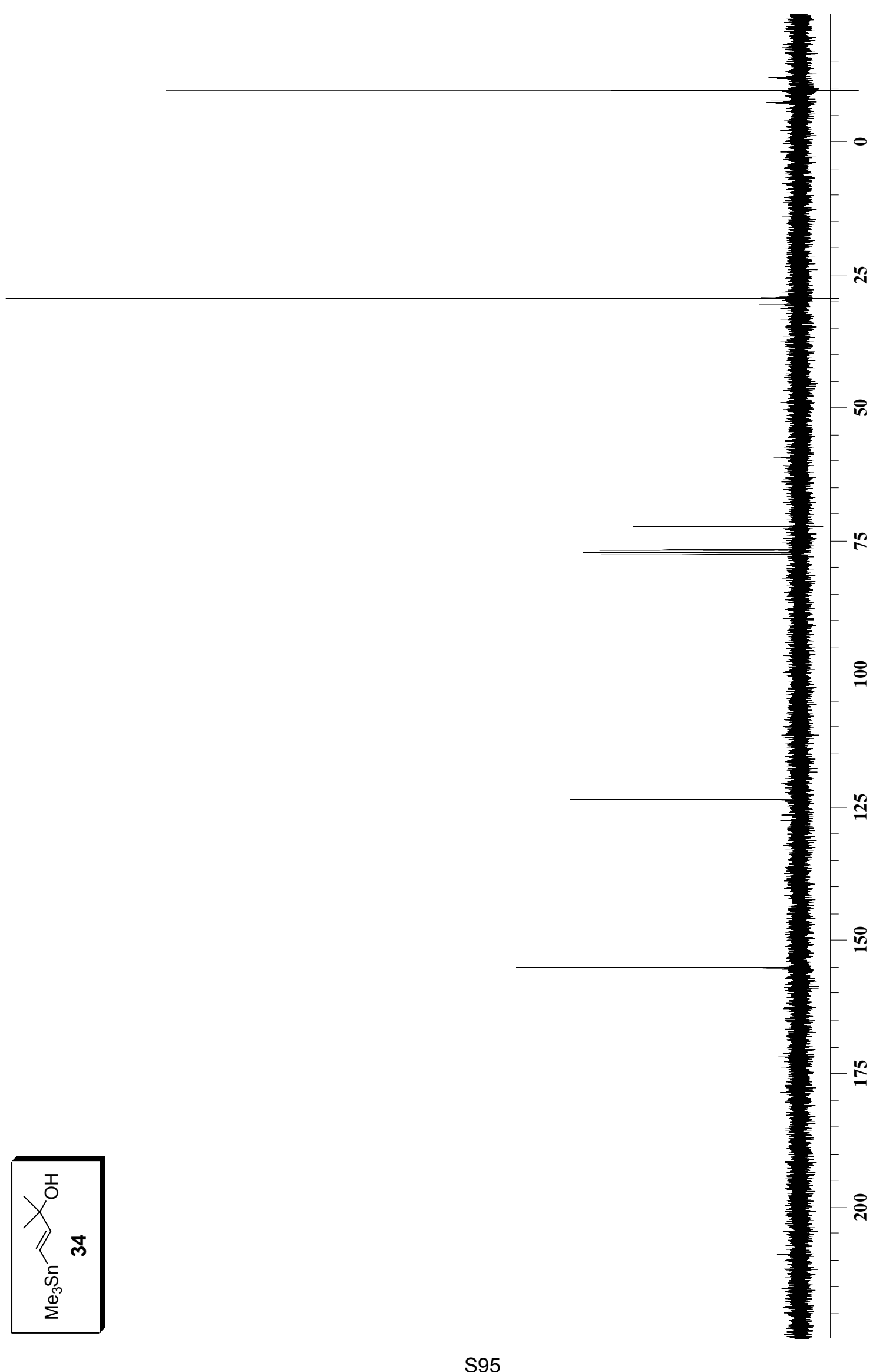




\section{References and Notes}

(1) For a prior preparation and spectroscopic data see: Marko, I. E.; Leung, C. W. J. Am. Chem. Soc. 1994, 116, 371-372.

(2) For prior preparation and spectroscopic data see: Prakash, G. K. S.; Krishnamurthy, V. V.; Olah, G. A.; Farnum, D. G. J. Am. Chem. Soc. 1985, 107, 3928-3935.

(3) For prior preparation and spectroscopic data see: Reich, H. J.; Shah, S. K.; Chow, F. J. Am. Chem. Soc. 1979, 101, 6648-6656.

(4) Desideri N.; Sestili .I; Artico M.; Massa S.; Loi, A.G; Doa M.; Musiu, C.; Lacolla, P. Med. Chem. Res. 1995, 5, 431-441.

(5) This compound was prepared as previously described: Boden, C. D. J.; Pattenden, G.; Ye, T. J. Chem. Soc., Perkin Trans. 1 1996, 2417-2419 and Maleczka, R. E., Jr.; Terrel, L. R.; Clark, D. H.; Whitehead, S. L.; Gallagher, W. P.; Terstiege, I. J. Org. Chem. 1999, 64, 5958-5965.

(6) Evans, D. A.; Barnes, D. M.; Johnson, J. S.; Lectka, T.; von Matt, P.; Miller, S.J.; Murry, J. A.; Norcross, R. D.; Shaughnessy, E. A.; Campos, K. R. J. Am. Chem. Soc. 1999, 121, 75827594.

(7) Johns, A.;Murphy, J. A.; Sherburn, M. S. Tetrahedron 1989, 45, 7835-7858.

(8) For prior preparation and spectroscopic data see: Organ, M. G.; Cooper, J. T.; Rogers, L. R.; Soleymanzadeh, F.; Paul, T. J. Org, Chem. 2000, 65, 7959-7970. 
(9) For prior preparation and spectroscopic data see: Araki, Y; Konoike, T. J.Org. Chem. 1997, 62, 5299-5309.

(10) For a prior preparation see: Lohr, Sandra; De Meijere, Armin. Synlett 2001, 489-492.

(11) For a prior preparation and spectroscopic data see: Polt, R.; Sames, D.; Chruma, J. J. Org. Chem. 1999, 64, 6147-6158.

(12) This procedure is a modification of the procedure reported by Takai: Takai, K.; Ichiguchi, T.; Hikasa, S. Synlett 1999, 1268-1270.

(13) For prior preparation and spectroscopic data see: Kabalka, G. W.; Gooch, E. E.; Hsu, H. C. Synth. Commun. 1981, 11, 247-251.

(14) For a prior preparation and spectroscopic data see: Nishimura, T.; Kakiuchi, N.; Onoue, T.; Ohe, K.; Uemura, S. J. Chem. Soc., Perkin Trans 1 2000, 11, 1915-1918.

(15) For prior preparation and spectroscopic data see: Harada, T.; Iwazaki, K.; Otani, T.; Oku, A. J. Org. Chem. 1998, 63, 9007-9012. 